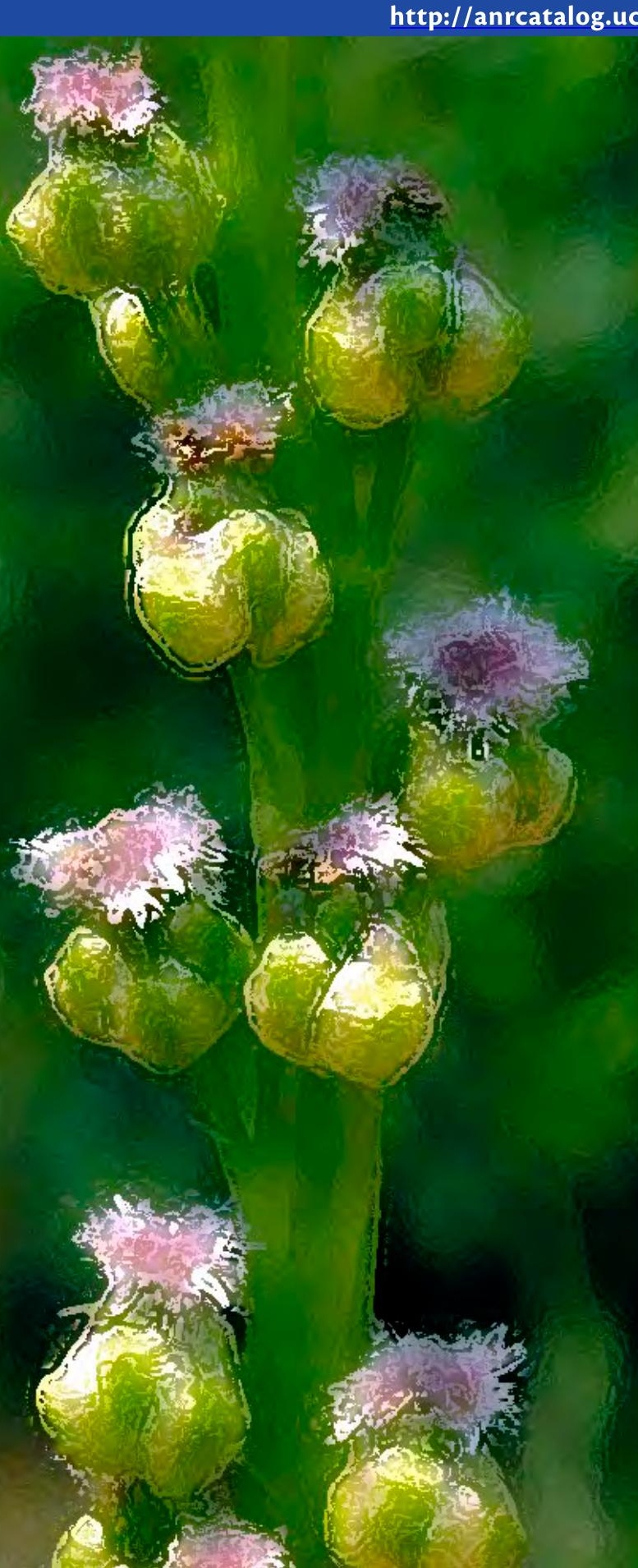

\title{
Livestock-Poisoning Plants of California
}

LARRY FORERO, University of California Cooperative Extension Livestock Advisor, Shasta and Trinity Counties; GLENN NADER, University of California Cooperative Extension Livestock and Natural Resources Advisor, Sutter-Yuba and Butte Counties; ARTHUR CRAIGMILL, University of California Cooperative Extension Environmental Toxicology Specialist, Sierra Foothill Research and Extension Center; JOSEPH M. DITOMASO, University of California Cooperative Extension Weed Specialist, Department of Plant Sciences, UC Davis; BIRGIT PUSCHNER, Professor of Veterinary Toxicology, California Animal Health and Food Safety Laboratory; and JOHN MAAS, University of California Cooperative Extension Veterinarian, School of Veterinary Medicine, UC Davis.

Poisonous plants cause significant losses of livestock every year. A successful livestock operator must know which poisonous plants occur on a given range or pasture and how they can be controlled or avoided. This publication shows which plants are poisonous, tells how they affect stock, and suggests ways to reduce losses from poisoning.

Undesirable effects may result from a single ingestion of a large amount of a poisonous plant, but some plants are so toxic that very small amounts may result in severe disease or death. Other plants cause chronic poisoning only after ingestion over weeks or months. The later situation may result in clinical signs long after the exposure to the toxic plant material, and treatment may no longer be possible.
With few exceptions, livestock will not eat poisonous plants unless forced to by hunger. The single most important way to prevent poisoning is to use proper range and pasture management practices to provide ample forage, encouraging consumption of nontoxic plants. Areas infested with poisonous plants should be avoided when trailing, holding, or unloading animals. Supplemental feed may protect stock if these conditions cannot be avoided, but there are circumstances ( for example, herbicide applications) that may change palatability or increase toxicity in some plants. If toxic weeds are embedded in alfalfa cubes or included in total mixed rations, animals may not be able to avoid ingestion of them.

Many poisonous plants may be controlled with herbicides. Often, however, the uneven distribution 


\section{Possible poisonous plant in hay or feed: What to do}

- Work with your veterinarian to determine whether the animals' clinical sign may be a result of plant exposure.

- Collect the whole plant (if practical) or representative parts of the plant, including leaves, flowers, stems, roots, and fruit, and have it identified by a trained individual (local nursery, county agricultural commissioner, $U C$ Cooperative Extension Advisor, veterinarian, diagnostic laboratory, etc.).

- Save suspect plant material or feed for possible future evaluation.

- Once plants are identified, ask your veterinarian to contact a veterinary toxicologist for detailed consultation.

- If the animal dies, submit it to a veterinary diagnostic laboratory.

of poisonous plants on a range or in a pasture makes large-scale chemical control uneconomical. However, small patches of poisonous plants can and should be eradicated to prevent them from spreading to other areas. The specifics of chemical control of poisonous plants are beyond the scope of this publication; see your county Farm Advisor or a UC Cooperative Extension Specialist, or contact a pest control adviser (PCA) for specific recommendations for your area.
Diagnosing a plant poisoning can be difficult and must be done quickly. In many cases, clinical signs are nonspecific (such as diarrhea), and postmortem lesions are not characteristic. The assistance of your veterinarian is crucial. This is especially important in insurance or legal investigations. Producers and farm managers, along with veterinarians and diagnosticians, play important roles, and all contribute information that may be important to diagnose a poisoning case. Once all the information is available, all evidence is collected, and proper sampling of specimens has occurred, a summary of findings will be instrumental in preventing recurrences.

Accurate plant identification is critical if you suspect that a particular plant is causing problems for your livestock. Producers can be most helpful by providing a grazing history, carefully observing what plants have been grazed, especially suspicious plants. The best approach is to collect the whole plant (if practical) or representative parts of the plant, including leaves, flowers, stems, roots, and fruit, and press them dry in a folded newspaper between two sheets of cardboard, or roll them up between the pages of a newspaper or magazine. The plant sample can then be taken or sent to your local UC Cooperative Extension advisor or county agricultural commissioner office for identification. Local nurseries may also be a good source for plant identification. To determine whether a particular plant is found in your area, see the Calflora Web site, http://www.calflora.org/.

\section{Livestock Poisoning by Plants in California}

The California Animal Health and Food Safety (CAHFS) Laboratory System toxicology laboratory investigated numerous cases of suspected plant poisonings from 1990 to 2007. CAHFS veterinary toxicologists have diagnosed plants as the cause of toxicosis in more than 600 submitted cases, most of these in livestock. The largest number of submissions was for cattle, followed by horses, pigs, goats, and sheep.

The most commonly diagnosed cause of plant poisoning is ornamental oleander, a nonnative species (fig. 1). The data from CAFHS are from submitted samples, so they do not necessarily represent the overall occurrence of plant poisonings in California.

\section{Possible poisonous plant in pasture: What to do}

1. Work with your veterinarian to determine whether the animal's clinical sign may be a result of plant exposure.

2. Determine whether a plant is found in your area. Visit the Calflora Web site, http://www. calflora.org/.

3. Walk the field, collecting any unusual or toxic plants, and have them identified.

4. If you cannot identify a suspect plant, take it to your county agricultural commissioner or UC Cooperative Extension office for identification.

5. If an animal dies, submit it to a veterinary diagnostic lab. 
Although most of the plants discussed in this publication are not among those that have confirmed diagnoses, it is important to know that they can be poisonous. Awareness of poisonous plants growing in a certain geographical region, the season when they are most available, and their associated clinical signs are instrumental in making a diagnosis and initiating treatment. Most important, recognition of poisonous plants in hay or forage may help prevent plant poisonings in animals.

The following tables give summary information about livestock-poisoning plants in California. For full information on plants listed, refer to the descriptions in the text.

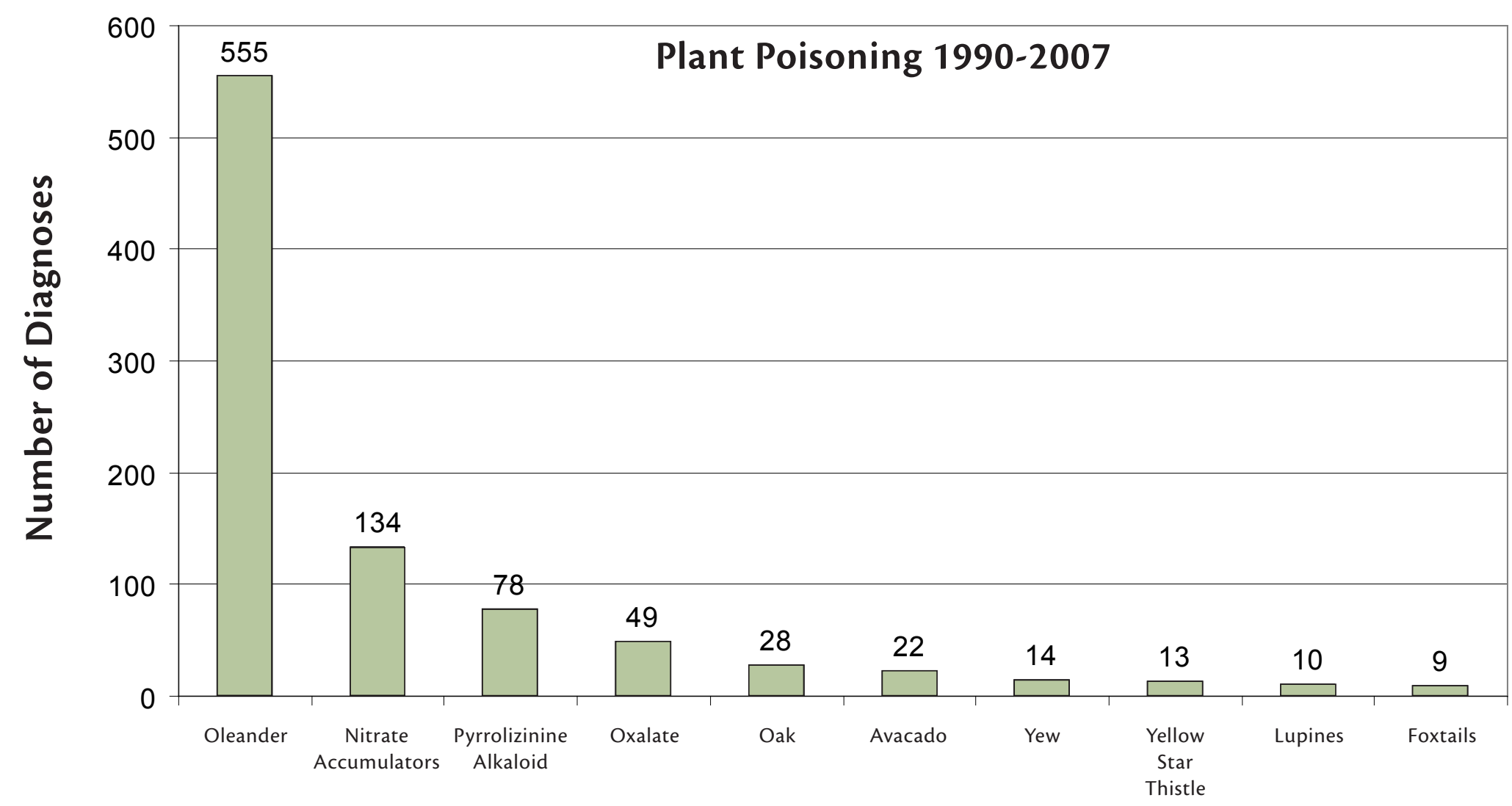

Figure 1. Sources of plant poisoning in livestock, 1990-2007. Source: CAHFS. 
Table 1. Livestock-poisoning plants commonly found in selected regions of California

\begin{tabular}{|c|c|}
\hline Common name & Scientific name \\
\hline \multicolumn{2}{|c|}{ North Coast } \\
\hline arrowgrass & Triglochin spp. \\
\hline azalea & Rhododendron spp. \\
\hline chokecherry & Prunus virginiana \\
\hline dogbane & Apocynum spp. \\
\hline fiddleneck & Amsinckia spp. \\
\hline milkweed & Asclepias spp. \\
\hline ragweed or ragwort & Senecio spp. \\
\hline rhododendrum & Rhododendron spp. \\
\hline ryegrass, perennial & Lolium spp. \\
\hline tansy ragwort & Senecio spp. \\
\hline veratrum (false hellebore) & Veratrum californicum \\
\hline water hemlock & Cicuta douglasii, C. maculata \\
\hline \multicolumn{2}{|c|}{ South Coast } \\
\hline arrowgrass & Triglochin spp. \\
\hline chokecherry & Prunus virginiana \\
\hline dogbane & Apocynum spp. \\
\hline fiddleneck & Amsinckia spp. \\
\hline locoweed & Astragalus spp. \\
\hline milkweed & Asclepias spp. \\
\hline tree tobacco & Nicotiana spp. \\
\hline \multicolumn{2}{|c|}{ Sacramento Valley } \\
\hline cocklebur & Xanthium spinosum, X. strumarium \\
\hline curly dock & Rumex crispus \\
\hline dogbane & Apocynum spp. \\
\hline fiddleneck & Amsinckia spp. \\
\hline foxtail & Hordeum spp. and Setaria spp. \\
\hline groundsel & Senecio spp. \\
\hline milkweed & Asclepias spp. \\
\hline oak & Quercus spp. \\
\hline oleander & Nerium spp. \\
\hline ragweed or ragwort & Senecio spp. \\
\hline starthistle & Centaurea spp. \\
\hline tree tobacco & Nicotiana spp. \\
\hline water hemlock & Cicuta douglasii, C. maculata \\
\hline \multicolumn{2}{|c|}{ San Joaquin Valley } \\
\hline cocklebur & Xanthium spinosum, X. strumarium \\
\hline curly dock & Rumex crispus \\
\hline fiddleneck & Amsinckia spp. \\
\hline foxtail & Hordeum spp. and Setaria spp. \\
\hline groundsel & Senecio spp. \\
\hline locoweed & Astragalus spp. \\
\hline milkweed & Asclepias spp. \\
\hline oak & Quercus spp. \\
\hline oleander & Nerium spp. \\
\hline ragweed or ragwort & Senecio spp. \\
\hline
\end{tabular}

\section{Common name}

starthistle

tree tobacco

water hemlock

\begin{tabular}{l|l|l}
\multicolumn{2}{c}{ Sierra Foothills } \\
\hline cocklebur & Xanthium spinosum, X. strumarium
\end{tabular}

deathcamas

dogbane

foxtail

klamathweed

larkspur (low)

milkweed

oak

ragweed or ragwort

toyon

tree tobacco

western azalea

\begin{tabular}{|l|l|}
\hline & Sierra Nevada Northern Range \\
\hline chokecherry & Prunus virginiana \\
dogbane & Apocynum spp. \\
lupine & Lupinus spp. \\
Ponderosa pine & Pinus ponderosa \\
\hline
\end{tabular}

\section{chokecherry}

deathcamas

dogbane

larkspur (tall)

Ponderosa pine

ragwort or ragwort

toyon

veratrum (false hellebore)

water hemlock

western azalea

western bracken fern

\section{deathcamas}

greasewood

horsetail and scouring rushes

Ponderosa pine

ragweed or ragwort

summer pheasant's eye

\section{avocado}

chokecherry

locoweed

ragweed or ragwort

tree tobacco
Scientific name

\section{Centaurea spp.}

Nicotiana spp.

Cicuta douglasii C. maculata

Zigadenus spp.

Apocynum spp.

Hordeum spp. and Setaria spp.

Hypericum perforatum

Delphinium spp.

Asclepias spp.

Quercus spp.

Senecio spp.

Heteromeles arbutifolia

Nicotiana spp.

Rhododendron spp.

Sierra Nevada Central Range

\section{Prunus virginiana}

Zigadenus spp.

Apocynum spp.

Delphinium spp.

Pinus ponderosa

Senecio spp.

Heteromeles arbutifolia

Veratrum californicum

Cicuta douglasii, C. maculata

Rhododendron spp

Pteridium aquilinum

East of the Sierra Nevada

\section{Zigadenus spp.}

Sarcobatus vermiculatus

Equisetum spp.

Pinus ponderosa

Senecio spp.

Adonis aestivalis

Southern California

Persea americana
Prunus virginiana
Astragalus spp.
Senecio spp.
Nicotiana spp.


Table 2. Most commonly diagnosed plant poisonings for selected livestock, in descending order of occurrence

\begin{tabular}{|l|l|l|l|}
\hline Cattle & Sheep & Horses & Goats \\
oleander & oleander & oleander & avocado \\
nitrate/nitrite* & pyralate & pyrrolizidine alkaloids & \\
oxalate & nitrate/nitrite & yellow starthistle & nitrate/nitrite \\
pyrrolizidine alkaloids & dupine & dogbane & lupine \\
oak & perennial ryegrass & foxtail & oleander \\
\hline
\end{tabular}

Source: CAHFS,

Notes:

*Nitrate/nitrite: Present in johnsongrass (Sorghum halapense) and sudangrass (S.bicolor); oat hay and other grass hays; lambsquarters and goosefoot (Chenopodium spp.); and pigweed (Amaranthus spp.).

${ }^{\natural}$ Pyrrolizidine alkaloids: Present in fiddleneck (Amsinckia spp.), tansy ragwort (Senecio jacobaea), and groundsel (Senecio spp.).

FOxalate: Present in greasewood (Sarcobatus vermiculatus); sorrel (Oxalis spp.); dock (Rumex spp.); pigweed (Amaranthus spp.); and lambsquarter and goosefoot (Chenopodium spp.).

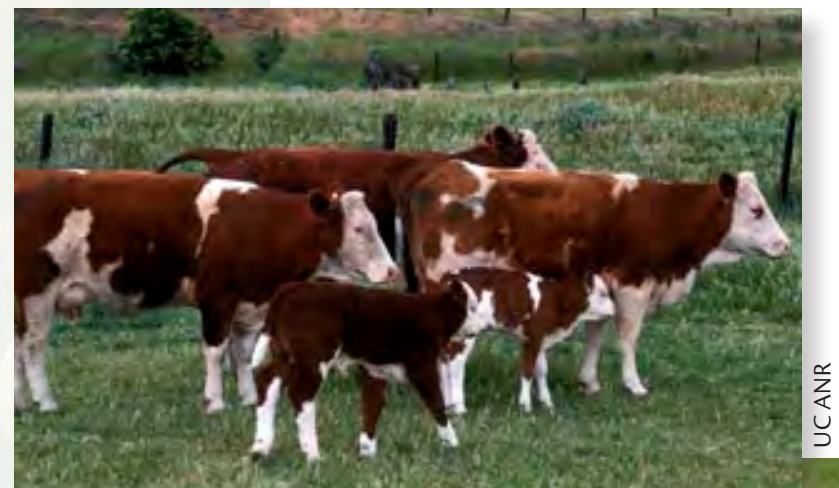

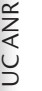
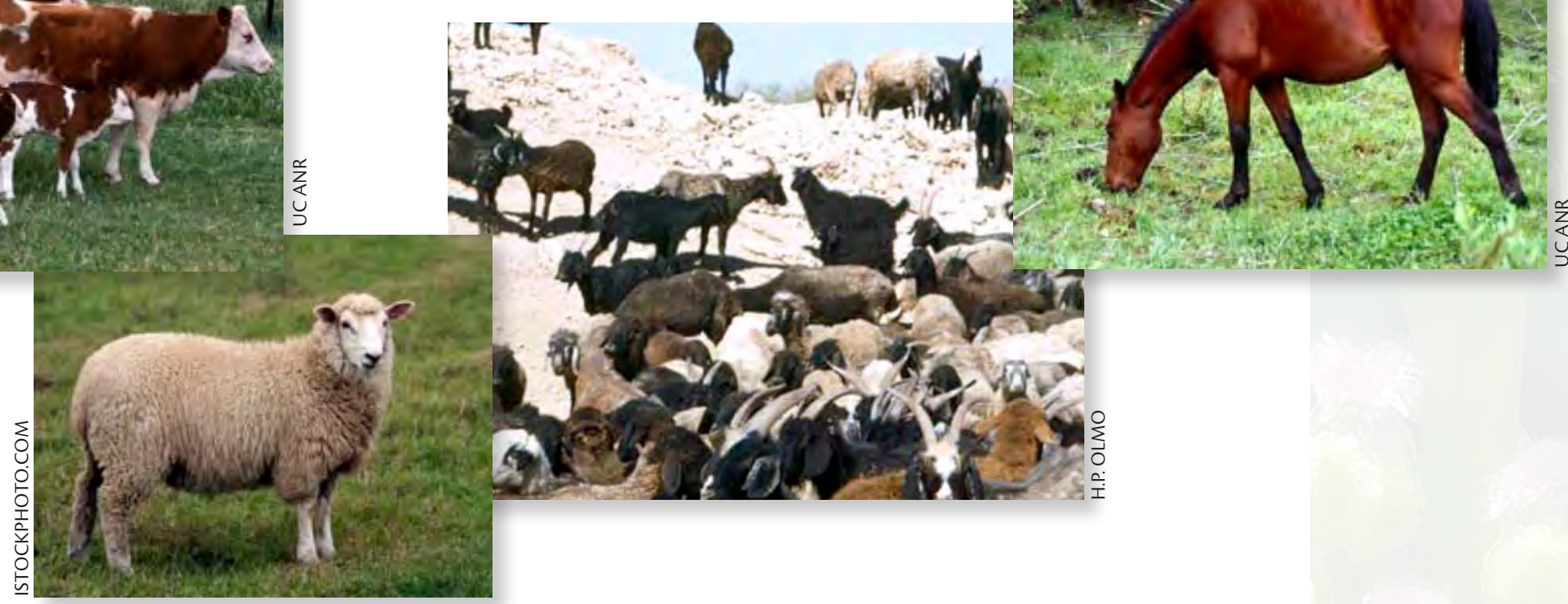
Table 3. Toxic dosage for selected livestock-poisoning plants in California

\begin{tabular}{|c|c|c|c|c|}
\hline \multirow{2}{*}{ Plant } & \multicolumn{4}{|r|}{ Toxic dosage } \\
\hline & Cattle & Sheep & Horses & Comments \\
\hline arrowgrass & $1.5 \% \mathrm{bw}$ & $5-2 \%$ bw & no data & Flowering spikes have twice the amount of toxin and require one-half the dosage. \\
\hline avocado & no data & $5.5-20 \mathrm{~g} / \mathrm{kg} \mathrm{bw}$ & no data & $\begin{array}{l}\text { The toxic dose range in sheep and goats for fresh leaves, chronic (low dose) and acute (high dose). } \\
\text { Cattle and horses are also affected. }\end{array}$ \\
\hline \multirow[t]{2}{*}{ cocklebur } & $1 \% \mathrm{bw}$ & $1.5 \%$ bw & no data & Consumption of fresh green sprouts. \\
\hline & $0.75 \%$ bw & no data & no data & Consumption of germinating plants (lethal). \\
\hline deathcamas & $1 \% \mathrm{bw}$ & no data & no data & Consumption of green plant (lethal). \\
\hline dogbane & no data & no data & no data & No conclusive toxic dosage information available. \\
\hline foxtail & no data & no data & no data & Mechanical injury. \\
\hline greasewood & $2.5 \mathrm{~kg} / 45 \mathrm{~kg}$ bw & $2.5 \mathrm{~kg} / 45 \mathrm{~kg}$ bw & no data & Toxic if eaten quickly. \\
\hline groundsel and ragwort & $5-10 \% \mathrm{bw}^{\ddagger}$ & no data & $3-7 \%$ bw & Requires a total intake of 25 to $50 \%$ bw over several months \\
\hline klamathweed & $1 \% \mathrm{bw}^{*}$ & $0.7-0.9 \mathrm{~kg}$ & no data & Toxic concentrations vary by plant phenology and location. \\
\hline locoweed & $30-50 \%$ bw in dw & no data & $81 \mathrm{lb}^{\dagger}$ & Symptoms appear 2 to 9 weeks after consumption. \\
\hline lupine & no data & no data & no data & Depends on lupine species, plant phenology, time of consumption, and species of animal. \\
\hline oak & no data & no data & no data & Depends on oak species, plant phenology, time of consumption, and species of animal. \\
\hline oleander & 5 leaves & 5 leaves & 20-30 g leaves & Both green and dried leaves are toxic. \\
\hline pine needles & $2.2-2.7 \mathrm{~kg}$ & no data & no data & Consumption per day for more than 3 days (abortion). \\
\hline poison hemlock & $0.2-0.5 \%$ bw & $0.6-0.8 \%$ bw & no data & Seed heads are more toxic than other plant parts. \\
\hline tobacco & $2 \%$ bw & no data & no data & Consumption of this level of fresh plant is lethal. \\
\hline water hemlock & $1-12 \mathrm{oz}$ & $2 \mathrm{oz}$ & $8 \mathrm{oz}$ & Consumption of roots. \\
\hline western bracken fern & no data & no data & $3-5 \%$ bw & Consumption for at least 30 days. \\
\hline yellow starthistle & no data & no data & $600 \mathrm{lb} \mathrm{dm}$ & Consumption over 1 to 3 months. Not generally considered toxic to cattle and sheep. \\
\hline $\begin{array}{l}\text { Milkweed } \\
\text { common name }\end{array}$ & \multicolumn{2}{|c|}{ Asclepias species name } & \multicolumn{2}{|c|}{ Estimated toxic dosage for sheep, cattle, and horses } \\
\hline antelope horns & \multicolumn{2}{|l|}{ A. asperula } & \multicolumn{2}{|l|}{$>1 \%$ bw } \\
\hline broadleaf & \multicolumn{2}{|l|}{ A. latifolia } & \multicolumn{2}{|l|}{$0.2-0.4 \%$ bw } \\
\hline Indian & \multicolumn{2}{|l|}{ A. eriocarpa } & \multicolumn{2}{|l|}{$0.2 \% \mathrm{bw}$} \\
\hline narrow-leaved & \multicolumn{2}{|l|}{ A. fascicularis } & \multicolumn{2}{|l|}{$0.5-1 \%$ bw } \\
\hline showy & \multicolumn{2}{|l|}{ A. speciosa } & \multicolumn{2}{|l|}{$1-2 \%$ bw } \\
\hline
\end{tabular}

Source: Adapted from Burrows and Tyrl 2001.

Notes:

bw = body weight

$\mathrm{dm}=$ dry matter

*500- to 700-pound calves.

${ }^{\dagger}$ Consumed over 4 to 6 weeks.

¥This level consumed in a few days or weeks causes acute liver disease. 
Table 4. Signs of poisoning and plants commonly responsible

\begin{tabular}{|c|c|c|c|}
\hline Plant & Toxin & $\begin{array}{l}\text { Organ or } \\
\text { systems affected }\end{array}$ & Signs \\
\hline arrowgrass & cyanide & blood, all organs & sudden death, salivation, heavy breathing \\
\hline chokecherry & cyanide & cell poison, all organs & sudden death, salivation, heavy breathing \\
\hline cocklebur & glycosides & cell poison, all organs & sudden death, weakness, inappetance, incoordination, muscle spasms, convulsions, coma \\
\hline curly dock & oxalates, nitrate & kidney, blood & sudden death, salivation, depression, incoordination, muscle tremors, weakness, coma \\
\hline deathcamas & alkaloids & nervous & sudden death, excessive salivation, lowered temperature, staggering, weakness, coma \\
\hline dogbane/Indian hemp & cardiac glycosides & heart & sudden death, diarrhea, weakness, irregular heartbeat \\
\hline fiddleneck & pyrrolizidine & liver & chronic: appetite loss, weight loss, appetite loss, rectal straining \\
\hline foxtails & physical & mouth, eyes, skin & ulceration and lesions in mouth, tongue, gums, eyes \\
\hline greasewood & oxalates & kidney & sudden death, depression, incoordination, weakness, coma \\
\hline groundsel & pyrrolizidine & liver & chronic: appetite loss, weight loss, rectal straining \\
\hline horsetail & thiaminase & nervous & thiamine deficiency, depression, unsteady gait, incoordination, weakness, seizures, and diarrhea \\
\hline klamathweed & hypericin & skin & photosensitization; sunburn of lips, mouth, and unpigmented skin; blistering, loss of condition \\
\hline larkspur (tall) & alkaloids & nervous & sudden death, tremors, weakness, incoordination, staggering, slobbering, bloat \\
\hline locoweed & alkaloids & nervous & difficulty eating, exaggerated mouth movement, excitability; depression, weakness, weight loss, incoordination \\
\hline lupine & alkaloids & nervous, reproductive & birth defects, abortion, tremors, incoordination, head pressing, seizures \\
\hline milkweed & cardiac glycosides & $\begin{array}{l}\text { gastrointestinal, heart, } \\
\text { nervous }\end{array}$ & depression, diarrhea, colic, irregular respiration \\
\hline nightshades & alkaloids & gastrointestinal & gastrointestinal upset, constipation or diarrhea, drowsiness, salivation, weakness \\
\hline oak & tannins & liver, kidney & sudden death, bloody diarrhea, kidney failure \\
\hline oleander & cardiac glycosides & heart & sudden death, depression, salivation, weakness, irregular heartbeat, diarrhea \\
\hline poison hemlock & coniine (alkaloids) & nervous, reproductive & nervousness, trembling, weakness, coma, birth defects \\
\hline Ponderosa pine & isocupressic acid & reproductive & abortion, incoodrination, aimless wander, congenital defects \\
\hline ryegrass & alkaloids (ergot) & nervous & incoordination, staggering \\
\hline summer pheasant's eye & glycosides & gastrointestinal & gastrointestinal disturbance, diarrhea, decreased gut motility, sudden death \\
\hline tobacco & alkaloids (nicotine) & nervous, reproductive & birth defects, abortion, weakness, staggering \\
\hline toyon & cyanide & cell poison, all organs & sudden death \\
\hline veratrum & alkaloids & nervous, reproductive & birth defects, abortion; labored breathing, salivation, convulsions \\
\hline water hemlock & alcohols & nervous & sudden death, muscle spasms, teeth grinding, severe convulsions \\
\hline western bracken fern & glycosides & bone marrow, bladder & $\begin{array}{l}\text { bone marrow depression signs; hemmorhage, bloody feces, bloody nasal secretions; } \\
\text { bladder tumors; pink, red, brown urine }\end{array}$ \\
\hline
\end{tabular}

Note: The signs listed in this table are commonly seen after the specific plant intoxications. However, other signs may predominate depending on the dosage, duration of exposure, and environmental factors. Diagnosis must be done by a licensed veterinarian and may require toxiciological analysis by a diagnostic laboratory to confirm the plant involved. Primary or usual signs are given in bold. 


\section{Table 4. Continued}

\begin{tabular}{|c|c|c|c|}
\hline Plant & Toxin & $\begin{array}{l}\text { Organ or } \\
\text { systems affected }\end{array}$ & SHEEP \\
\hline arrowgrass & cyanide & blood, all organs & sudden death, salivation, heavy breathing \\
\hline chokecherry & cyanide & cell poison, all organs & sudden death, salivation, heavy breathing \\
\hline cocklebur & glycosides & cell poison, all organs & sudden death, weakness, inappetance, incoordination, muscle spasms, convulsions, coma \\
\hline curly dock & oxalates, nitrate & kidney, blood & sudden death, salivation, depression, incoordination, muscle tremors, weakness, coma \\
\hline deathcamas & alkaloids & nervous & sudden death, excessive salivation, lowered temperature, staggering, weakness, coma \\
\hline dogbane/Indian hemp & cardiac glycosides & heart & sudden death, diarrhea, weakness, irregular heartbeat \\
\hline fiddleneck & pyrrolizidine & liver & $\begin{array}{l}\text { weight loss, appetite loss [sheep are more resistant to poisoning by the pyrrolizidine alkaloids than cattle or } \\
\text { horses, but may be affected by large amounts] }\end{array}$ \\
\hline foxtails & physical & mouth, eyes, skin & ulceration and lesions in mouth, tongue, gums, eyes \\
\hline greasewood & oxalates & kidney & sudden death, depression, incoordination, weakness, coma \\
\hline groundsel & pyrrolizidine & liver & weight loss, appetite loss \\
\hline horsetail & thiaminase & nervous & thiamine deficiency, depression, unsteady gait, incoordination, weakness, seizures; diarrhea in cattle \\
\hline klamathweed & hypericin & skin & photosensitization, sunburn of lips, mouth and unpigmented skin, blistering, loss of condition \\
\hline larkspur (tall) & alkaloids & nervous & tremors, weakness, incoordination, staggering, slobbering, bloat \\
\hline locoweed & alkaloids & nervous & depression, weakness, weight loss, incoordination \\
\hline lupine & alkaloids & nervous, reproductive & birth defects, abortion, tremors, incoordination, head pressing, seizures \\
\hline milkweed & cardiac glycosides & $\begin{array}{l}\text { gastrointestinal, heart, } \\
\text { nervous }\end{array}$ & depression, diarrhea, colic, irregular respiration \\
\hline nightshades & alkaloids & gastrointestinal & gastrointestinal upset, constipation or diarrhea, drowsiness, salivation, weakness \\
\hline oak & tannins & liver, kidney & sudden death, bloody diarrhea, kidney failure \\
\hline oleander & cardiac glycosides & heart & sudden death, depression, salivation, weakness, irregular heartbeat, diarrhea \\
\hline poison hemlock & coniine (alkaloids) & nervous, reproductive & nervousness, trembling, weakness, coma, birth defects \\
\hline Ponderosa pine & isocupressic acid & reproductive & abortion, incoodrination, aimless wander, congenital defects \\
\hline ryegrass & alkaloids (ergot) & nervous & incoordination, staggering \\
\hline \multirow{3}{*}{$\begin{array}{l}\text { starthistle } \\
\text { summer pheasant's } \\
\text { eye } \\
\text { tobacco }\end{array}$} & lactones & nervous & weight loss, abnormal curling of lips (chewing disease), yawning \\
\hline & glycosides & gastrointestinal & gastrointestinal disturbance, diarrhea, decreased gut motility, sudden death \\
\hline & alkaloids (nicotine) & nervous, reproductive & birth defects, abortion, weakness, staggering \\
\hline toyon & cyanide & cell poison, all organs & sudden death, salivation, heavy breathing \\
\hline veratrum & alkaloids & nervous, reproductive & birth defects, abortion; labored breathing, salivation, convulsions \\
\hline water hemlock & alcohols & nervous & sudden death, muscle spasms, teeth grinding, severe convulsions \\
\hline
\end{tabular}

Note: The signs listed in this table are commonly seen after the specific plant intoxications. However, other signs may predominate depending on the dosage, duration of exposure, and environmental factors. Diagnosis must be done by a licensed veterinarian and may require toxiciological analysis by a diagnostic laboratory to confirm the plant involved. Primary or usual signs are given in bold. 


\section{Table 4. Continued}

\begin{tabular}{|c|c|c|c|}
\hline Plant & Toxin & $\begin{array}{l}\text { Organ or } \\
\text { systems affected }\end{array}$ & Signs \\
\hline arrowgrass & cyanide & blood, all organs & sudden death, salivation, heavy breathing \\
\hline avocado & persin & vascular & mastitis (abrupt cessation of milk flow), heart failure \\
\hline chokecherry & cyanide & cell poison, all organs & sudden death, salivation, heavy breathing \\
\hline cocklebur & glycosides & cell poison, all organs & sudden death, weakness, inappetance, incoordination, muscle spasms, convulsions, coma \\
\hline curly dock & oxalates, nitrate & kidney, blood & sudden death, salivation, depression, incoordination, muscle tremors, weakness, coma \\
\hline deathcamas & alkaloids & nervous & sudden death, excessive salivation, lowered temperature, staggering, weakness, coma \\
\hline dogbane/Indian hemp & cardiac glycosides & heart & sudden death, diarrhea, weakness, irregular heartbeat \\
\hline fiddleneck & pyrrolizidine & liver & chronic: appetite loss, weight loss; walkabout disease, head pressing, rectal straining \\
\hline foxtails & physical & mouth, eyes, skin & ulceration and lesions in mouth, tongue, gums, eyes \\
\hline greasewood & oxalates & kidney & sudden death, depression, incoordination, weakness, coma \\
\hline groundsel & pyrrolizidine & liver & chronic: appetite loss, weight loss; walkabout disease, head pressing, rectal straining \\
\hline horsetail & thiaminase & nervous & thiamine deficiency, depression, unsteady gait, incoordination, weakness, seizures \\
\hline locoweed & alkaloids & nervous & depression, stiff gait, incoordination, staring, excitability; difficulty eating, exaggerated mouth movement \\
\hline milkweed & cardiac glycosides & $\begin{array}{l}\text { gastrointestinal, heart, } \\
\text { nervous }\end{array}$ & depression, incoordination, trembling, seizures \\
\hline nightshade & alkaloids & gastrointestinal & gastrointestinal upset, constipation or diarrhea, drowsiness, salivation, weakness \\
\hline oleander & cardiac glycosides & heart & sudden death, depression, salivation, weakness, irregular heartbeat, diarrhea \\
\hline poison hemlock & coniine (alkaloids) & nervous, reproductive & sudden death, nervousness, trembling, weakness, coma, birth defects \\
\hline starthistle & lactones & nervous & weight loss, abnormal curling of lips (chewing disease), yawning \\
\hline $\begin{array}{l}\text { summer pheasant's } \\
\text { eye }\end{array}$ & glycosides & gastrointestinal & gastrointestinal disturbance, diarrhea, decreased gut motility, sudden death \\
\hline toyon & cyanide & cell poison, all organs & sudden death \\
\hline water hemlock & alcohols & nervous & sudden death, muscle spasms, teeth grinding, severe convulsions \\
\hline western bracken fern & glycosides & bone marrow, bladder & thiamine deficiency, depression, unsteady gait, incoordination, weakness, seizures \\
\hline
\end{tabular}

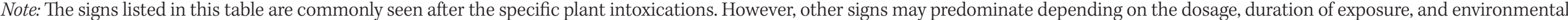

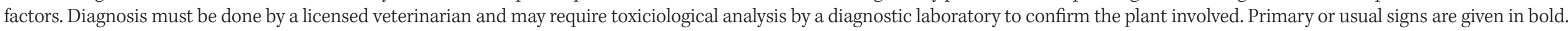




\section{Table 4. Continued}

\begin{tabular}{|c|c|c|c|}
\hline Plant & Toxin & $\begin{array}{l}\text { Organ or } \\
\text { systems affected }\end{array}$ & Signs \\
\hline arrowgrass & cyanide & blood, all organs & sudden death, salivation, heavy breathing \\
\hline avocado & persin & vascular & mastitis (abrupt cessation of milk flow), heart failure \\
\hline chokecherry & cyanide & cell poison, all organs & sudden death, salivation, heavy breathing \\
\hline cocklebur & glycosides & cell poison, all organs & sudden death, weakness, inappetance, incoordination, muscle spasms, convulsions, coma \\
\hline deathcamas & alkaloids & nervous & sudden death, excessive salivation, lowered temperature, staggering, weakness, coma \\
\hline fiddleneck & pyrrolizidine & liver & chronic: appetite loss, weight loss \\
\hline foxtails & physical & mouth, eyes, skin & ulceration and lesions in mouth, tongue, gums, eyes \\
\hline greasewood & oxalates & kidney & sudden death, depression, incoordination, weakness, coma \\
\hline groundsel & pyrrolizidine & liver & chronic: appetite loss, weight loss \\
\hline dogbane/Indian hemp & cardiac glycosides & heart & sudden death, diarrhea, weakness, irregular heartbeat \\
\hline klamathweed & hypericin & skin & photosensitization, sunburn of lips, mouth and unpigmented skin, blistering, loss of condition \\
\hline locoweed & alkaloids & nervous & difficulty eating, exaggerated mouth movement, excitability \\
\hline lupine & alkaloids & nervous, reproductive & birth defects, abortion, tremors, incoordination, head pressing, seizures \\
\hline milkweed & cardiac glycosides & $\begin{array}{l}\text { gastrointestinal, heart, } \\
\text { nervous }\end{array}$ & $\begin{array}{l}\text { Profound depression and weakness accompanied by staggering; labored respiration, elevated temperatures, } \\
\text { dilation of pupils, seizures }\end{array}$ \\
\hline nightshades & alkaloids & gastrointestinal & gastrointestinal upset, constipation or diarrhea, drowsiness, salivation, weakness \\
\hline oak & tannins & liver, kidney & sudden death, bloody diarrhea, kidney failure \\
\hline oleander & cardiac glycosides & heart & sudden death, depression, salivation, weakness, irregular heartbeat, diarrhea \\
\hline poison hemlock & coniine (alkaloids) & nervous, reproductive & nervousness, trembling, weakness, coma, birth defects \\
\hline ryegrass & alkaloids (ergot) & nervous & incoordination, staggering \\
\hline larkspur (tall) & alkaloids & nervous & tremors, weakness, incoordination, staggering, slobbering, bloat \\
\hline toyon & cyanide & cell poison, all organs & sudden death, salivation, heavy breathing \\
\hline water hemlock & alcohols & nervous & sudden death, muscle spasms, teeth grinding, severe convulsions \\
\hline
\end{tabular}

Note: The signs listed in this table are commonly seen after the specific plant intoxications. However, other signs may predominate depending on the dosage, duration of exposure, and environmental factors. Diagnosis must be done by a licensed veterinarian and may require toxiciological analysis by a diagnostic laboratory to confirm the plant involved. Primary or usual signs are given in bold. 


\section{Poisonous Ornamental Plants}

Planting of toxic ornamentals in or near pasture or livestock facilities can cause poisonings. Unknowing neighbors who dispose of yard trimmings from toxic plants by feeding them to animals or throwing them over the fence on rangelands can also cause intoxications. Avocado and oleander are the primary plants of concern.

\section{Avocado (Persea americana)}

The two most common varieties of avocados in North America are the Mexican and Guatemalan varieties. The leaves of some Guatemalan avocados have been shown to be toxic to livestock, particularly goats and horses. There is one well-documented report of avocado fruits being toxic to pet birds. To avoid the possibility of poisoning, do not feed avocado leaves and cuttings to livestock.

\section{Signs of poisoning and treatment}

Ingestion of about 1 ounce per pound of body weight of fresh Guatemalan avocado leaves (Reed variety) by lactating goats can result in noninfectious mastitis and abrupt cessation of milk production due to destruction of the milk-producing cells. Higher doses may result in death from heart failure. In horses, heart failure may be seen at higher doses. Treatment is symptomatic, as there are no known antidotes. Milk production usually does not return to normal after resolution of the mastitis.

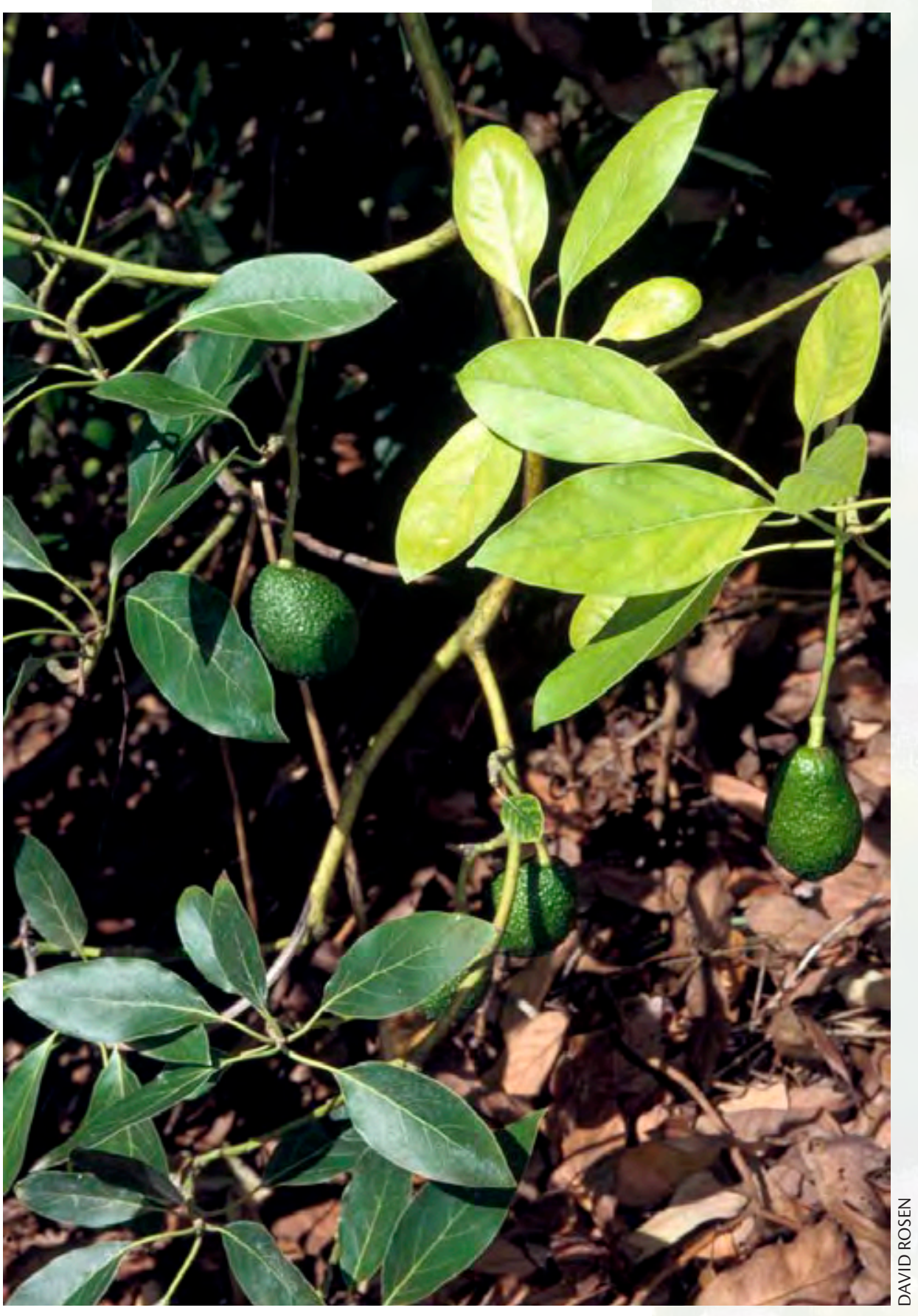

Avocado (Persea americana) leaves and fruit. 


\section{Oleander (Nerium oleander)}

This common ornamental shrub is a major cause of animal poisonings. The primary cause of oleander poisoning is plant trimmings. Oleander is planted extensively because of its resistance to drought and insects. The leaves are lance-shaped, thick, and leathery, and grow opposite each other, often in whorls. They are 8 to 10 inches long, although smaller specimens have shorter leaves. Flowers are showy, approximately 1 to 3 inches in diameter, and grow in large clusters at the ends of the branches. They can be white or any shade of pink or red all summer. The fruit is a brown podlike structure with many small seeds.

Oleander is not readily eaten, but poisoning of horses and other livestock has resulted from access to trimmings or when leaves are baled with hay. Bored horses might chew on plants that grow near their paddocks.

\section{Signs of poisoning and treatment}

The oleander toxins affect primarily the cardiovascular system. They are present in all parts of the plant, and toxicity is retained when the plant is dried. The leaves and flowers are the most toxic: 5 to 10 medium-sized leaves can be lethal to a horse or a cow. Clinical signs of oleander poisoning include diarrhea, excess salivation, depression, and anorexia. As the disease progresses, the animals develop a variety of cardiac signs, including slow and irregular heartbeat. Animals may also have tremors and difficulty breathing. Poisoning may progress so rapidly that the animal may be found dead. Treatment by a veterinarian can be successful if started as early as possible.

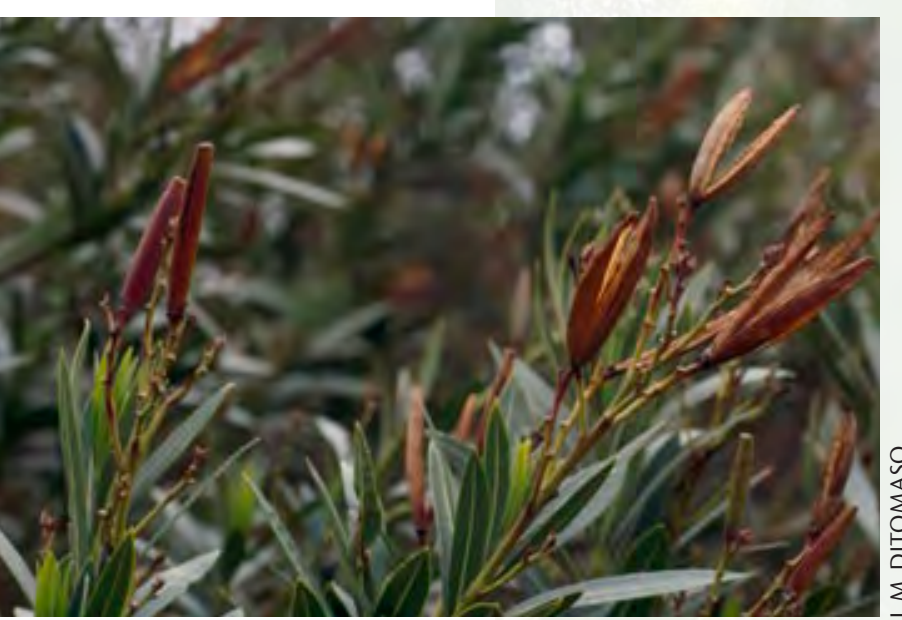

Oleander (Nerium oleander) seed pods.

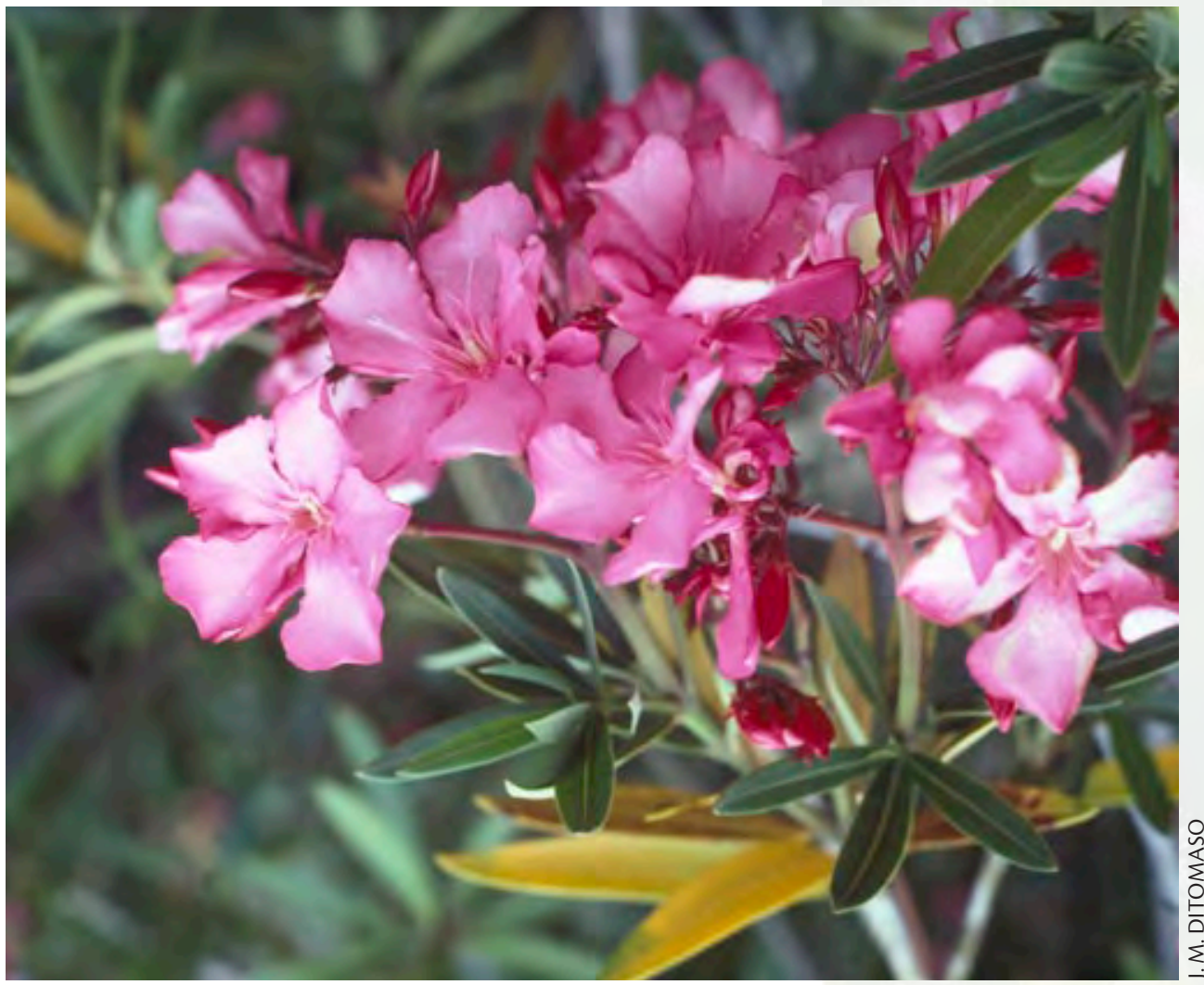

Oleander (Nerium oleander) flowers. 


\section{Other Poisonous Ornamental Plants}

The book Toxicity of Ornamental Plants to Domestic Animals and Livestock (Philips et al. 1997) contains lists of plants that should not be planted around animals to prevent poisonings. These lists have been combined in tables 5 through 7 , below.

Table 5. Deciduous trees that should not be planted around livestock and horses

\begin{tabular}{|c|c|}
\hline Common name & Scientific name \\
\hline black locust & Robinia pseudoacacia \\
\hline buckeye, horsechestnut & Aesculus spp. \\
\hline cherry, plum, peach & Prunus spp. \\
\hline chinaberry, Texas umbrellatree & Melia azedarach \\
\hline Chinese chestnut & Castanea mollissima \\
\hline Chinese tallowtree & Sapium sebiferum \\
\hline crown of goldtree & Cassia excelsa \\
\hline golden-chaintree & Laburnum anagyroides \\
\hline golden-raintree & Koelreuteria paniculata \\
\hline $\begin{array}{l}\text { Japanese pagoda tree, } \\
\text { Chinese scholartree }\end{array}$ & Sophora japonica \\
\hline Kentucky coffeetree & Gymnocladus dioicus \\
\hline maple, box elder & Acer spp. \\
\hline osage orange & Maclura pomifera \\
\hline Peruvian peppertree & Schinus molle \\
\hline walnut & Juglans spp. \\
\hline
\end{tabular}

Table 6. Broadleaf evergreen trees or shrubs that should not be planted around livestock and horses

\begin{tabular}{|c|c|}
\hline Common name & Scientific name \\
\hline acacia & Acacia spp. \\
\hline andromeda, pieris & Pieris spp. \\
\hline boxwood & Buxus spp. \\
\hline croton & Codiaeum variegatum \\
\hline daphne & Daphne spp. \\
\hline $\begin{array}{l}\text { geranium-leaf aralia, } \\
\text { coffeetree }\end{array}$ & Polyscias guilfoylei \\
\hline holly & Ilex spp. \\
\hline Japanese aucuba & Aucuba japonica \\
\hline leucothoe & Leucothoe spp. \\
\hline mountain laurel & Kalmia latifolia \\
\hline oleander & Nerium oleander \\
\hline Peruvian peppertree & Schinus molle \\
\hline photinia & Photinia spp. \\
\hline pittosporum & Pittosporum spp. \\
\hline privet & Ligustrum spp. \\
\hline rhododendron, azalea & Rhododendron spp. \\
\hline spurge, euphorbia & Euphorbia spp. \\
\hline St. Johnswort & Hypericum spp. \\
\hline yew & Taxus spp. \\
\hline
\end{tabular}

Table 7. Vines that should not be planted around livestock and horses

\begin{tabular}{|l|l|}
\hline Common name & Scientific name \\
clematis & Clematis spp. \\
creeper & Menispermum canadense \\
goldcup, chalice vine & Parthenocissus spp. \\
ivy & Solandra spp. \\
lantana, shrub verbena & Hedera spp. \\
matrimony vine & Lantana spp. \\
Mexican flame vine & Lycium halimtolium \\
monstera & Senecio confusus \\
morningglory & Monstera spp. \\
philodemdron & Ipomoea spp. \\
star jasmine & $\begin{array}{l}\text { Philodendron } \text { spp. } \\
\text { Trachelospermum } \\
\text { trumpet plant }\end{array}$ \\
\hline
\end{tabular}




\section{Poisonous Rangeland Plants}

Livestock suspected of being poisoned by plants on rangeland can create a challenge in that the plants can be difficult to find in a large expanse of range. This section discusses the most important rangeland species of concern.

\section{Arrowgrass (Triglochin spp.)}

Arrowgrasses are native grasslike plants. The semicircular fleshy leaves arise from the base of the plant. Leaf clumps are 6 to 8 inches tall. Cattle and sheep are more frequently poisoned by arrowgrass than are horses. In California, arrowgrass is found in mudflats and alkaline places from the coastal salt flats to springy places above the timberline. The plants are most toxic when stressed or damaged due to frost, wilting, stunting, or physical damage (mowing, chopping, etc.). Plants lose their toxicity with drying.

\section{Signs of poisoning and treatment}

The toxic compounds in arrowgrass contain cyanide and are found in leaves, fruit, and seeds of mature fruit. The highest concentrations are present in newly developing leaves. Cyanide blocks cellular respiration, and poisoning progresses so rapidly that death usually occurs within minutes after onset. Affected animals may show signs of labored breathing, frothing at the mouth, incoordination, muscle tremors, and convulsions. Specific antidotes are available from your veterinarian, but they will be effective only if treatment is initiated rapidly after the onset of signs. Eradication of the plant is not practical. The plant is somewhat palatable to stock, and its occurrence in hayfields should be noted. It should be avoided during dry seasons and after frost.

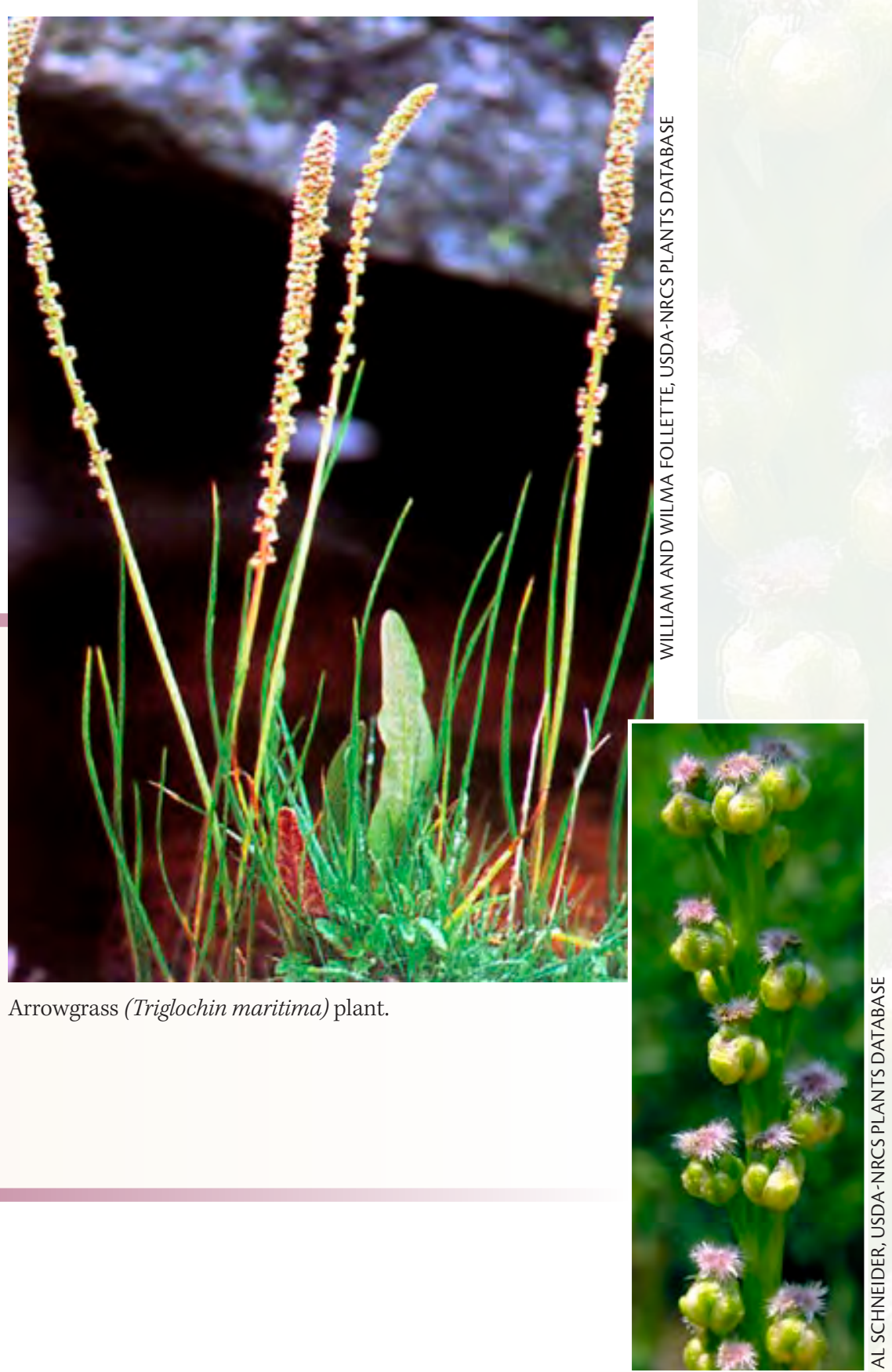

Arrowgrass (Triglochin maritima) inflorescence. 


\section{Chokecherry (Prunus virginiana)}

Western chokecherry (P. virginiana var. demissa and melanocarpa), often simply called chokecherry, is a native shrub or small tree 3 to 15 feet tall with flossy, finely toothed leaves. The flowers are white, showy, and fragrant, and they appear in May and June in California. The dark red to black fruit is bitter but edible and grows to $1 / 4$ inch in diameter. Chokecherry is found along streams and in damp places in woods and brushy areas. It is found in the coast ranges and the Sierra, generally below 8,200 feet, from San Diego County north. Sheep and goats can be affected, and extensive losses of cattle may occasionally occur. Losses of horses are rare. The younger leaves are more toxic than mature leaves, and by late summer the plant may become more palatable and provide good forage for cattle. Wilted leaves are toxic, and cuttings of the plant should be removed from areas where livestock graze.

\section{Signs of poisoning and treatment}

The toxic compounds in chokecherry are the same as those in arrowgrass, so the signs and treatment are identical. In order to prevent chokecherry poisoning, hungry or thirsty animals should not be trailed through areas where chokecherry is abundant. Eradication on a large scale is not practical, but near watering and loafing areas, chokecherry may be removed with a herbicide.

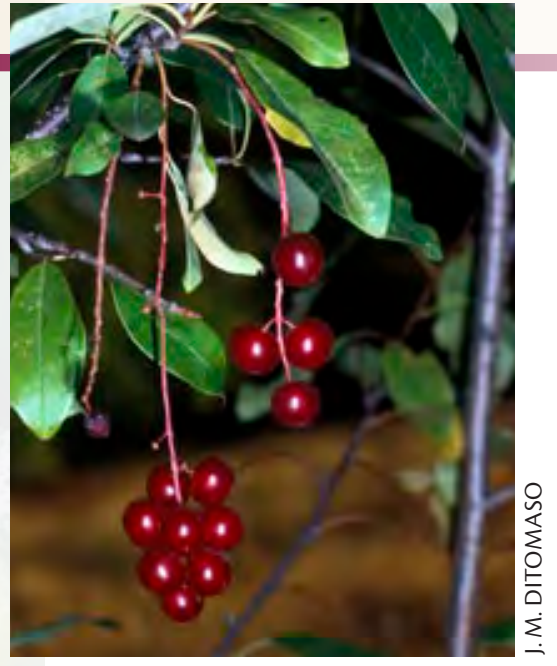

Chokecherry (Prunus virginiana) fruit

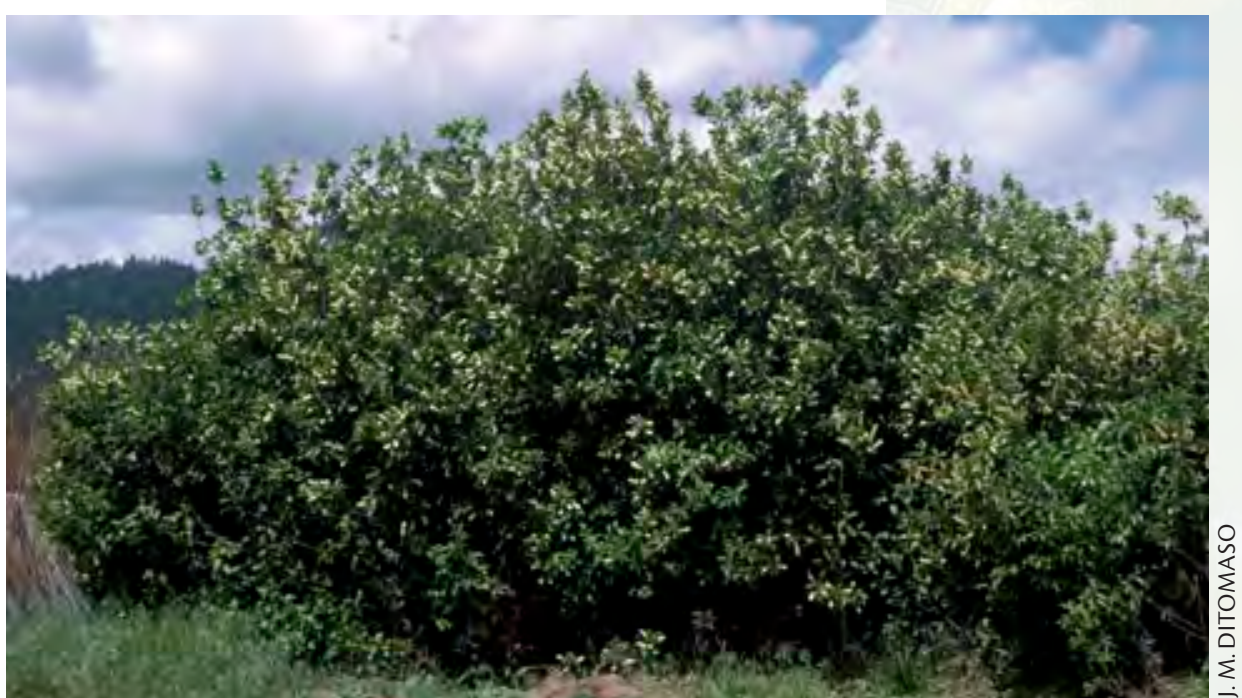

Chokecherry (Prunus virginiana) plant.

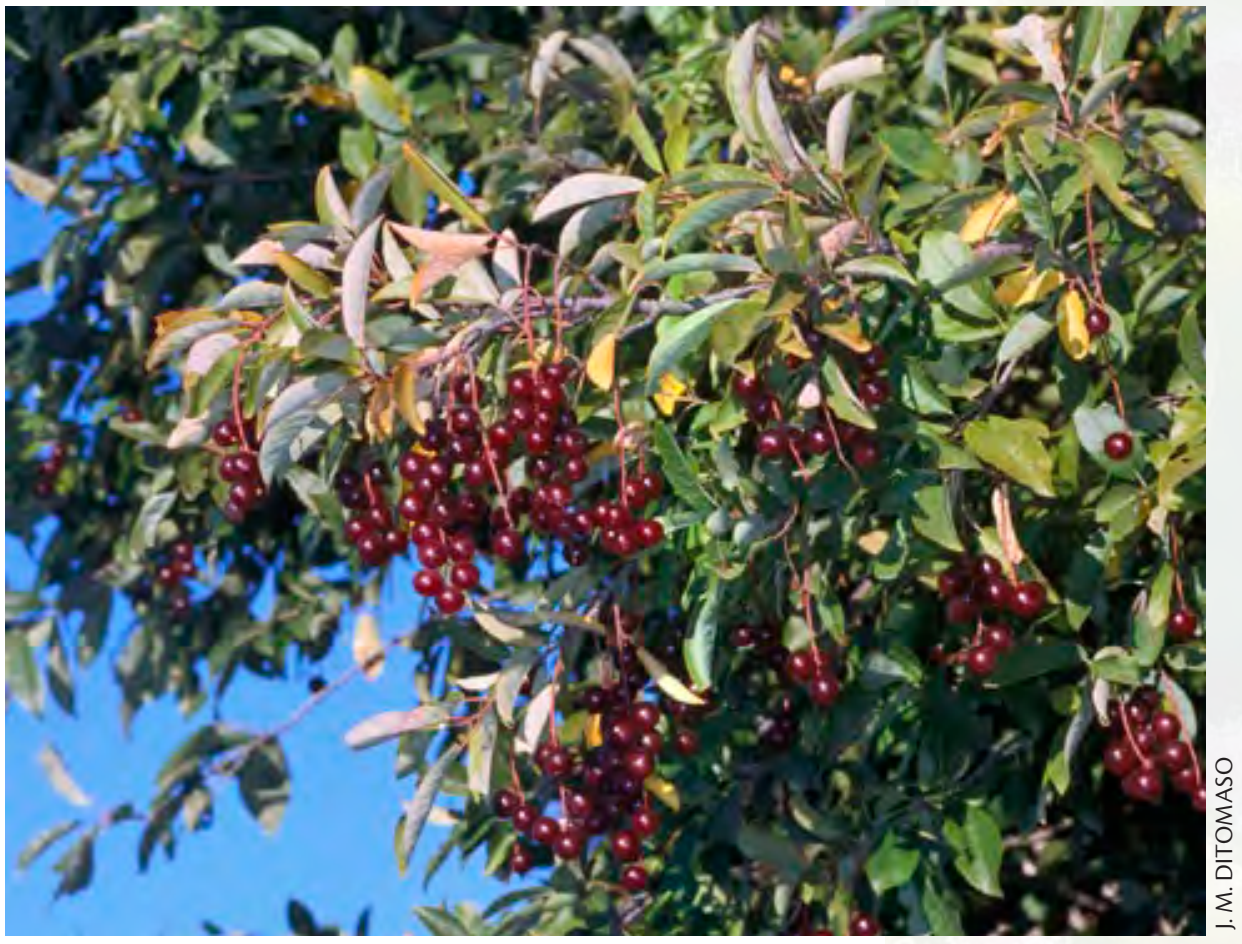

Chokecherry (Prunus virginiana) flowering stem. 


\section{Cocklebur (Xanthium spinosum and X. strumarium)}

Cockleburs are weedy native annual plants that grow to about 3 feet tall. Leaves of common cocklebur (X. strumarium) are roughly triangular or heart shaped and are covered with minute hairs on both sides. The brown or greenish brown fruits, or burs, are covered with stiff, hooked spines and contain two seeds. Cockleburs are found in moist waste places throughout the state, generally at lower elevations. Floodplains, old fields, overgrazed pastures, and stock watering places are common habitats. Spiny cocklebur (X. spinosum) is not as common as common cocklebur and can be distinguished by its smaller leaves and sharp, spiny stem.

\section{Signs of poisoning and treatment}

The toxic compound in cocklebur is concentrated in the germinating plants. The seed and the two-leaf-cotyledon stage of the plant is the most poisonous. Although the toxin remains potent when these portions of the plant are preserved in hay, the toxin is not present in the four-leaf stage or the mature plant. Cocklebur seeds can also contaminate grains used in concentrate rations fed to livestock. Cases of cocklebur poisoning have been reported in cattle, sheep, and pigs. Consumption of as little as 0.75 percent of body weight of germinating plants can cause death, with signs occurring a few hours after ingestion of cocklebur sprouts or seeds. Signs of cocklebur poisoning in pigs and cattle include depression, weakness, loss of appetite, reluctance to move, incoordination, excitability, muscle spasms, and an unusual gait with erect ears and head held high. Lying down, paddling of limbs, and convulsions followed by coma and death can occur within hours to days of consumption. There is no specific treatment for cocklebur poisoning. Cocklebur should be eliminated with mowing, cultivation, or herbicide use. While cocklebur is highly susceptible to herbicides, more than one treatment is required for complete elimination, because only one of the two seeds in a bur germinates in the first year.

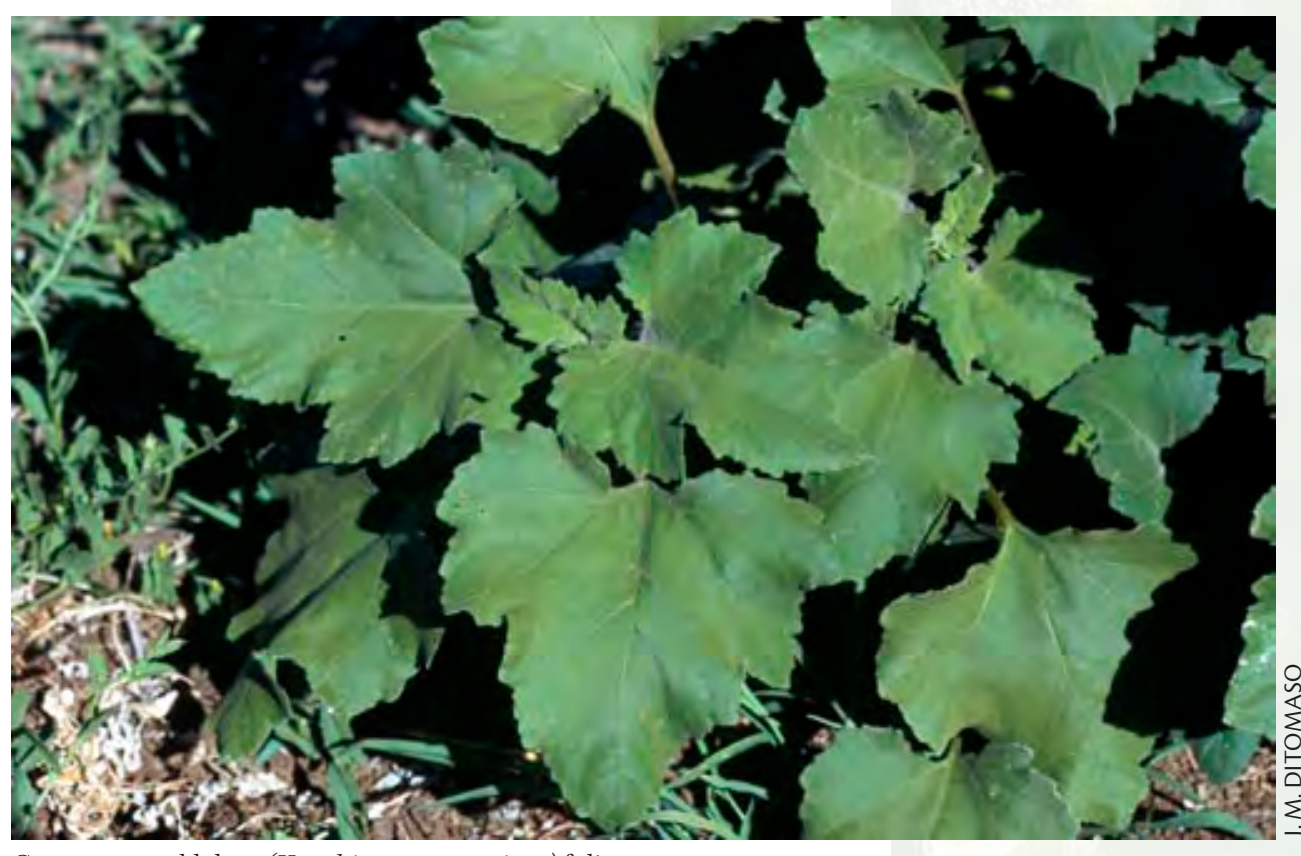

Common cocklebur (Xanthium strumarium) foliage.

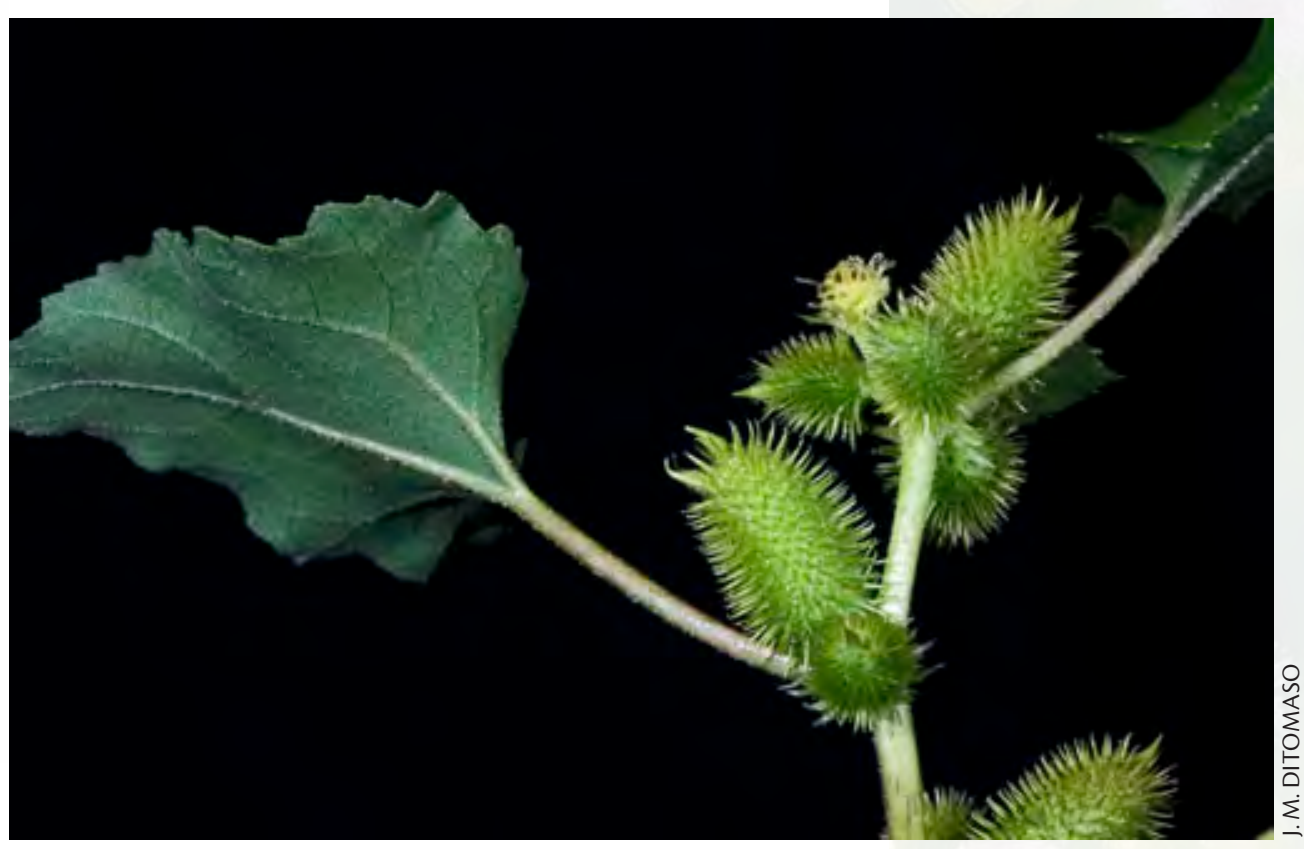

Common cocklebur (Xanthium strumarium) flowers on stem. 


\section{Curly Dock (Rumex crispus)}

Curly dock is a common weed in irrigated pastures. It is a perennial unbranched plant that can vary in height. The leaves are alternate and oblong to lanceolate with wavy margins; the flowers are terminal racemes or panicles and the inflorescence turns dark brown when dry. All parts of the plant are toxic.

\section{Signs of poisoning and treatment}

The toxic compound in curly dock is soluble oxalate; signs of poisoning (dullness and listlessness, incoordination, weakness, and coma) can occur within 5 hours of consumption. Death follows rapidly, generally within a day. There is no effective treatment. Ruminants are most commonly affected, but the toxin may occasionally affect horses.

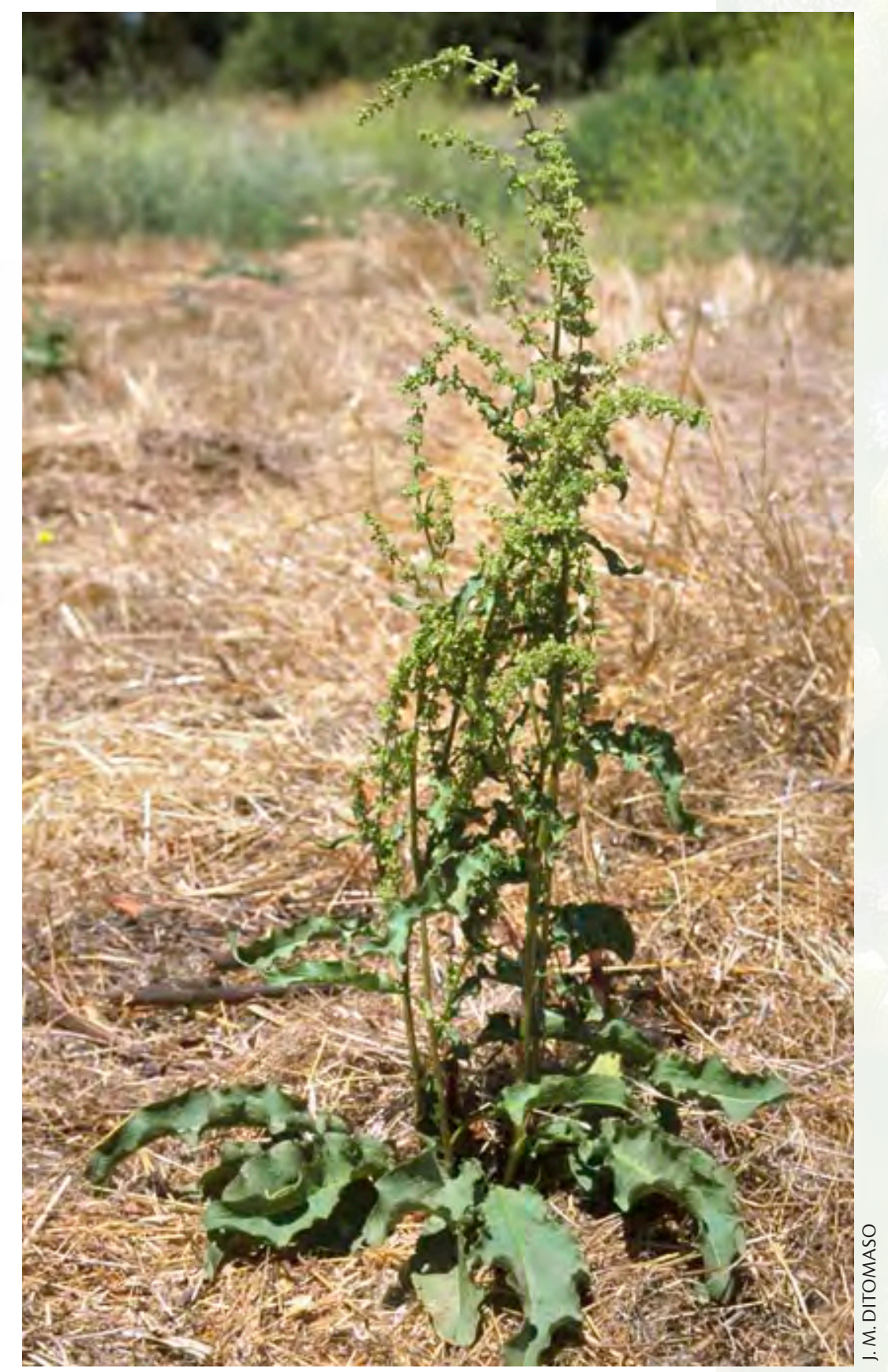

Curly dock (Rumex crispus) along river floodplain. 


\section{Deathcamas (Zigadenus spp.)}

Deathcamas, a member of the lily family, consists of about 6 different species. It is grasslike and has greenish or yellowish white flowers that arise from a burled bulb. Flowers occur in a cluster atop a central stalk. These perennial plants are 4 to 18 inches tall. Deathcamas is found in moist, grassy places below 8,200 feet in both the coastal ranges and the Sierra. Zigadenus paniculatus, commonly known as sandcorn or foothill deathcamas, is found in rocky soil in Nevada and Siskiyou Counties and is considered one of the most toxic of the species. The plants begin to grow early in the season and are green in the spring. Most losses result from earlyseason grazing, when more palatable forage is not available. Toxicity varies with stage of growth: the early stages of growth, especially seeds and fruit, are the most toxic. Sheep are most commonly affected; cattle and horses can be affected but usually find the plant unpalatable.

\section{Signs of poisoning and treatment}

In sheep, ingestion of 1 percent of body weight of the green plant is lethal, while consumption of 0.2 to 0.5 percent of body weight of the green plant can cause serious illness. Losses of livestock are uncommon but can be very severe when they occur. Range sheep can easily ingest the amount necessary to produce toxicity, especially when hungry. Signs include excessive salivation, depression, colic, trembling, incoordination, drooping ears, respiratory failure, convulsions, coma, and death. Keeping stock off spring ranges that contain deathcamas until ample forage is available is the best way to avoid poisonings. Supplemental feed can be offered to animals to prevent consumption of this relatively unpalatable plant. Herbicides can control large infestations of the plant if applied early in the spring.

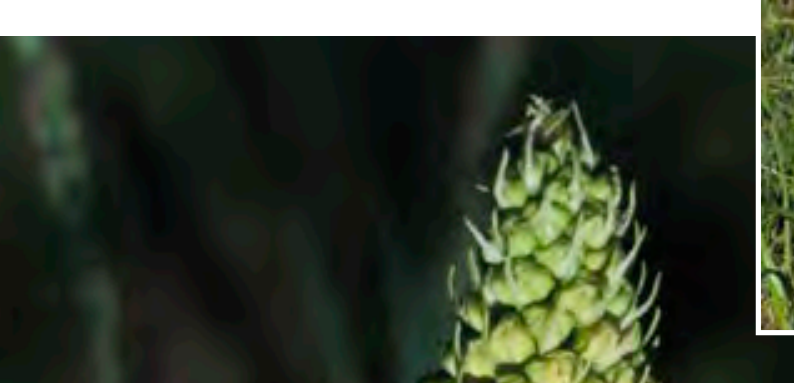
6. 69.

Meadow deathcamas (Zigadenus venenosus) plant.

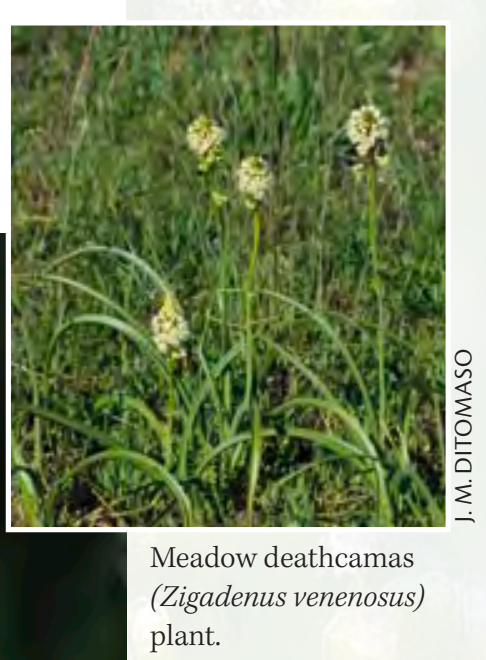

\footnotetext{
Meadow deathcamas (Zigadenus venenosus) flower head.
}

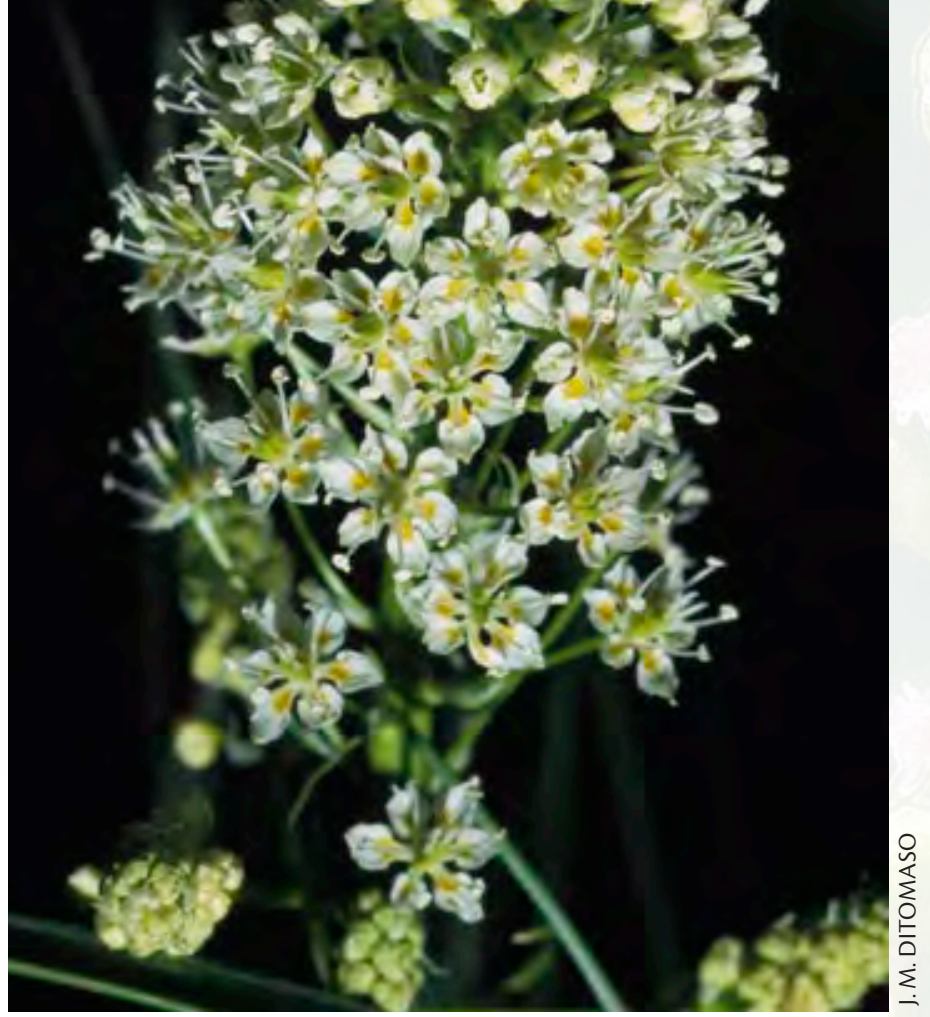




\section{Dogbane and Indianhemp (Apocynum spp.)}

These Apocynum species plants are erect, spreading perennial herbs with tough, fibrous bark. Stems branch toward the top and are 20 to 40 inches tall. The leaves are dark green above, paler and downy beneath, ovate, and from 2 to 3 inches long. The flowers are white and tinged with red, with five scales in the throat of the corolla. The seedpod is a long (up to 6 inches), narrow, cylindrical pod containing elongated cottony seeds. Dogbane plants are bitter and are consumed only when dried in hay. The plant contains toxic cardiac glycosides similar to those found in oleander. Dogbane can be found in moist areas throughout the state.

Signs of poisoning and treatment

For signs and treatment measures associated with exposure to cardiac glycosides, see the oleander section, above.

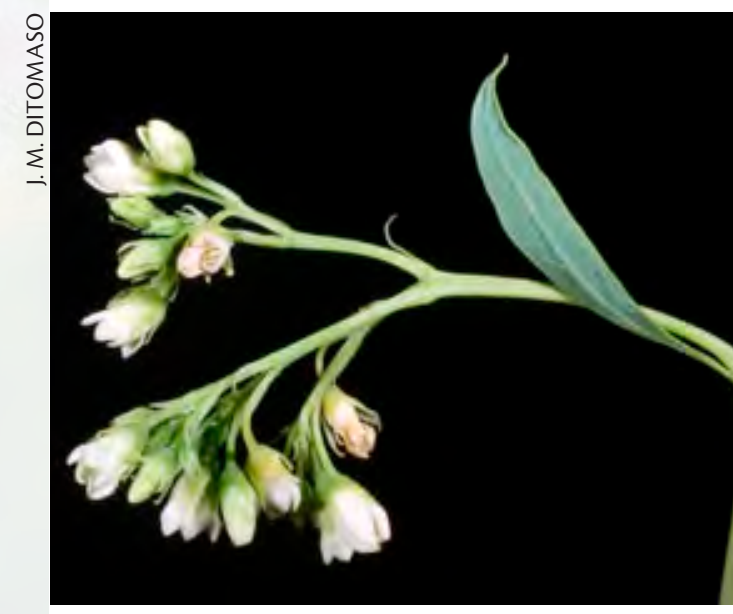

Indianhemp (Apocynum cannabinum) flowering stem.

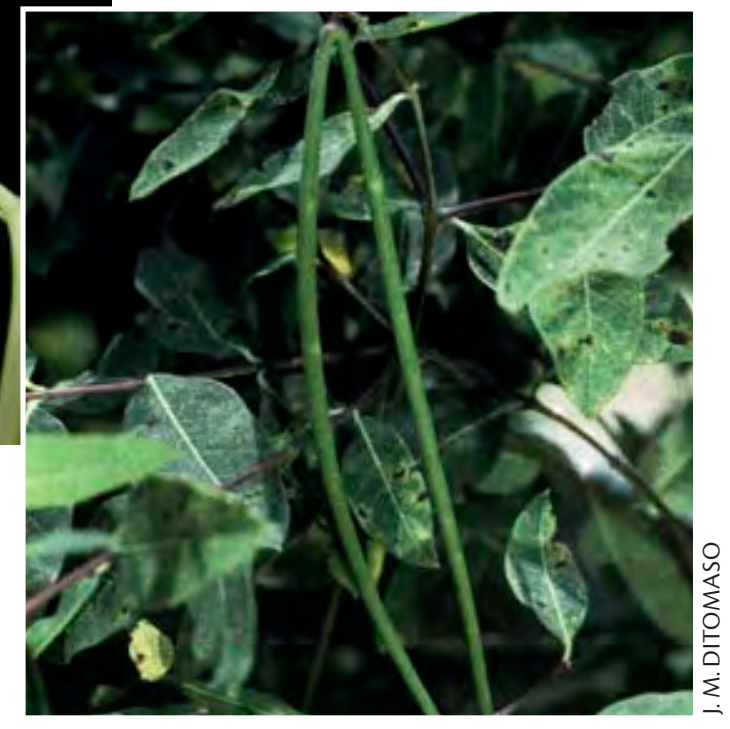

Indianhemp (Apocynum cannabinum) fruit.

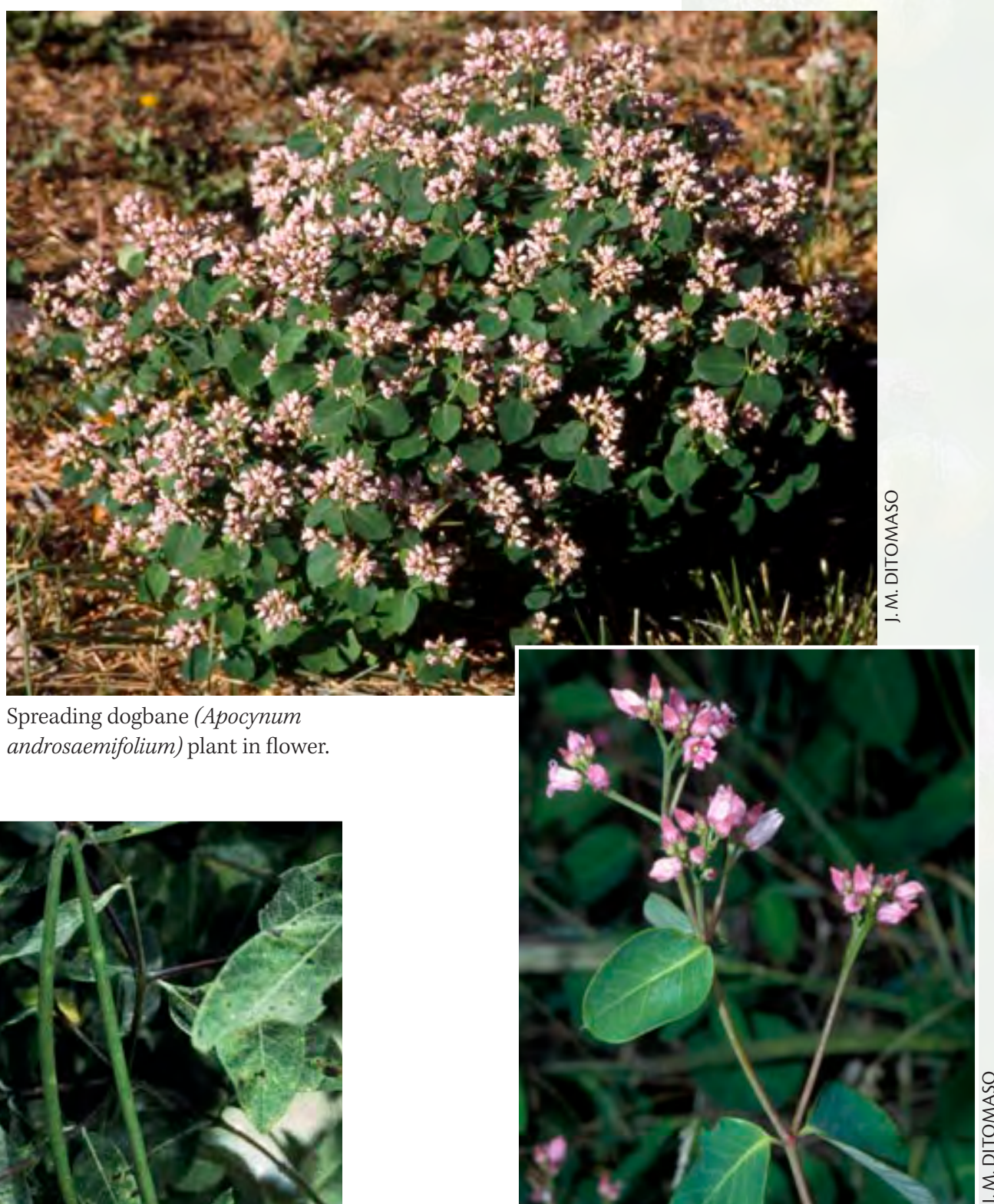

Spreading dogbane (Apocynum androsaemifolium) flowers. 


\section{Fiddleneck (Amsinckia spp.)}

The third-most-commonly-diagnosed cause of plant poisoning in California is caused by pyrrolizidine alkaloids (PAs). Two plant genera, Amsinckia and Senecio, are most commonly responsible for these cases.

Fiddleneck, also called rancher's fireweed and tarweed, is widespread in California. It is characterized by coarse, hairy stems and leaves and small yellow flowers that are found in a coiled cluster like a fiddle's neck. Each flower produces four small brown or black nutlets. Fiddleneck is found in a number of California counties, generally in sandy or open places under 6,000 feet elevation. It is also a common weed in alfalfa and grain, appearing in hay and in wheat screenings. Horses and cattle are most sensitive to fiddleneck, but pigs are also affected, while sheep and goats are less susceptible. Dried fiddleneck can be toxic, with the toxic ingredients, pyrrolizidine alkaloids, concentrated in the seeds.

\section{Signs of poisoning and treatment}

Pyrrolizidine alkaloid poisoning can result in chronic, irreversible liver disease in animals. Clinical signs may not appear for 2 to 8 months after the first ingestion. Affected animals may develop loss of appetite, dullness, constipation or diarrhea, weight loss, jaundice (yellow discoloration of the visible mucous membranes), and sunburn in unpigmented areas (photosensitization). In horses, neurological signs (head pressing, wandering aimlessly, chewing) are commonly observed along with an awkward gait, actively pushing against fences, and biting the ground, themselves, or other objects. Clinical signs and death are usually a result of liver failure.

No proven effective treatment is known, and the prognosis for poisoned animals is poor. As an annual broadleaf herb, fiddleneck is susceptible to herbicides. Its appearance, in any amount, in hay or grain fields is cause for concern. On rangeland where its appearance is spotty and control is not practical, grazing with sheep may be appropriate.

\section{$\frac{6}{4}$}

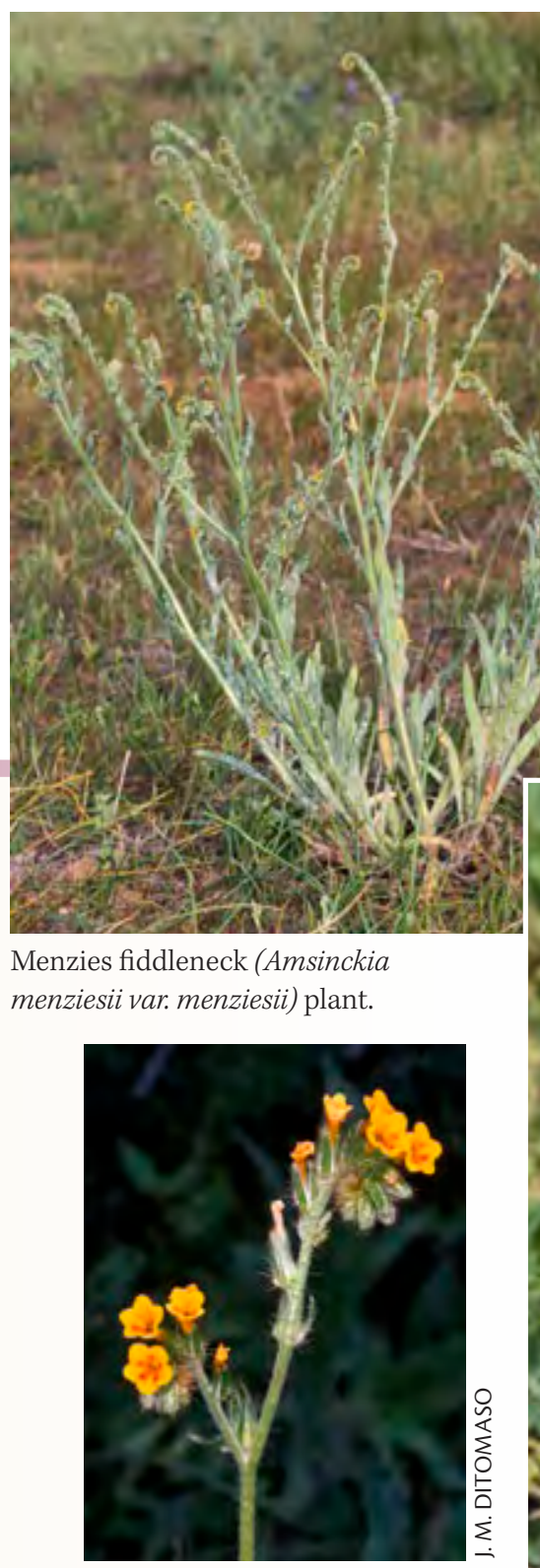

Coast fiddleneck (Amsinckia menziesii var. intermedia) inflorescence.

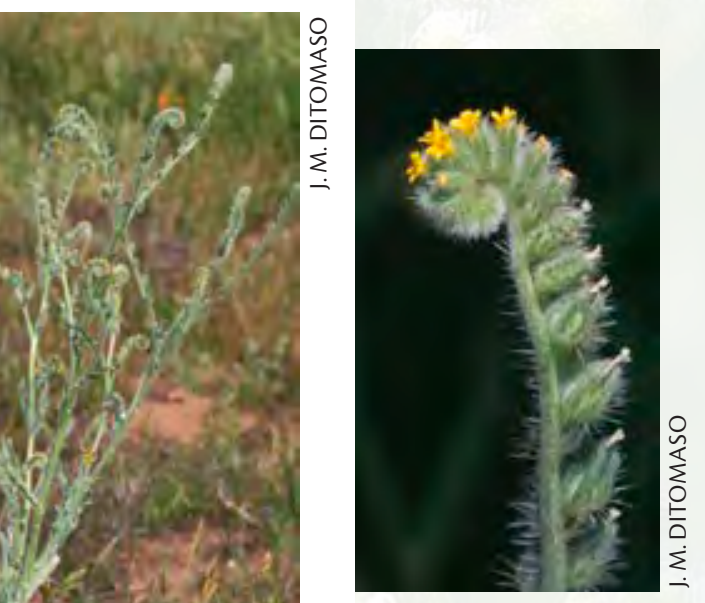

Menzies fiddleneck (Amsinckia menziesii var. menziesii) flowering stem.
Coast fiddleneck (Amsinckia menziesii var. intermedia) plant.

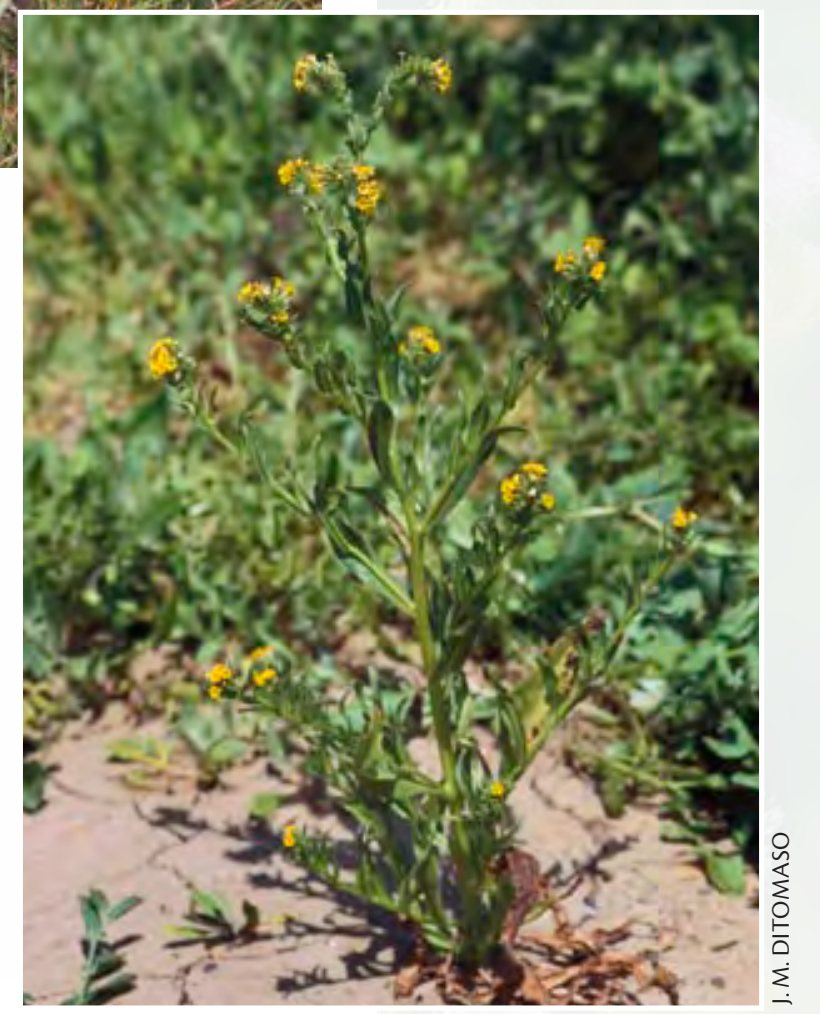




\section{Foxtail (Hordeum spp. and Setaria spp.)}

Plants such as foxtails that have sharp, barbed bristles or spines on their seed heads have been associated with injury and disease in animals. The plants are not toxic but mechanical injury from the bristles is a particularly serious problem in horses. Lesions are often seen in the mouth, and they cause pain and reluctance to eat. Deep ulcerations of the tongue, gums, and cheeks may lead to abscesses. Over the past few years, exposure of horses to alfalfa hay contaminated with foxtails has caused horses to develop blisters and lesions in the mouth and ulcerations on the tongue and lips. The alfalfa hay contained large amounts of two different species: green foxtail (Setaria viridis) and yellow foxtail ( $S$. pumila). Both species have sharp, barbed bristles, particularly yellow foxtail. These bristles can penetrate mucous membranes and cause serious erosions of the mouth. Problems usually occur when the hay is cut late and a substantial number of foxtail panicles are present. Although mainly a problem in horses, mechanical injury has also been reported in cattle. The bristles may be present in the wounds and must be removed. Alfalfa hay contaminated with foxtails should not be fed to livestock animals. It may be necessary to have a veterinarian evaluate all affected animals and initiate treatment, if necessary.

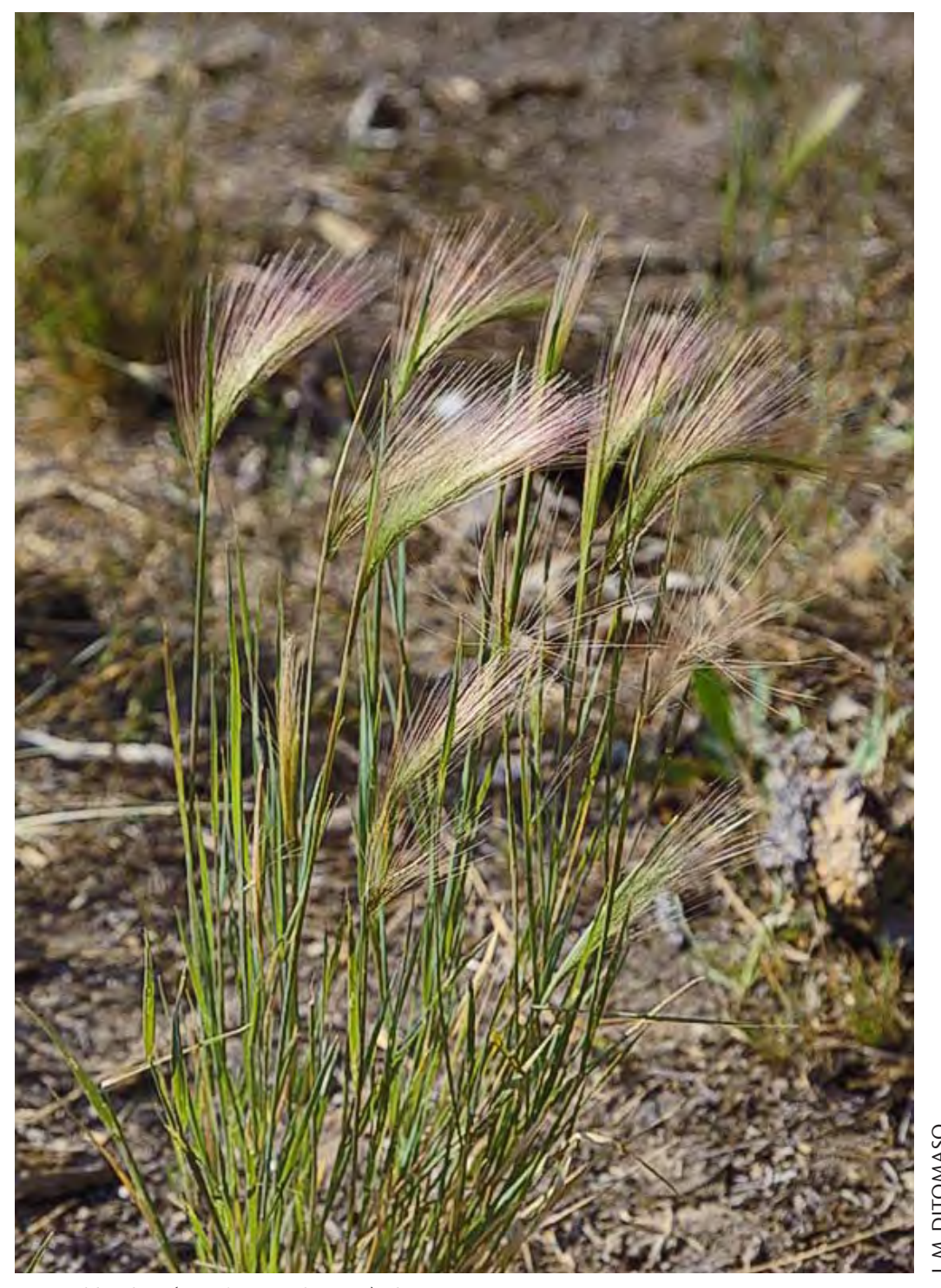

Foxtail barley (Hordeum jubatum) plant. 


\section{Greasewood (Sarcobatus vermiculatus)}

Greasewood is a shrub 2 to 6 feet tall with densely interlocking stiff, spiny, whitebarked branches. Leaves are $1 / 2$ to 2 inches long, bright green, strap-shaped, and somewhat fleshy. The greenish flowers are small and inconspicuous and give rise to cone-shaped fruiting spikes about $1 / 2$ inch long. In the fall, after the leaves have dropped, the spines are more conspicuous. In the California deserts, greasewood may retain its leaves as an evergreen.

In California, greasewood is found in alkaline places in desert valleys between 3,000 and 7,000 feet from Mexico north to Lassen and Modoc Counties. Sheep are most commonly poisoned, but cattle may be poisoned as well. The highest concentrations of the toxin (soluble oxalates) are in the leaves. If large quantities are ingested, the rumen's ability to detoxify oxalates is overwhelmed, and the oxalates may cause kidney damage. Early spring seems to be the most common season for poisonings. If consumed with other food, greasewood is valuable forage. Problems arise when greasewood is the major component of an animal's diet.

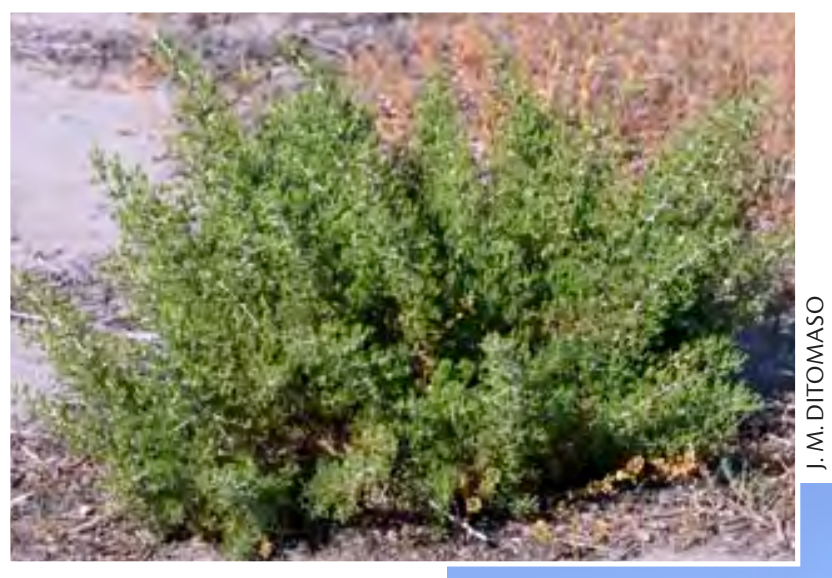

Greasewood (Sarcobatus vermiculatus) plant.

\section{Signs of poisoning and treatment}

Signs of poisoning (dullness and listlessness, incoordination, weakness, and coma) can occur within 5 hours of consumption. Death follows rapidly, generally within a day. There is no effective treatment. Since greasewood is a dominant plant in much rangeland east of the Sierra and provides useful forage, control is not practical. Provision of supplemental feed when greasewood is the only available forage will reduce losses.

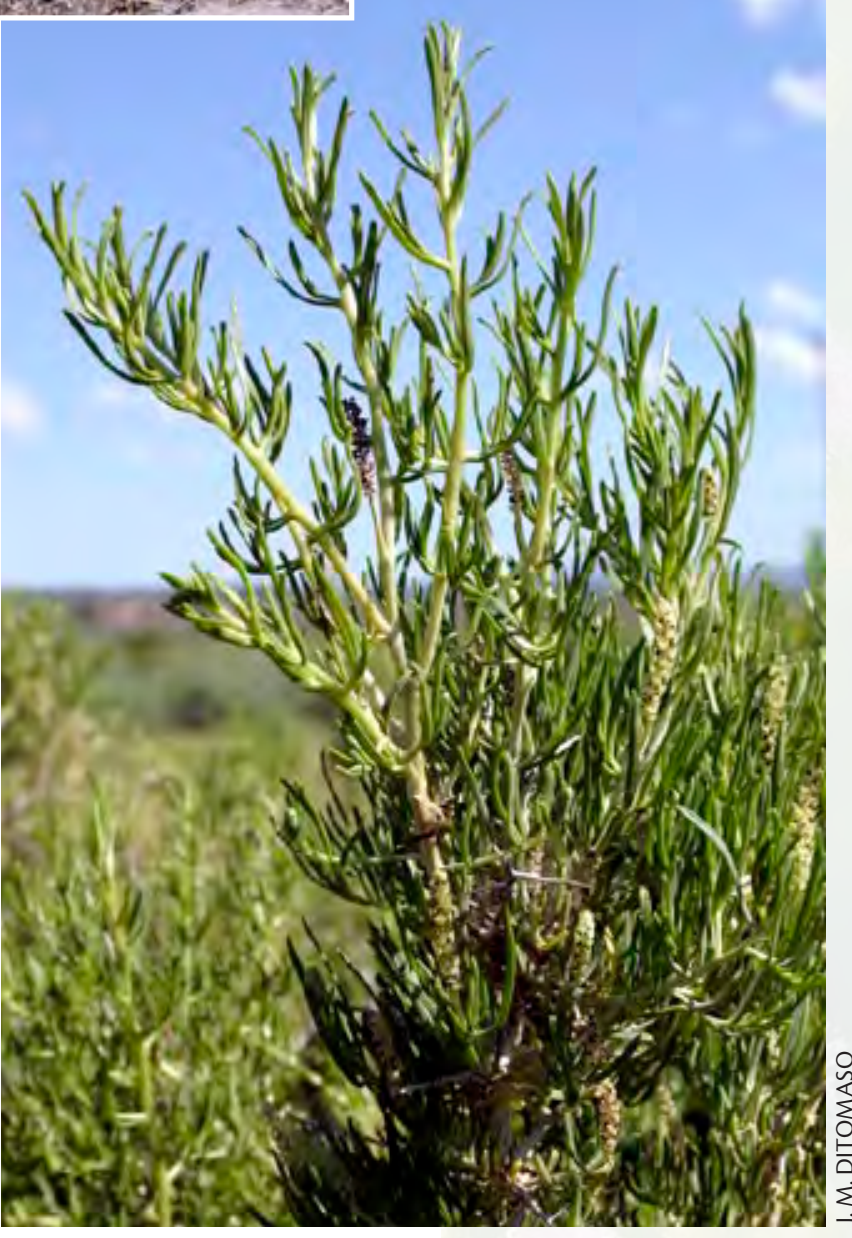

Greasewood (Sarcobatus vermiculatus) stem. 


\section{Groundsel and Ragwort (Senecio spp.)}

The groundsels and ragworts (Senecio spp.) are a large group of wildflowers and shrubs in the sunflower family. About forty species occur in California. They commonly have yellow flowers that resemble daisies, though the petals (rays) are longer and do not overlap. Three species of Senecio are of special concern:

- common groundsel (S. vulgaris), a common weed of gardens, alfalfa hayfields, and waste places

- tansy ragwort (S. jacobaea), found in creek bottomlands and pastures in the North coast counties

- western groundsel (S. integerrimus), found in wooded areas in the northern coastal ranges, the Sierra Nevada, and the White Mountains

Plants are usually not palatable and are poisonous both fresh and dried. Most cases of Senecio species poisoning are seen in horses and cattle, as sheep and goats are more resistant to the toxic effects.

\section{Signs of poisoning and treatment}

Clinical signs and recovery are the same as those described for fiddleneck. There is no effective treatment. Heavily infested ranges should be avoided by horses and cattle. Due to the prolonged delay in onset of clinical signs, prevention is the best control measure. Feed should be inspected carefully, and contaminated feed should be discarded. The pyrrolizidine alkaloid content of hay remains constant over many months. Silage contaminated with more than 5 percent Senecio species is considered unsafe for cattle or horse feeding. Senecio species can be controlled with an appropriate herbicide if applied when the plants are growing most rapidly; later treatments have no effect. The cinnabar moth (Tyria jacobaeae) has proved to be an effective biological control for tansy ragwort.
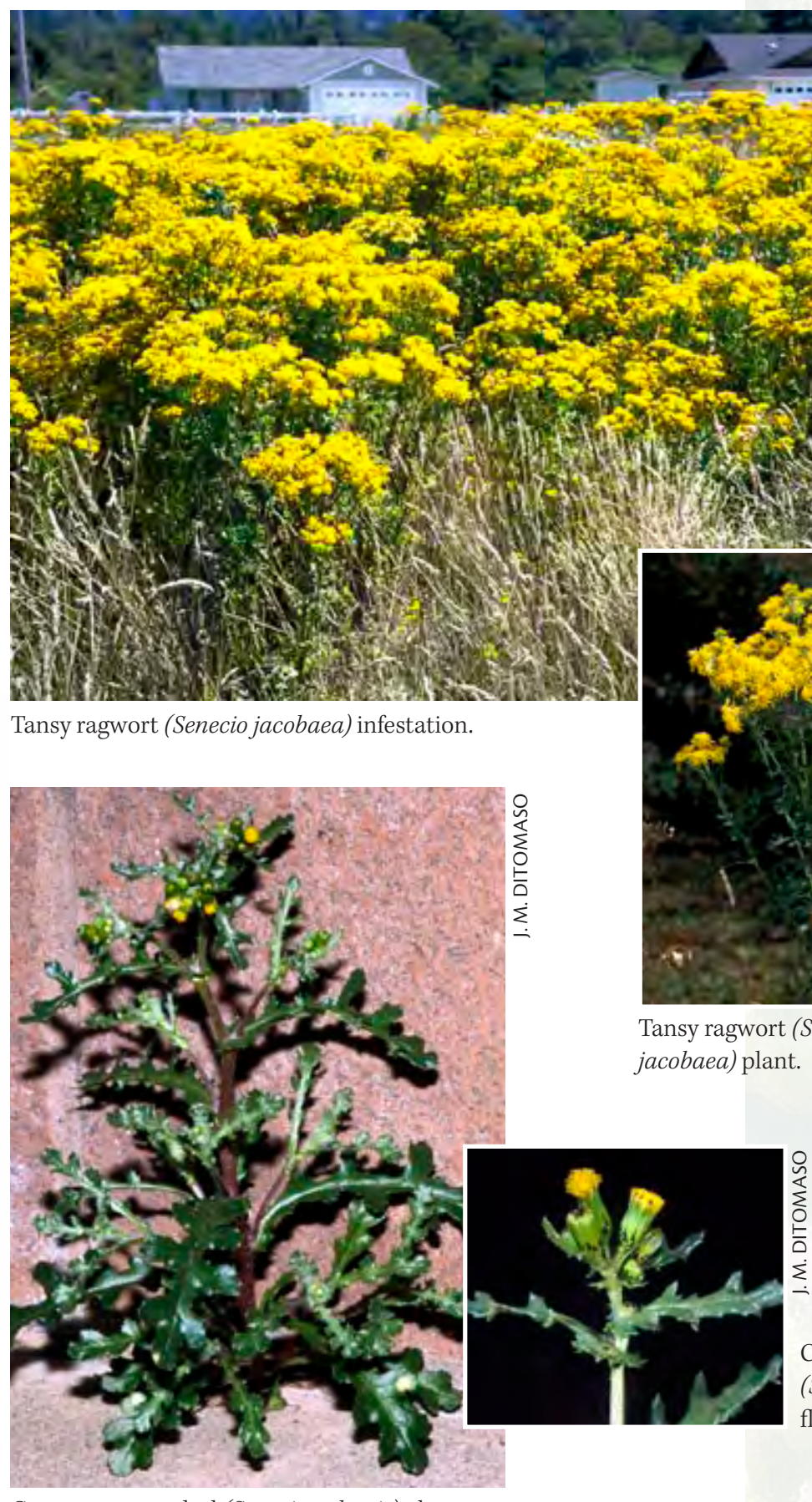

Common groundsel (Senecio vulgaris) flowering stem.

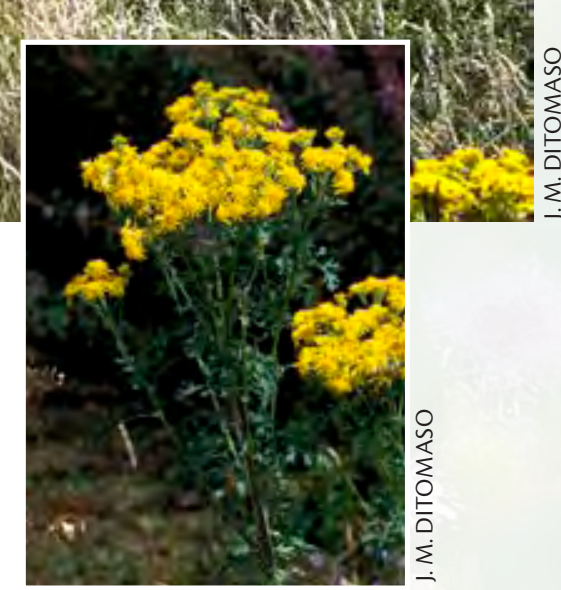

Tansy ragwort (Senecio

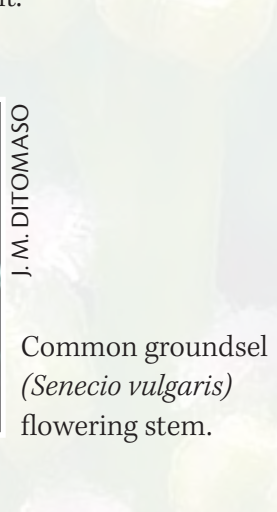

Common groundsel (Senecio vulgaris) plant. 


\section{Horsetail and Scouring Rush (Equisetum spp.)}

Horsetails and scouring rushes have dark green, hollow, jointed or segmented stems $1 / 4$ to $1 / 2$ inch thick with no true leaves. Stems may be singular or have whorls of branches in horsetails. Scouring rushes lack the whorl of branches. Jointed shoots emerge from the underground rhizome system and have conelike structures when mature. They can be found in riparian pastures and also in meadow hays.

\section{Signs of poisoning and treatment}

Horsetails and scouring rushes contain an enzyme (thiaminase) that destroys thiamine, a vitamin necessary for normal brain function. All parts of the plant, both fresh and dried, are toxic. Horses are most severely affected, and occasionally cattle and sheep. Newborn calves that are sucking cows consuming horsetails or scouring rushes are most susceptible. The calves will show signs of lying down and convulsions with the head arched straight back. Remove animals from the infested field or feed. Treatment includes the administration of thiamine.

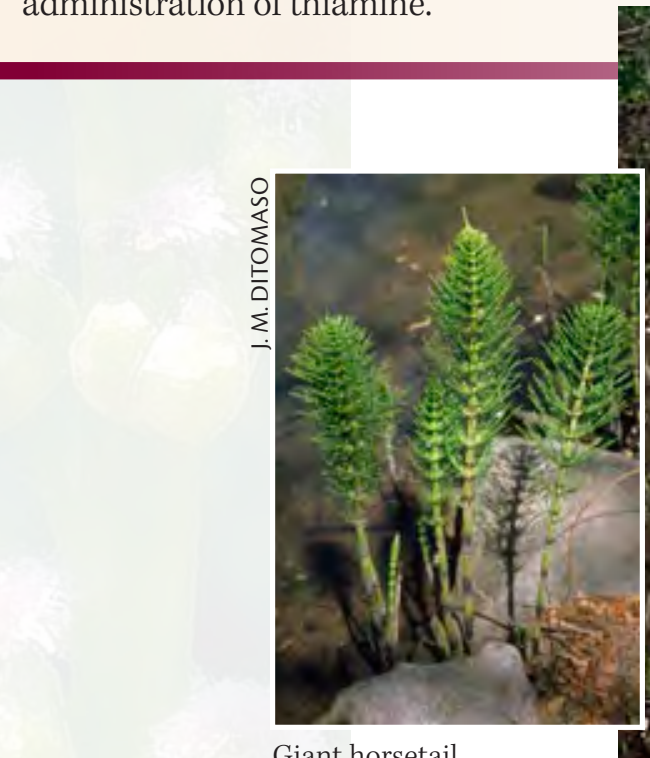

Giant horsetail

(Equisetum telmateia ssp braunii) stems.

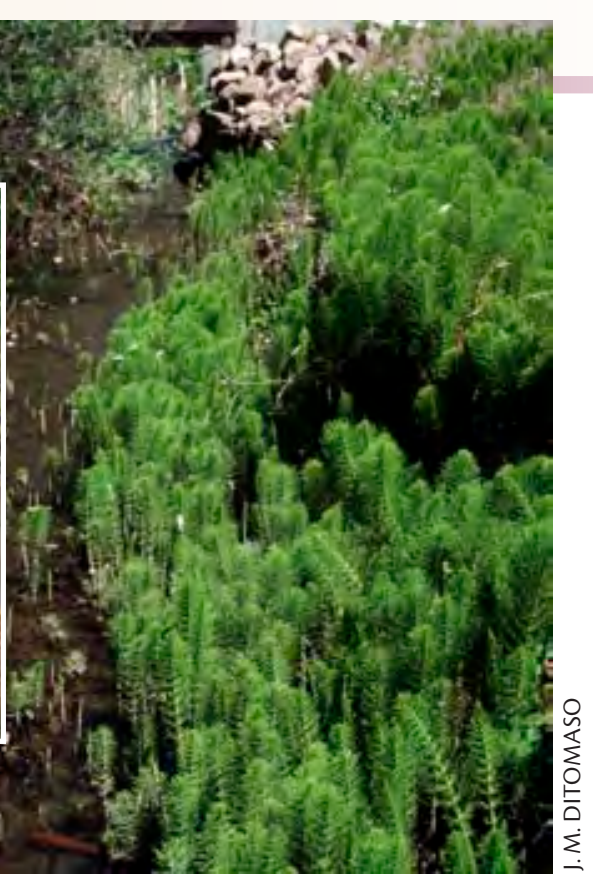

Giant horsetail (Equisetum telmateia ssp. braunii) along creek in native habitat.

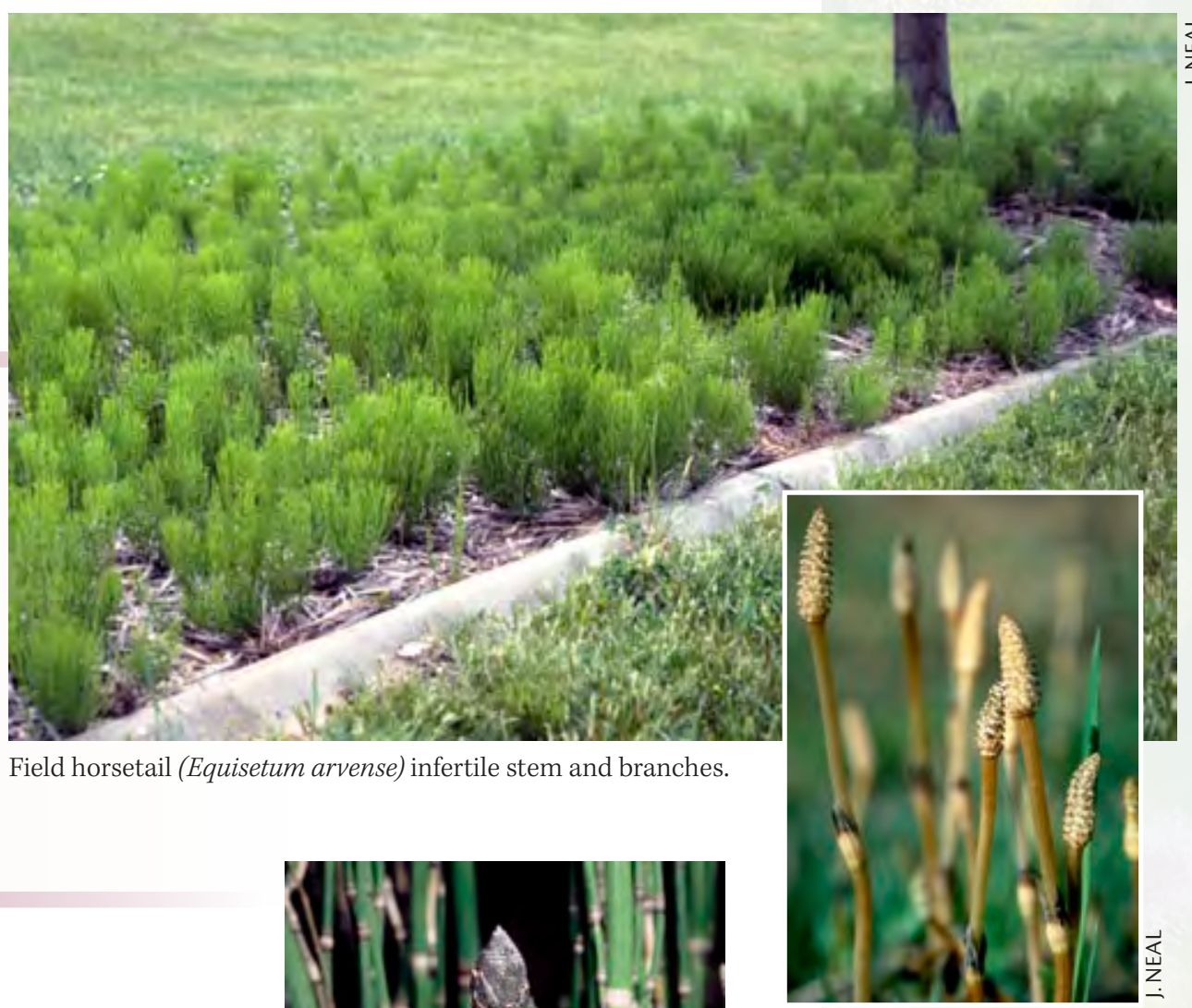

Field horsetail (Equisetum arvense) fertile stem.
Smooth scouringrush

(Equisetum laevigatum) stems.
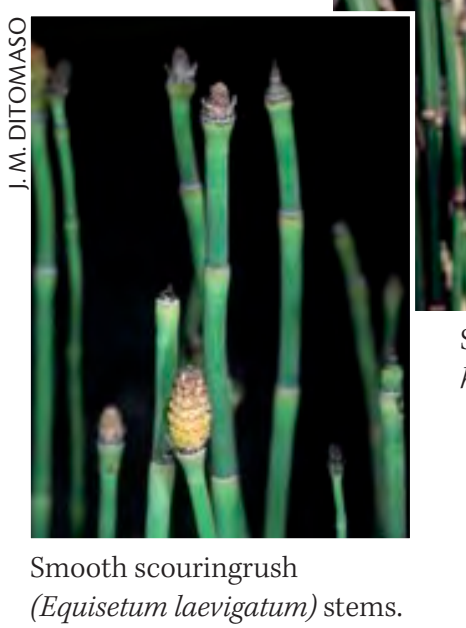

Scouringrush (Equisetum hyemale ssp. affine) stem. 


\section{Klamathweed or St. Johnswort (Hypericum perforatum)}

Klamathweed is a weedy perennial that grows up to $2^{1 / 2}$ feet tall. The dark, yelloworange, five-petalled flowers have black dots along the margins and are borne at the top of the stems. Leaves are arranged opposite each other along the stems and have small, pinhole-like dots that are translucent when held against the light. Klamathweed grows in pastures and abandoned fields under 4,500 feet in the Sierra from Tuolumne County north and in the Coast Range from Santa Cruz and Santa Clara Counties northward into Oregon. The plant is unpalatable and is eaten only when other forage is unavailable. Young cattle and sheep are most commonly affected, but any light-skinned animal may be adversely affected. Newly shorn sheep are especially susceptible.

\section{Signs of poisoning and treatment}

Klamathweed contains a toxin that results in photosensitization.

Photosensitization occurs when phototoxic or photoactive substances accumulate in the skin and interact with sunlight to produce a sunburn that can be severe. The extent of the skin damage is typically limited to the unpigmented skin on an animal that is exposed to sunlight, and it does not occur on darkly pigmented areas. Local swelling and skin damage can be mild to severe and painful and can lead to reduced feed intake. Affected animals will seek shade or turn away from the sun. Death is rare but affected animals become weak and unthrifty. Sensitized animals should be kept from sunlight. Animals not severely affected are likely to recover uneventfully. Allowing dark-colored animals to graze infested ranges may be helpful to control the weed. Proper application of a herbicide may control localized patches of klamathweed, while biological control by the klamathweed beetle is effective in controlling larger infestations.

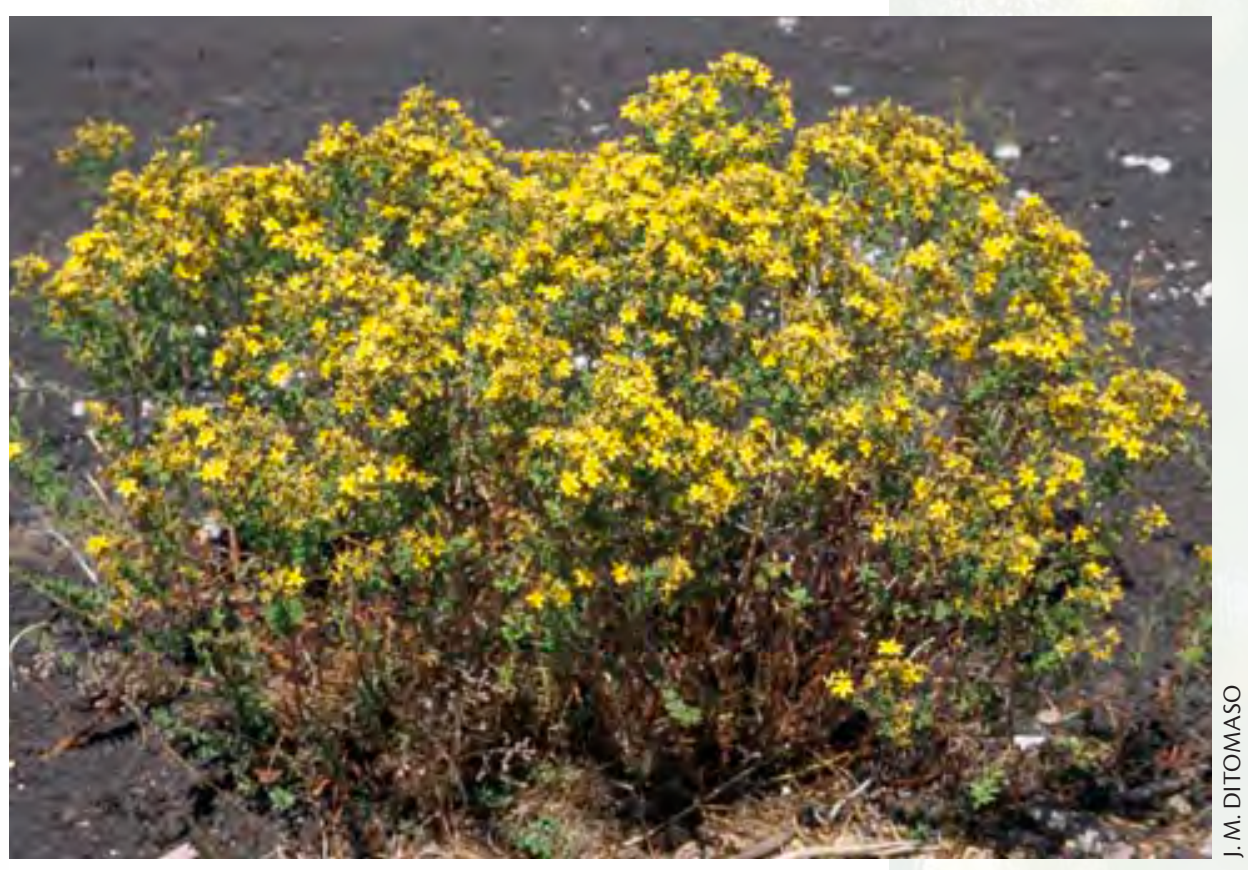

Klamathweed, or common St. Johnswort (Hypericum perforatum) plant.

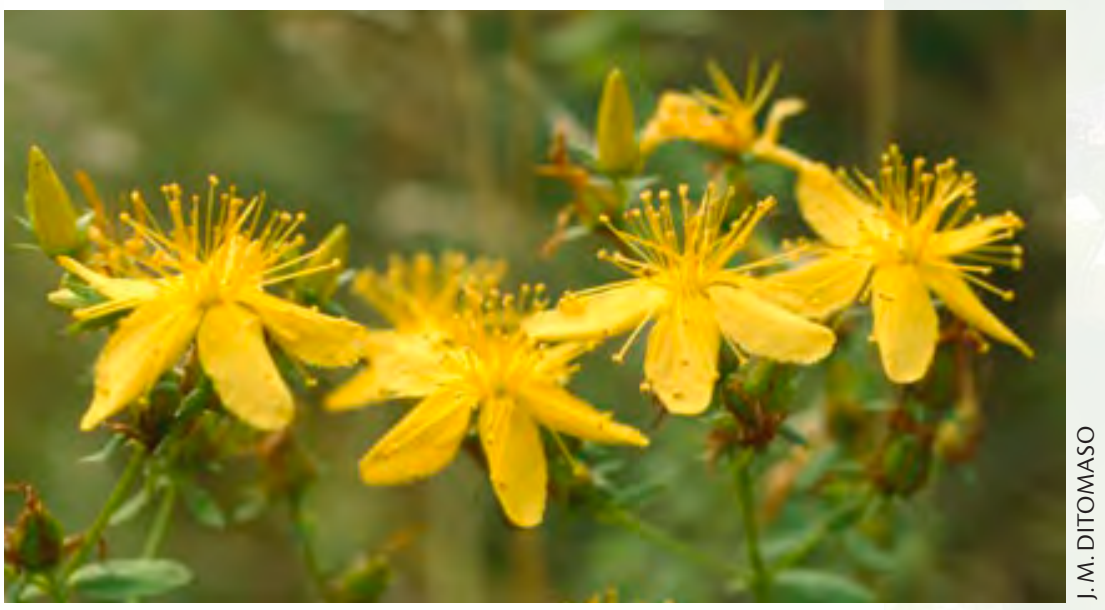

Klamathweed, or common St. Johnswort (Hypericum perforatum) flowers.

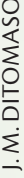




\section{Larkspur (Delphinium spp.)}

Larkspurs are characterized by palmately (spreading like the fingers of a hand) lobed or divided leaves and slender spikes of purple or blue (sometimes white to pink or lavender) trumpet-shaped flowers with a prominent spur at one end. Tall larkspurs grow 3 to 7 feet tall and are found in moist places like stream sides, mountain meadows, and shaded ravines. Low larkspurs are less than 3 feet tall and are found in grassy hillsides and desert areas. Larkspurs grow in a number of plant communities in mountain and foothill ranges throughout the state and can cause significant losses of cattle. Horses, goats and sheep are susceptible but are rarely affected. All species of larkspur in California are considered poisonous, but the toxin concentrations depend on the species and the stage of growth. Most poisonings occur during the "toxic window," the time when a specific larkspur plant is palatable and contains sufficient toxins to cause poisoning. Tall larkspurs are most toxic from the flowering period until the seedpods have matured. Low larkspurs are highly toxic and palatable early in the spring. Dried plants remain toxic.

\section{Signs of poisoning and treatment}

The toxins in larkspurs have a curare-like action that result in loss of motor function (especially in the diaphragm and esophagus), muscle weakness, and paralysis. Cattle are most susceptible, while sheep can tolerate about 4 to 5 times the amount that is fatal to cattle. Cattle are often found dead 3 to 4 hours after exposure. If clinical signs are observed, they include staggering and sudden falling, bloat, and respiratory distress. Do not stress poisoned animals. Because cattle will eat larkspur even when other forage is present, extensive stands of larkspur are cause for concern. Treatment of affected animals is useful only if a rapid diagnosis is made. Fencing affected areas, hand-grubbing localized patches, and spraying more widespread stands with herbicides can be appropriate measures, depending on local range conditions. Exposure of cattle to larkspurs during the "toxic window" must be avoided to effectively prevent poisoning. Sheep can be considered for biological control.

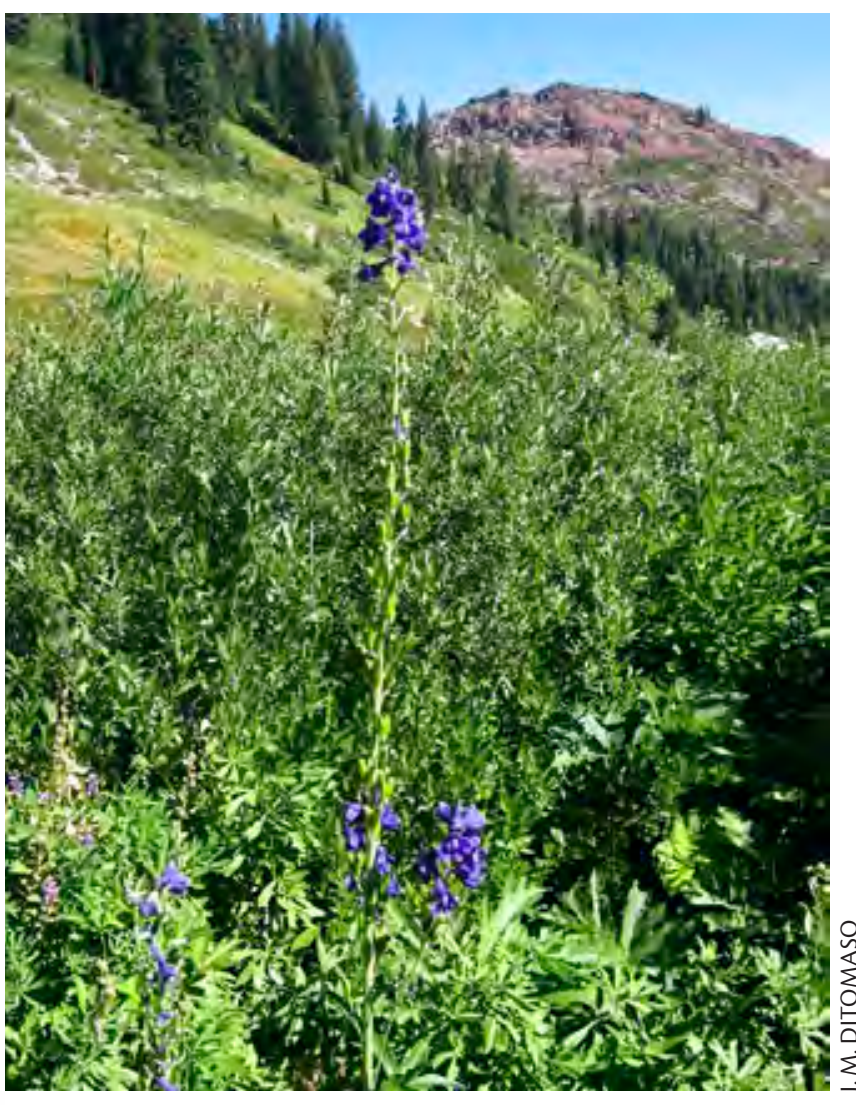

Tall larkspur (Delphinium glaucum) plant.

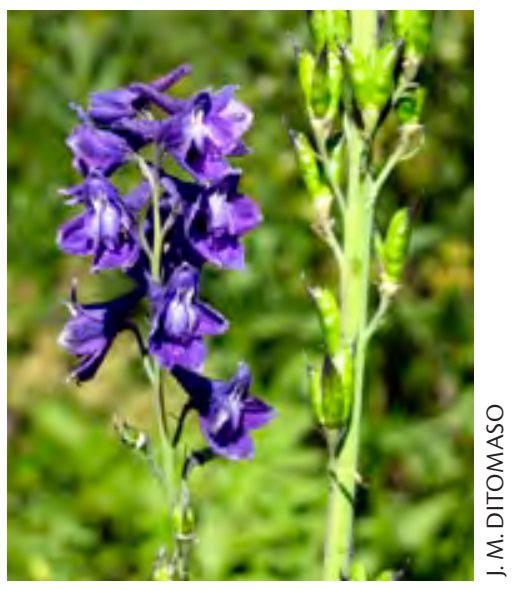

Tall larkspur (Delphinium glaucum) flowering and fruiting stem. 


\section{Locoweed and Milkvetch (Astragalus spp. and Oxytropis ssp.)}

More than 90 species of locoweeds are found in California. They are generally low or small bushy plants with white, purple, yellow, or orange pealike flowers. Leaflets are arranged opposite each other along the stem, with a single leaf extending from the tip of the stem. The seedpods are often inflated, giving rise to the name rattleweed. Locoweed is found in a number of plant communities and on a variety of soils but usually on dry and open sites. All parts of the plant are toxic at all stages of growth and when dry.

\section{Signs of poisoning and treatment}

Locoweeds (loco is Spanish for "crazy") can cause a number of diseases, but it is important to note that some locoweeds are nontoxic and can be used as forage. Locoweed poisoning, or locoism, can lead to abnormal behavior, infertility, abortion, heart failure, weight loss, and poor performance. Locoism has been reported in horses, cattle, sheep, goats, and elk. In horses, clinical signs of locoism include depression, circling, incoordination, and a staggering gait. Affected horses are difficult to handle and unpredictable and thus unsafe to ride. Cattle consuming locoweed at high altitude can develop congestive right-sided heart failure, also known as "high mountain disease." Clinical signs of poisoning are usually seen after consumption of large amounts of locoweed for 2 to 9 weeks; however, poisoning can occur almost immediately after ingestion. Livestock like to eat locoweed when it is in the flower and in the early seedpod stages, when the plant is most palatable and also contains the highest concentration of toxins. Signs of poisoning may last for several weeks, and the occasional animal that recovers is generally unthrifty and will eat locoweed to the exclusion of other forage if returned to a locoweed-infested pasture. Young animals seem more affected. Fetuses are especially susceptible to the effects of locoweed at 30 to 60 days gestation. Chronic poisoning can lead to "cracker heels", in which cattle and sheep click their hooves together while walking, knuckle over at the fetlocks, show posterior paralysis, are unable to stand, and have difficulty breathing ("roaring disease"). There is no specific treatment for the treatment of locoism and cracker heels, and animals usually do not recover.

Locoweeds also accumulate potentially toxic selenium concentrations. Ingestion of plants with high selenium concentrations can cause chronic selenosis in cattle and horses.

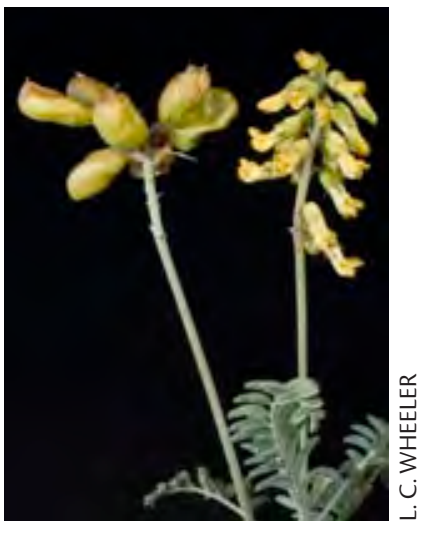

Locoweed (Astragalus

trichopodus and Astragalus oxyphysus) flowers and fruit.
Locoweed (Astragalus oxyphysus) plant. 


\section{Lupine (Lupinus spp.)}

Like the locoweeds, the lupines (table 8) are a large and varied group in the pea family. Leaves are palmate. Flowers, which may be white, yellow, pink, or more commonly blue and purple, are pealike and are borne on a showy spike. They develop into a pealike seedpod characteristic of legumes. Lupines may vary from 6 inches to 6 feet tall. The name "lupine" comes from lupus, the Latin word for "wolf," and these plants were once thought to rob the soil of nutrients since they are usually found on poorer sites. Like other legumes, however, lupines fix nitrogen and generally improve the soil they are growing on. They are commonly found in foothill and mountain areas on sandy or dry sites. Sheep, goats, and cattle are most commonly poisoned, but the plants may be toxic to all livestock. The toxic substances in lupine occur throughout the plant and are concentrated in the seeds; the plants are especially dangerous after seed set. Animals may be poisoned by lupine in hay. Not all lupines are highly toxic, and some may provide valuable supplemental forage. Problems occur when lupines constitute a major part of the diet. To determine whether any of these lupines are found in your area, see the Calflora Web site, http://www.calflora.org/.

\section{Signs of poisoning and treatment}

Signs of acute lupine poisoning include muscular trembling, incoordination, and excitement. Affected animals may wander aimlessly, push against objects, and appear dizzy. They finally collapse, breathing heavily, convulse, become comatose, and die. Crooked legs or other congenital abnormalities may be seen in calves from cows that ingested lupine between day 40 and 70 of pregnancy. As with most poisonous plants, losses most frequently occur when other forage is scarce. Poisoning by lupine can be reduced by avoiding lupine areas when trailing animals (especially sheep) and by avoiding the plants after the seeds set. Adjustment in the breeding schedule may be necessary on ranges where lupine causes congenital abnormalities. No effective treatment of poisoned animals is known.

Yellow bush lupine (Lupinus arboreus) plant.

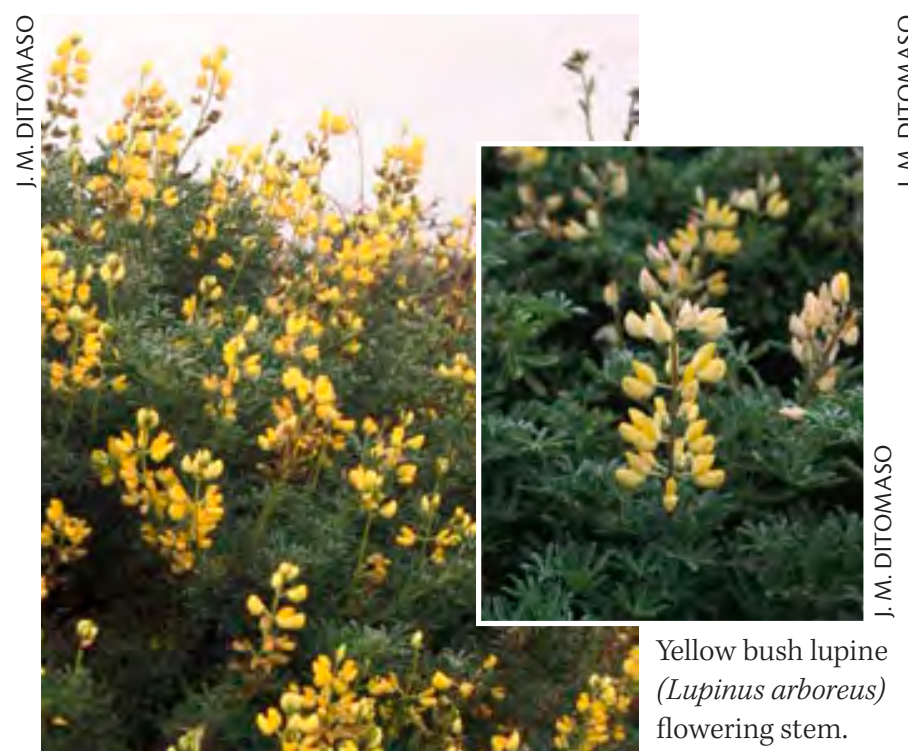

Table 8. Lupines (Lupinus spp.) of California that can be toxic

\begin{tabular}{|l|l|}
\hline Common name & Scientific name \\
\hline Anderson's & L. andersonii \\
broad-leaved & L. latifolius \\
dwarf & L. lepidus \\
grassland or western & L. formosus \\
longleaf bush & L. longifolius \\
low or rusty & L. pusillus \\
meadow & L. polyphyllus \\
mountain eddy & L. lapidicola \\
seashore & L. littoralis \\
sicklekeel & L. albicaulis \\
silvery or tailcup & L. argenteus \\
spur & L. arbustus \\
woodland or plumas & L. onustus \\
woolly-leaved or velvet & L. leucophyllus \\
\hline
\end{tabular}




\section{Milkweed (Asclepias spp.)}

At least 14 species of milkweeds are known to occur in California, but Only 3 species are important as poisonous plants to livestock. Woollypod milkweed (Asclepias eriocarpa) and showy milkweed (A. speciosa) both have broad, mostly hairy leaves attached directly to the main stem. In showy milkweed, leaves are attached on opposite sides of the stem; in woolly-pod milkweed, they are in a whorled or spiral arrangement. Mexican whorled milkweed (A.fascicularis) has long, narrow, essentially hairless leaves. All three species have milky sap, but the sap cannot be used to identify milkweeds because many other types of plants have it as well. These three species grow from 1 to 4 feet tall and have umbrella-shaped flower clusters, a boat-shaped seedpod, and hairy seeds. Milkweeds are found in dry places below 7,000 feet. They can be found in hayfields, and their toxicity is retained in hay. Most livestock species can be affected, but the greatest losses have occurred in sheep. Plants are unpalatable, and most losses occur when hungry animals are concentrated in infested watering areas, holding pens, or overgrazed pastures.

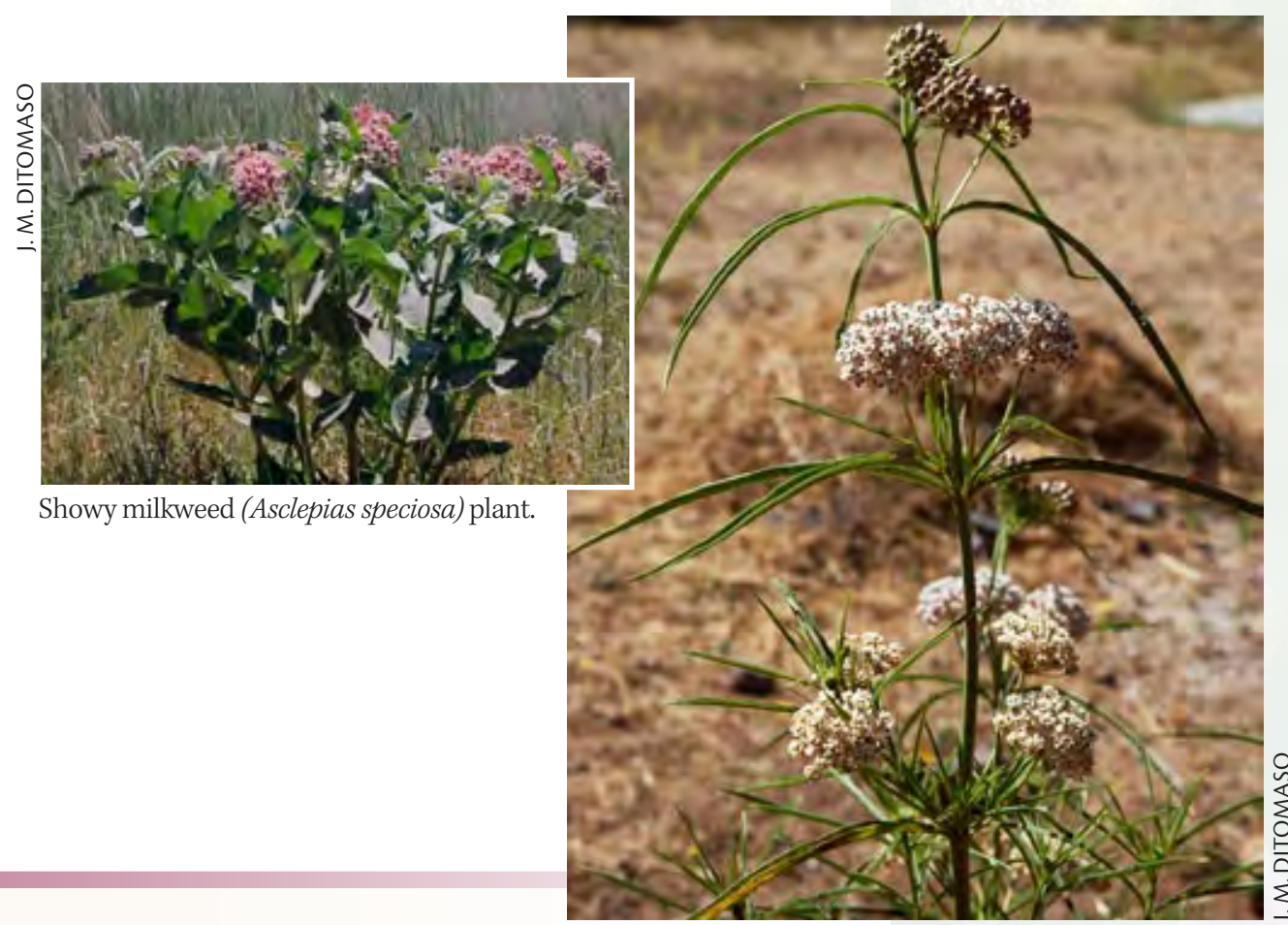

milkweed produces some signs similar to what is seen with broad-leaved milkweeds, namely depression and weakness.

Mexican whorled milkweed (Asclepias fascicularis) stem.
Milkweed toxins are similar to oleander toxins. In general, broad-leaved milkweeds are less toxic than narrow-leaved ones, but toxin concentrations vary with species and growing conditions. Signs of poisoning include colic or abdominal discomfort, incoordination, weakness, convulsions, and death due to respiratory failure. Cardiac signs include depression, weakness, irregular respiration, cardiac arrhythmias, and lying down. The broad-leaved showy and woollypod milkweeds primarily cause gastrointestinal distress. Foul odors from the mouth, bloat, and excessive salivation are noted. The animal becomes depressed and dull, has a lowered body temperature, and stands with a lowered head and humped back. Death may come quietly without spasms or convulsions. Signs usually appear 2 to 14 hours after the plant is eaten. Narrow-leaved
In addition, animals poisoned with narrow-leaved milkweed may fall down and show spasms in which the legs are rigidly extended. Signs of narrow milkweed poisoning usually appear 14 hours after the plant is eaten, but animals may also be found dead. There is no specific treatment for milkweed poisoning. Supportive therapy is recommended for animals that have not consumed a lethal dose, and animals may recover in several days. Preventive measures include avoiding contaminated hays and proper range management. Supplemental feeding, especially early in spring and late in fall, may be necessary. Milkweeds are difficult to control since they spread by widely scattered windblown seed and also by rootstocks. 


\section{Nightshade (Solanum spp.)}

At least 20 species of nightshades occur in California. The cultivated potato is Solanum tuberosum, and the cultivated tomato is closely related to the nightshades. The general identifying characteristic of the three most important poisonous species is the tomatolike, star-shaped flower with five lobes or petals and bright yellow central parts. The flowers are borne in small groups (penduncles) of one to eight flowers. The fruit is a small tomatolike berry that when ripe may be green (cutleaf nightshade, S. triflorum), dull black (black nightshade, S. nigrum), or yellow

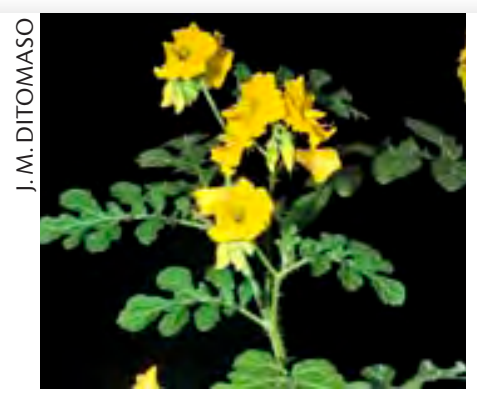

Buffalobur (Solanum rostratum) flowering stem. to brownish (silverleaf nightshade, S. elaeagnifolium). Cutleaf and black nightshades have white flowers, while those of silverleaf nightshade are blue or violet.

\section{Signs of poisoning and treatment}

The toxicity of a given nightshade species can vary widely due to environmental conditions, plant part ingested, and degree of plant maturity. Unripe berries are more toxic than ripe berries. Berries are more toxic than leaves, which are more toxic than stems or roots. The overall plant toxin content is often higher in the autumn than in the spring. The hazard of various nightshade species is quite erratic, and poisoning is rarely fatal. Animals must consume large amounts of nightshades to become intoxicated. Signs include loss of appetite, salivation, abdominal pain, vomiting, constipation, or diarrhea (with or without blood). Nervous system signs include drowsiness, progressive weakness or paralysis, lying down, and coma; they are followed by death or recovery within 1 to 2 days. Control of the plants is best accomplished by hand-grubbing, preferably before the seeds set in summer.

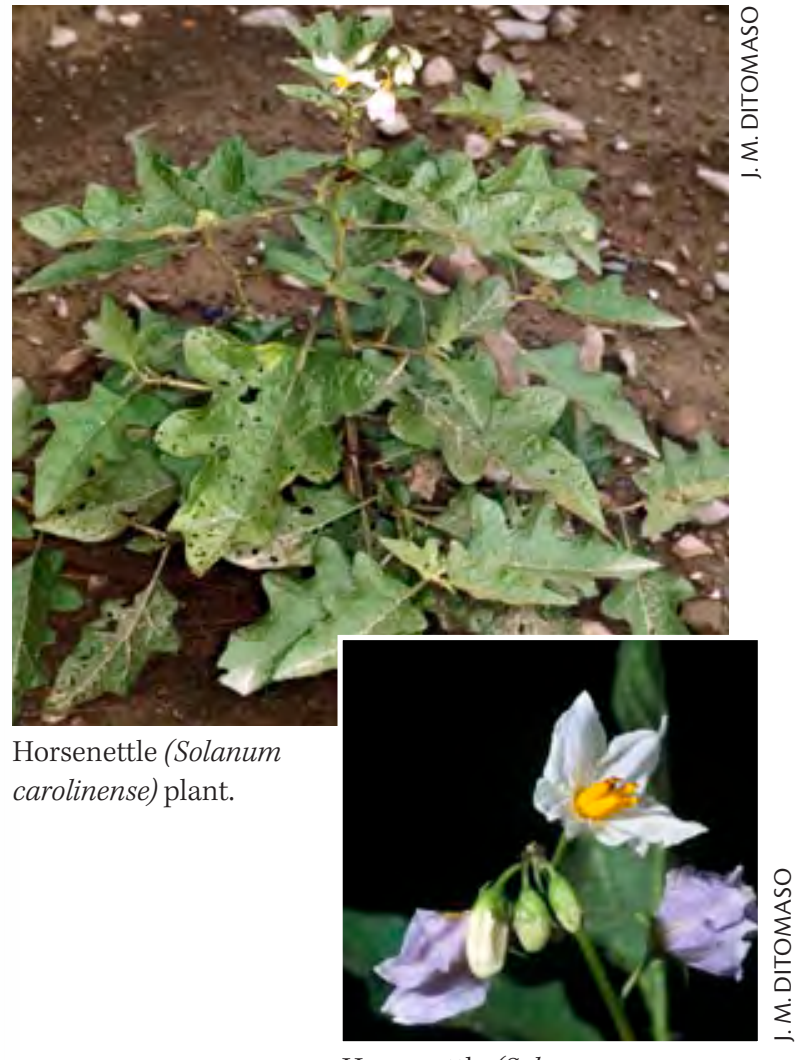

Horsenettle (Solanum carolinense) leaves.

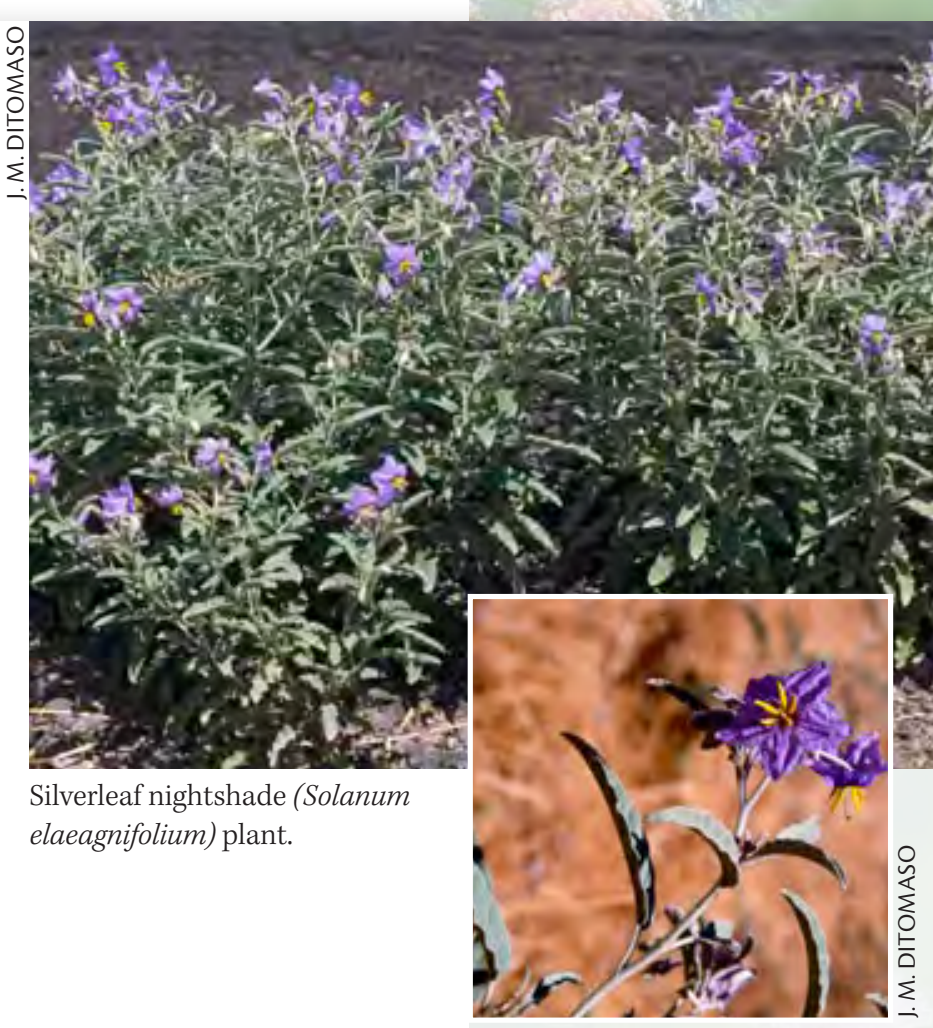

Silverleaf nightshade (Solanum elaeagnifolium) flowering stem.

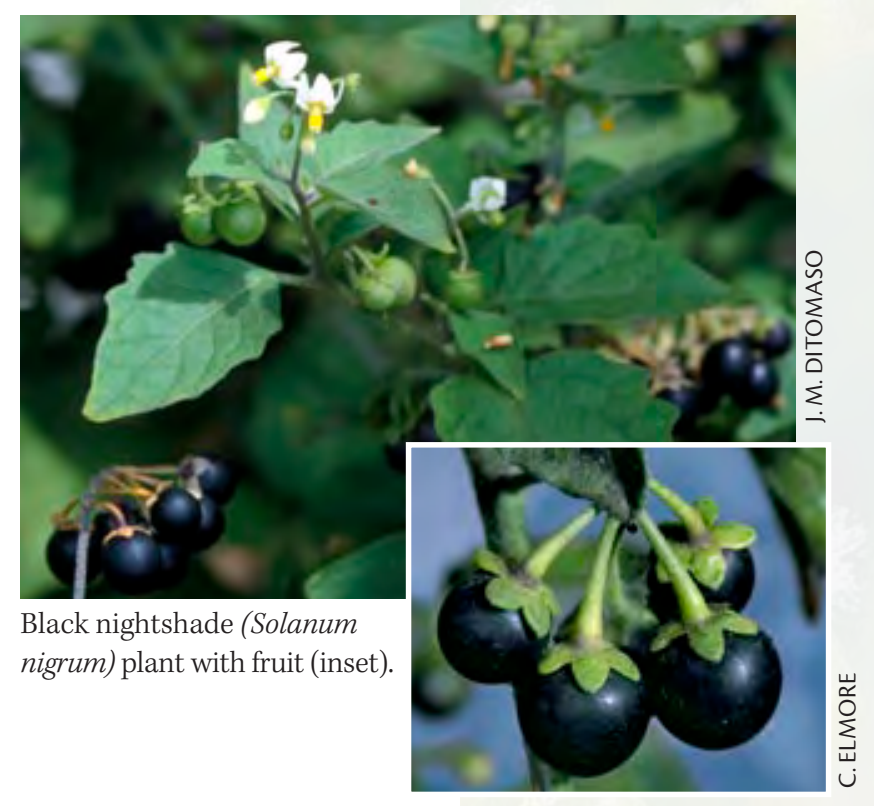




\section{Oaks (Quercus spp.)}

California is home to many oak tree species that are present in the valley and in coastal and mountain ranges. They produce acorns at levels that can vary from year to year. The highest level of acorn production may occur under drought conditions. All parts of the oak vegetation contain tannins and phenols of various concentrations. Poisoning is usually associated with the consumption of large amounts of buds, leaves, and acorns for 2 to 3 days or longer. Most cases of oak poisoning have been reported in cattle, but horses have also experienced digestive disturbances after eating them. Sheep, and to a lesser degree goats, can also be affected. Goats have tannin-binding proteins in their saliva and a slower digestive system that allow them to tolerate twice as much tannin as can cattle. Deer have even more effective tannin-binding salivary proteins that allow for a high intake of tannins without any adverse effects. Young oak buds emerging in the spring contain the highest concentrations of tannins. This was demonstrated by the latespring snowstorm of 1985 that limited feed options, when cattle consumed newly emerging oak leaves and buds, killing an estimated 2,700 calves from 60 ranches in three northern California counties.

\section{Signs of poisoning and treatment}

Tannins can irritate the digestive system and produce bloody scours (diarrhea). Continued consumption can also lead to kidney damage. In small calves, oak exposure can be lethal, while larger cows may never recover from the poisoning, remaining thin due to impaired kidney function. Sick animals can be supported by providing fluid therapy for hydration and antibiotics to prevent secondary bacterial infections. If cows consume a diet made up largely of acorns, buds, or leaves during the third to seventh month of gestation, congenitally malformed "acorn calves" may be born. These calves have very short legs, abnormal hooves, and short noses or long narrow heads. Oak poisoning may be prevented by providing adequate feed, especially during droughts; if a late-spring snowstorm occurs, range cattle should be fed hay immediately.

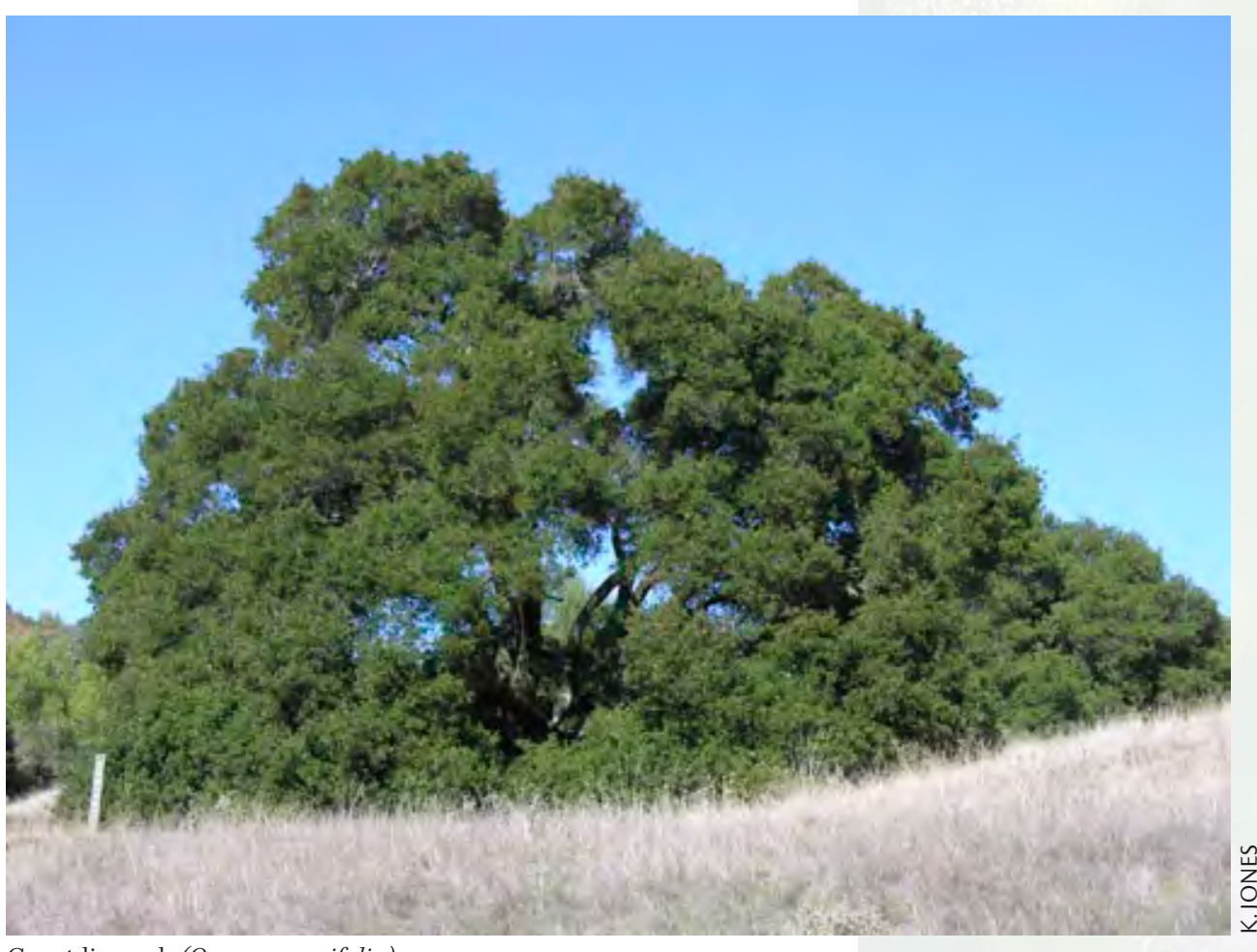

Coast live oak (Quercus agrifolia).

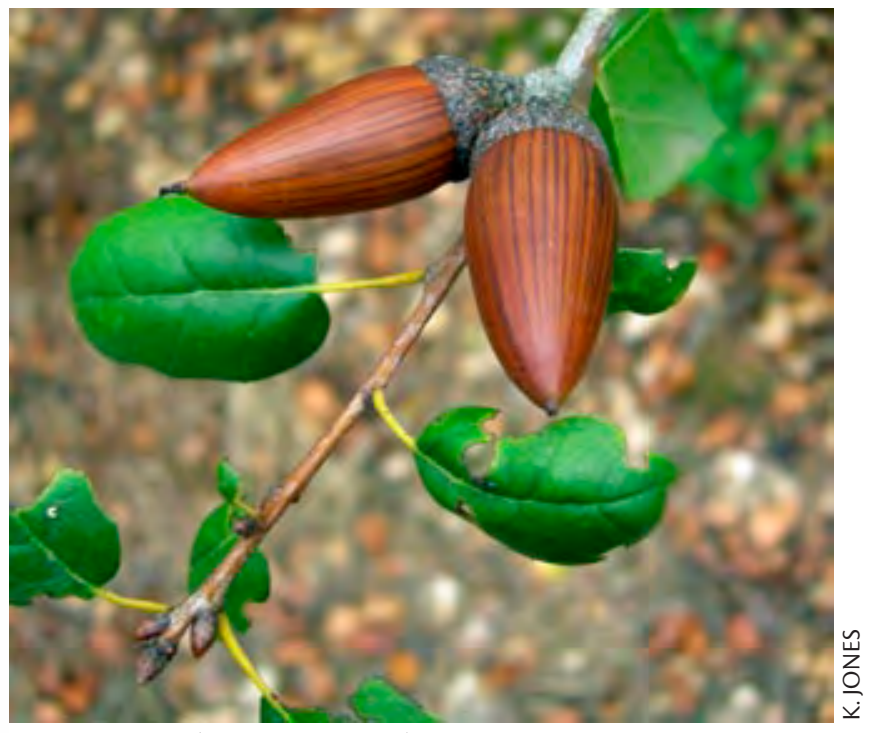

Coast live oak (Quercus agrifolia) acorns. 


\section{Poison Hemlock (Conium maculatum)}

Poison hemlock is often confused with water hemlock because of their similar names and general appearances. Poison hemlock is distinguished by the purple spots on the lower stems of the plant and by different leaves. Both plants have hollow stems and small white flowers arranged in an umbrella-like cluster. The leaves of poison hemlock look somewhat like parsley or wild carrot and give off a disagreeable mousy order. The plants grow 3 to 6 feet tall. Poison hemlock is poisonous to all classes of livestock and to humans as well. Livestock seem to eat it most frequently in the early part of the growing season. It is found in low waste places on dry or moist (but not saturated) fertile ground, generally below 5,000 feet. Poison hemlock loses its toxicity when dried, but caution is warranted when large amounts are found in hay. Ensiling does not reduce the toxicity of poison hemlock.

\section{Signs of poisoning and treatment}

Signs of poisoning develop 1 or 2 hours after exposure and include nervousness, trembling, and weakness (especially of the hind limbs). Animals have a weak pulse and irregular heart rate, lie down, and may become comatose prior to death. Poison hemlock can also cause birth defects in cattle, goats, and pigs, similar that caued by lupines. Prognosis is poor in affected animals. The plant may be killed by herbicides if treated before it begins to bud.

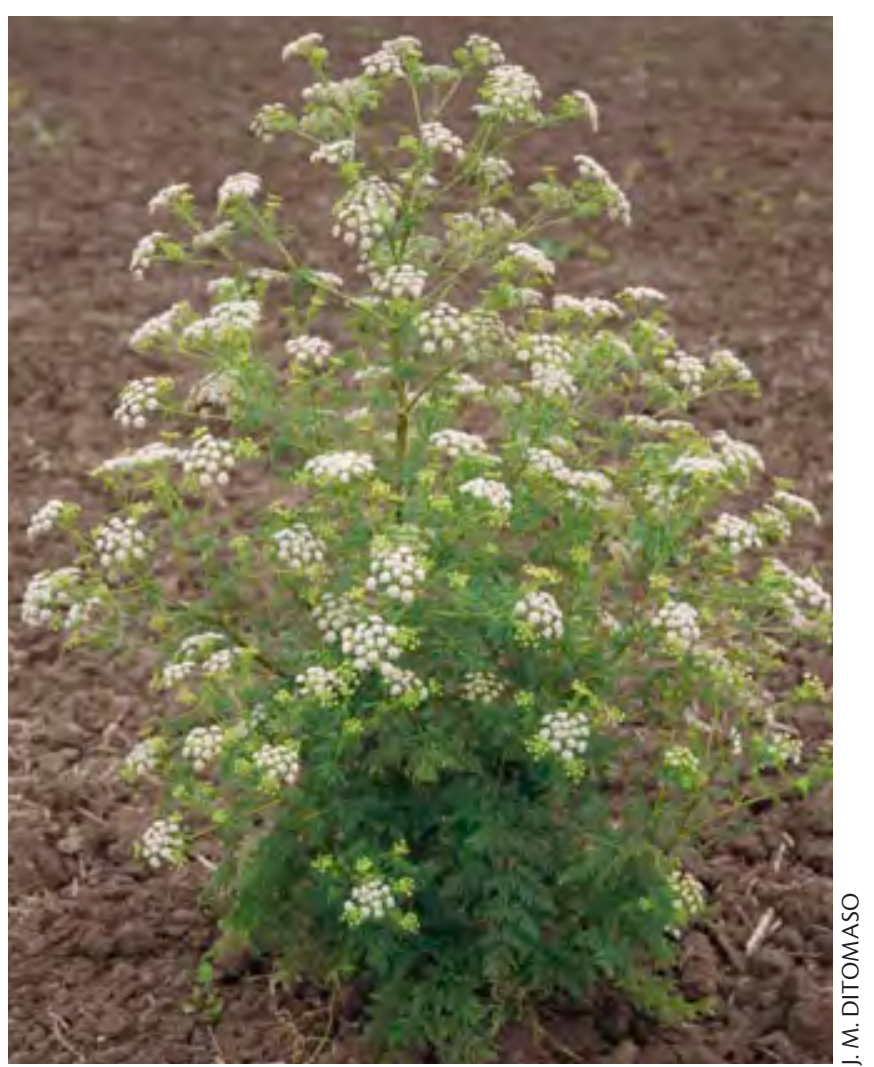

Poison hemlock (Conium maculatum) plant.

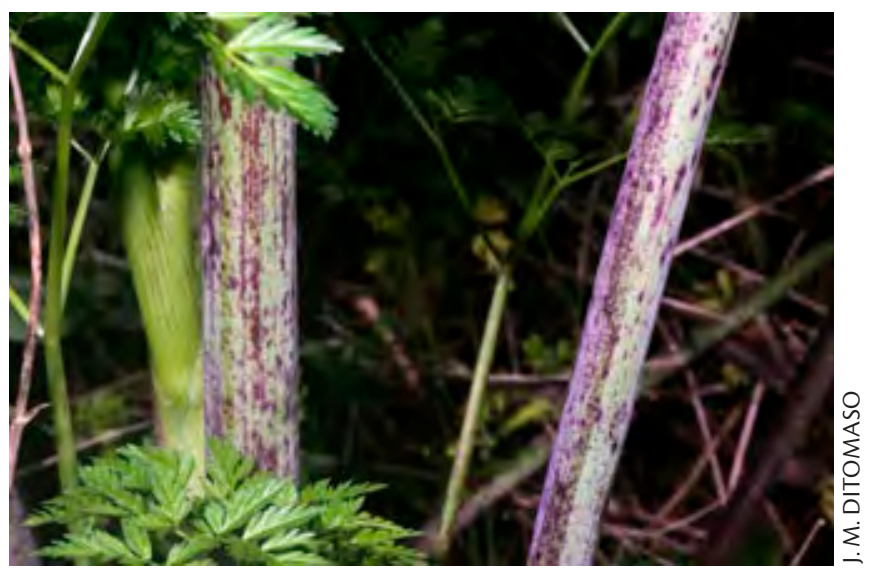

Poison hemlock (Conium maculatum) stem with purple blotches. 


\section{Ponderosa Pine (Pinus ponderosa)}

Consumption of Ponderosa pine needles can cause late-term (last trimester) abortions in cattle. The abortions are caused when cows eat green pine needles from trees, windfalls, or from the ground. Lodgepole pine (P. contorta) and common juniper (Juniperus communis) can contain the same toxin and can also cause abortions.

\section{Signs of poisoning and treatment}

The needles contain a toxin that restricts the blood flow to the placenta, leading to abortion in 2 to 21 days after exposure. The greatest risk is in the last 3 months of pregnancy. Reported intakes to cause abortion are 5 to 6 pounds of pine needles per day for more than 3 days; abortion rates can range from 0 to 100 percent. Before the abortion occurs, a bloody mucous discharge from the vulva may be observed. Cows usually retain the placenta after aborting and may not have sufficient milk production. Weak calves should be checked to make sure that they receive enough milk. Cows may require treatment for the retained placenta. Management strategies to reduce the chance for abortion or weak calves include removing cows from pastures that have ponderosa pine trees during the last trimester of pregnancy, fencing areas that have ponderosa pine, and cutting down trees. Making sure that cows have enough roughage or feed during snow or rain storm significantly decreases the risk of poisoning.

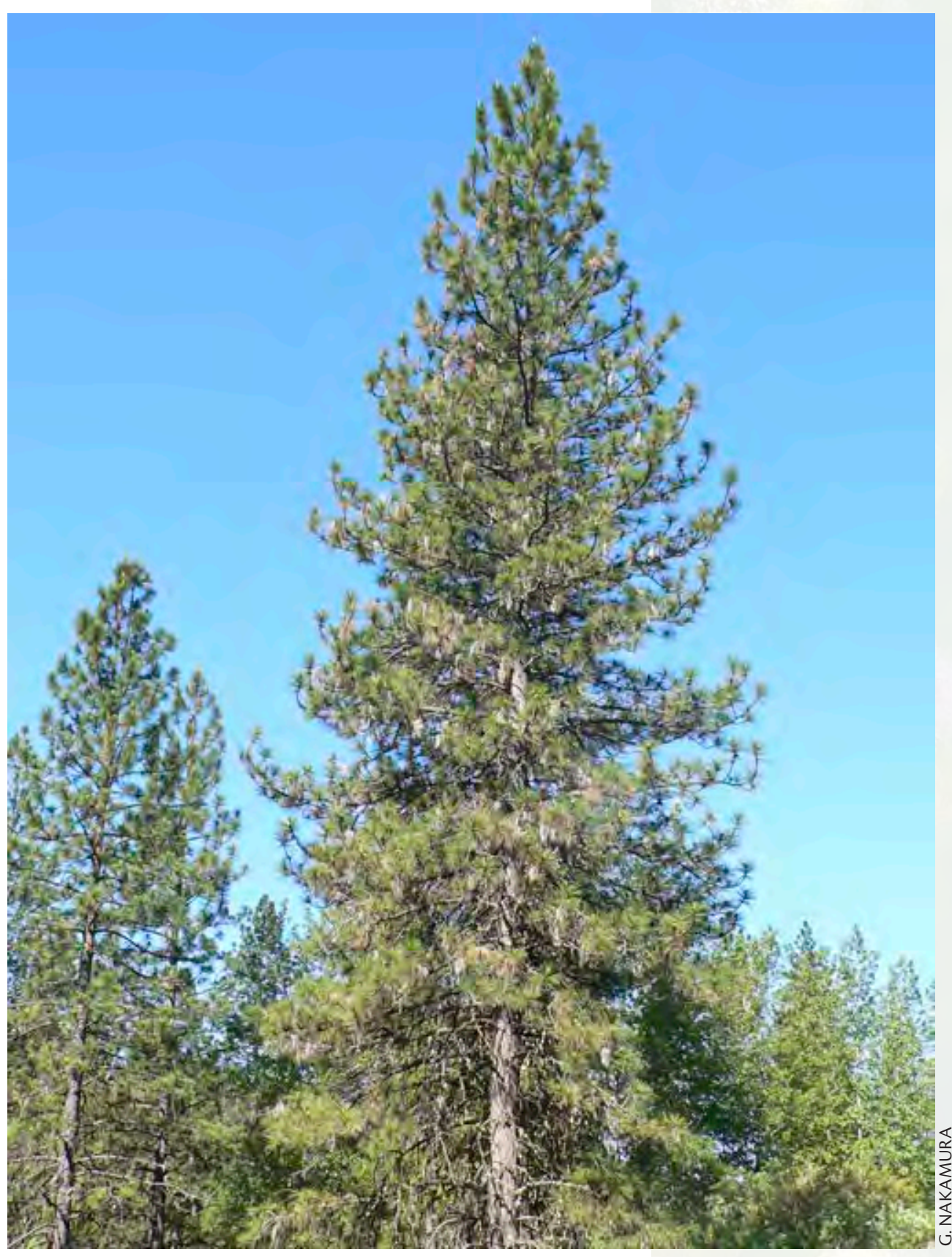

Ponderosa pine (Pinus ponderosa) 


\section{Ryegrass (Lolium spp.) and Dallisgrass (Paspalum dilatatum)}

Ryegrass "staggers" can affect sheep, cattle, and sometimes horses. In California, it is diagnosed most frequently in sheep. Both ryegrass and dallisgrass staggers are caused by a toxin produced by fungal growth on seed heads rather than the plants themselves. Ryegrass is well adapted to the North Coast climate of California, where it is a common component of pastures. In certain locations, however, there is a recurrent problem with ryegrass staggers in the late summer when an endophytic fungus (Neotyphodium lolii) produces tremorgenic mycotoxins (lolitrems). Similar signs occur with dallisgrass in the Central Valley on irrigated pastures or in the fall when continuous rain occurs while seed heads are present and become infected by the ergot-like fungus Claviceps paspali. Rather than flat-looking seeds on the heads, infected heads have gray to black swellings that have a sticky sap material on them.

\section{Signs of poisoning and treatment}

Affected animals show neurological signs including trembling and incoordination and may sometimes show aggressive behavior. Signs of ryegrass staggers are greatly aggravated when animals are stressed. Poisoned animals that are stressed or excited will start running but then develop tremors and fall down. In severe poisonings, animals go down and remain down for several days. Convulsions and death can occur in extreme cases. Affected ewes may have drastically reduced milk production after lambing. Remove animals from infested pasture and provide clean feed. In mild cases of staggers, animals are best left undisturbed or shifted quietly without a dog to a safer paddock with trough water instead of being left in a field with open water that they might fall into and drown. Drifting animals through an open gate rather than driving might be necessary in more severe cases. Some operators leave gates open in the pasture and feed hay in another area to allow the animals to move from the pasture on their own. Animals that are severely affected and unable to stand must be provided with adequate feed and water.

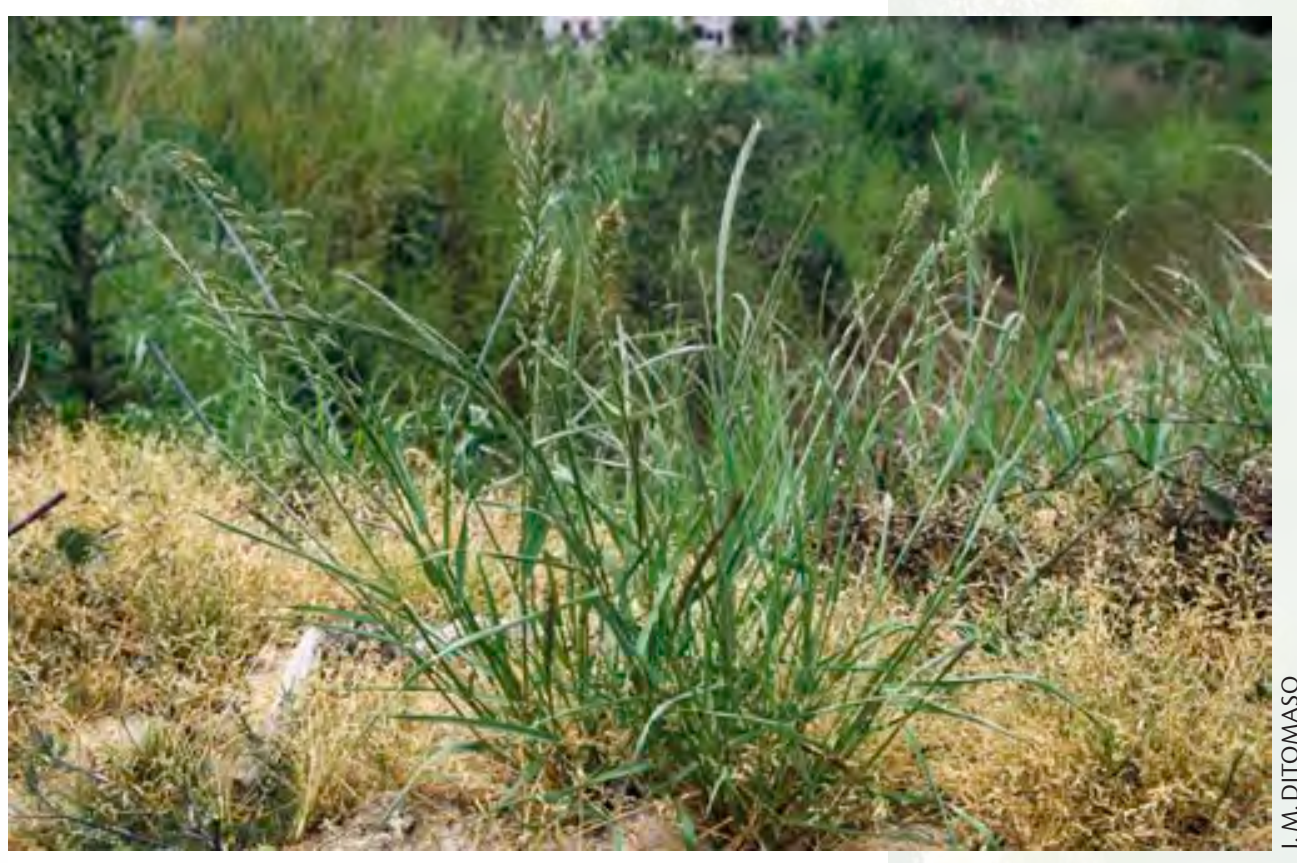

Perennial ryegrass (Lolium perenne) plant.

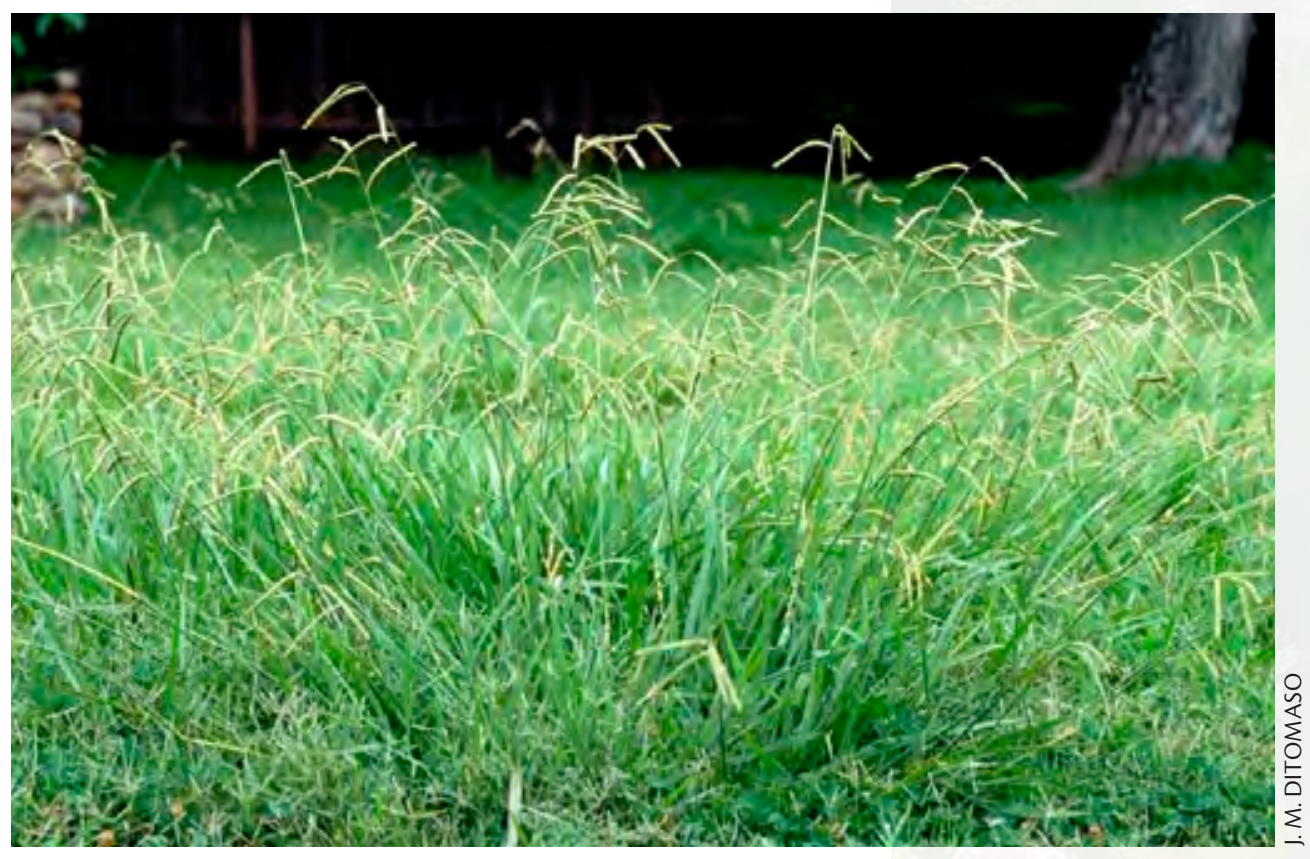

Dallisgrass (Paspalum dilatatum) plant. 


\section{Starthistle (Centaurea spp.)}

Yellow starthistle (Centaurea solstitialis) and purple starthistle (C. calcitrapa) are members of the large and diverse sunflower family. An annual weed, starthistle is branched from the base and grows to $2^{1 / 2}$ feet tall. The flowers grow out of a spiny enclosure. The leaves and stems are densely covered with fine hairs. Yellow starthistle is widely distributed in California, with poisonings reported in the Central Valley and coastal and Sierra foothill areas below 5,000 feet. It is often a weed of hayfields, where it is a cause for concern. Horses, donkeys, and mules are the only animals poisoned by the plant. Affected animals may acquire a taste for the plant and eat it even when it is mature and thorny. The plant is poisonous throughout the year, but two peaks in poisoning have been observed in California, from June to July, and from October to November. A horse must consume more than 600 pounds of the plant over a period of 30 to 45 days before poisoning develops.

\section{Signs of poisoning and treatment}

Signs of Centaurea species poisoning are distinctive in horses and have been termed "chewing disease." An affected horse will show continuous chewing movements, frothing of saliva, difficulty eating, frequent yawning, and an open mouth with a protruding tongue. When attempting to drink, affected horses submerge their heads deeply into water buckets and then tip their heads back. Abnormal curling of the lips or tongue may also be seen. Once horses show these clinical signs, they do not recover from the disease and will die.

It is important to recognize the specific signs and the characteristic spiny flower heads in hay or pasture. The weed may be controlled by the application of an appropriate herbicide, if practical given the size of the infestation. No effective treatment for poisoned animals is known. An infested pasture may be safely grazed by classes of livestock other than horses, if forage is sufficient.

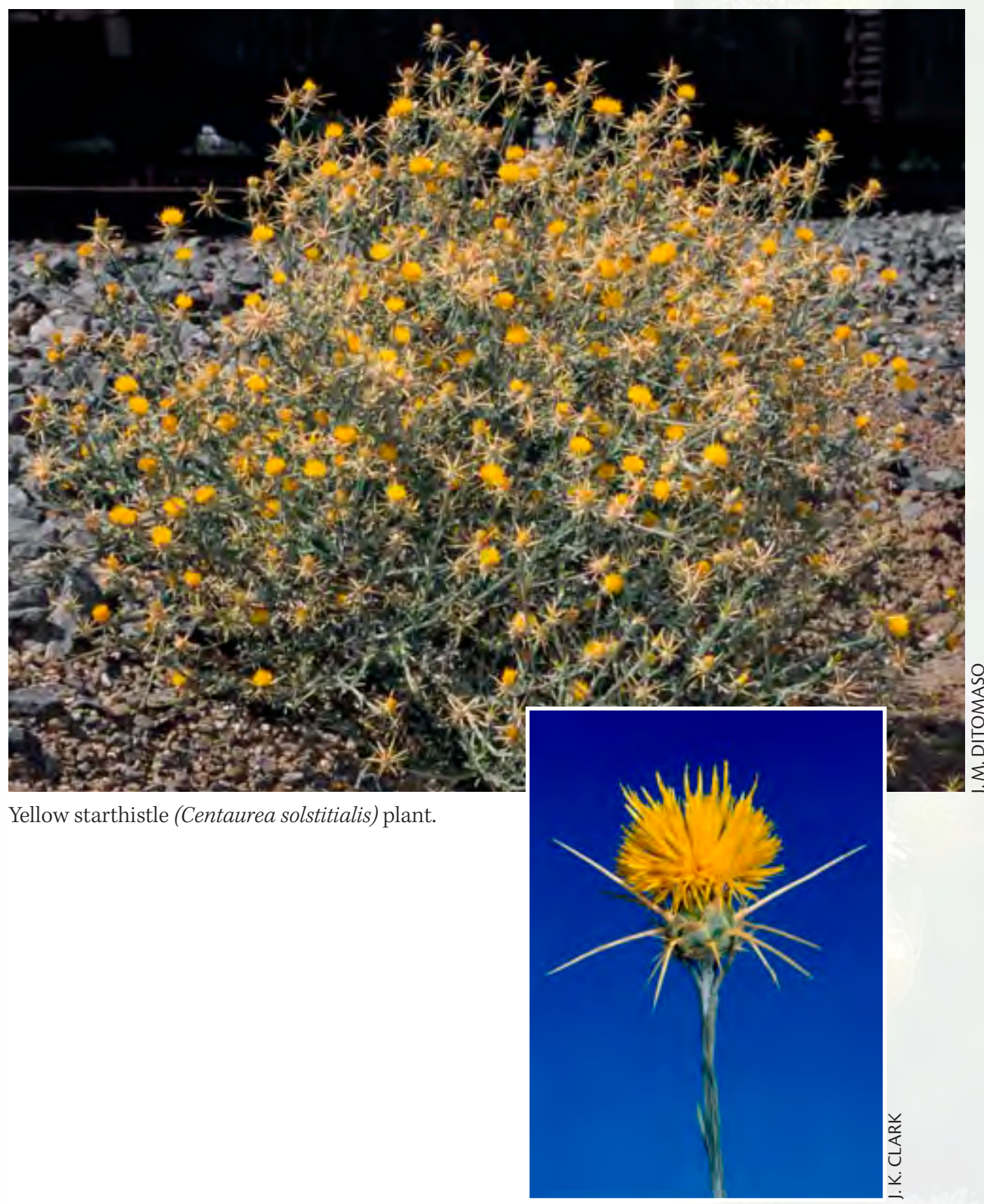

Yellow starthistle (Centaurea solstitialis) flowering head. 


\section{Summer Pheasant's Eye (Adonis aestivalis)}

Summer pheasant's eye is a plant in the buttercup family that was introduced into North America as a horticultural plant but escaped cultivation and is now naturalized in the western United States. It is well established in some Northern California counties and has been found as a contaminant in alfalfa and grass hay. The stems of summer pheasant's eye have linear ridges, the leaves are feathery, and the flowers have waxy, orange petals. Summer pheasant's eye is considered unpalatable, which is most likely why reports of poisoning are rare.

\section{Signs of poisoning and treatment}

The toxins in summer pheasant's eye and the signs of poisoning are similar to those of oleander. Leaves and flowers have the highest concentrations of toxins. In addition to cardiac toxicity, horses poisoned with summer pheasant's eye develop gastrointestinal disturbances such as colic, hemorrhagic enteritis, diarrhea, or decreased gut motility. Acute and chronic feeding studies conducted in cattle and sheep indicated that these animals are much less susceptible to summer pheasant's eye than are horses.

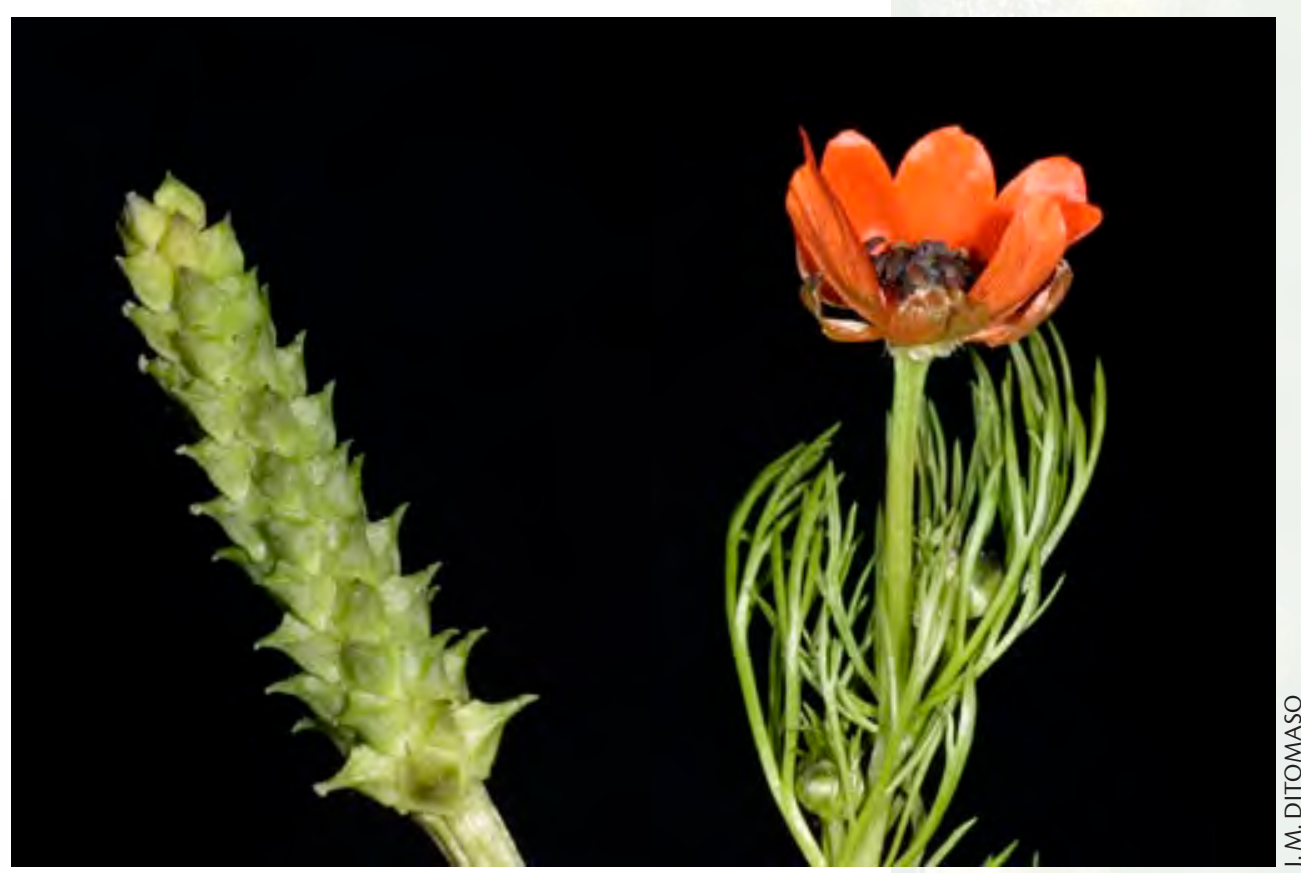

Summer pheasant's eye (Adonis aestivalis) flower and fruit. 


\section{Tobacco (Nicotiana spp.)}

Three toxic species of tobacco occur in California. Two species (desert tobacco, N. trigonophylla, $N$. obtusifolia, and coyote tobacco, $N$. attenuata) are usually strongly scented, hairy, and sticky shrubs with cream or greenish white trumpet-shaped flowers. Tree tobacco ( $N$. glauca) is distinguished from these other two by its shrubby, taller growth habit of 5 to 20 feet, yellow flowers (also trumpet-shaped), and nonhairy bluish green leaves, which are often covered with a waxy, whitish bloom, like a cabbage leaf. Wild tobaccos are plants of waste places or flood plains, often on sandy or rocky soil. A Nicotiana species occurs in almost every county of California. Plants are poisonous to all classes of livestock and to humans, but they are generally unpalatable and are eaten only if other forage is not available.

\section{Signs of poisoning and treatment}

Signs of acute poisoning are very similar to poison hemlock poisoning and include shaking, twitching, staggering, paralysis, convulsions, heavy breathing, coma, and death. Affected animals may also show excessive salivation and diarrhea, which is often followed by constipation. Death is usually rapid. Tobacco can produce birth defects similar to those caused by lupine and poison hemlock in cattle, sheep, goats, and pigs. Because Nicotiana species are unpalatable, provision of ample forage is the best way to prevent poisoning.

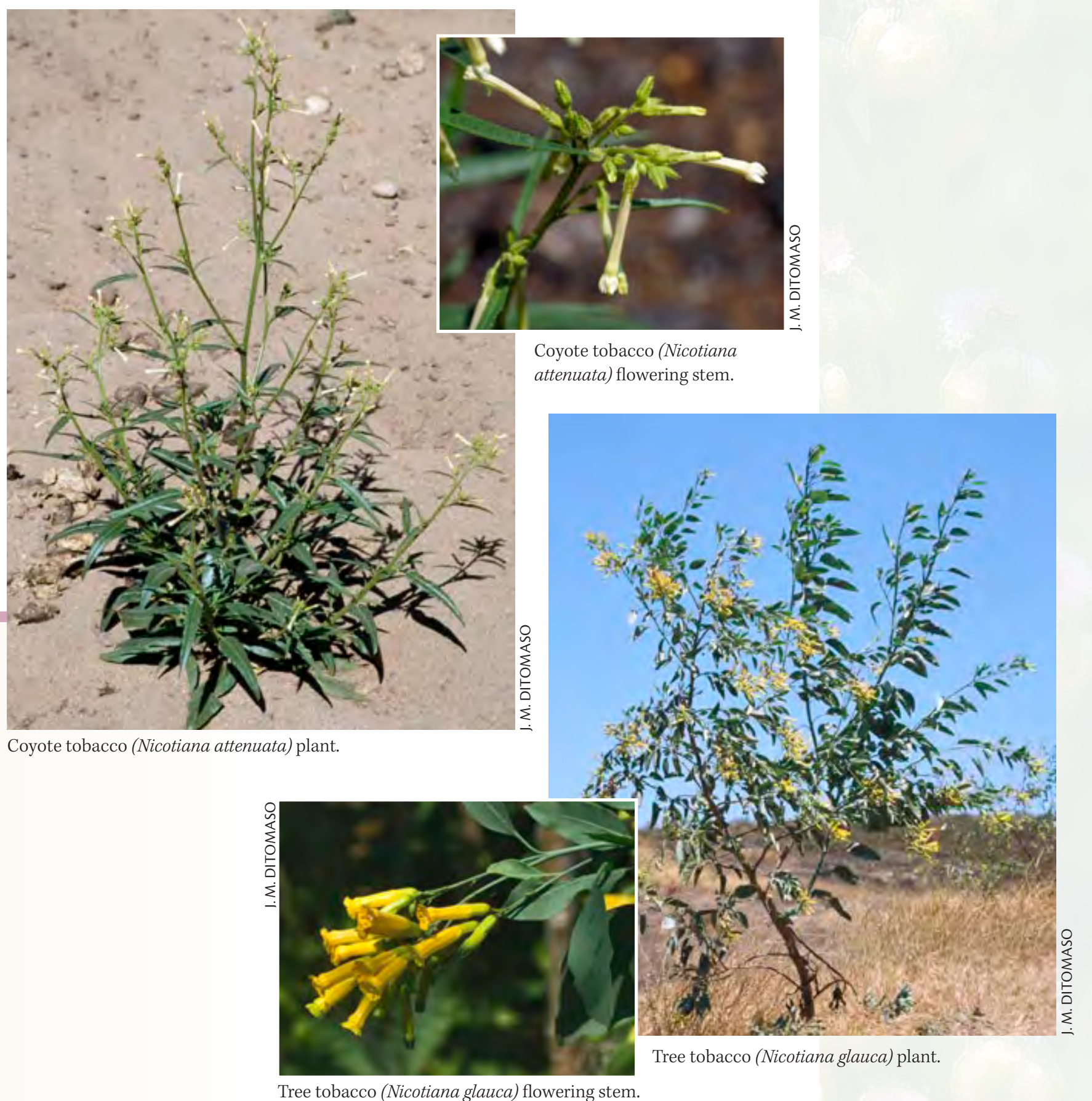




\section{Toyon (Heteromeles arbutifolia)}

Toyon is also known as tollon, Christmas holly, or Christmas berry. The plant is a native evergreen shrub or tree with bright red fruit in the winter. Although it is native to California and Baja California, toyon is also widely planted as an ornamental. Its natural habitat includes chaparral, oak and conifer woodlands, and mixed-evergreen forests up to 3,300 feet elevation. The plant is also used as a Christmas decoration.

\section{Signs of poisoning and treatment}

The toxic compounds in toyon are the same as those in arrowgrass, thus the signs and treatment are identical. Toyon poisoning has killed goats that were offered fresh clippings. In order to prevent toyon poisoning, animals should not be offered toyon clippings or have access to toyon in their environment.

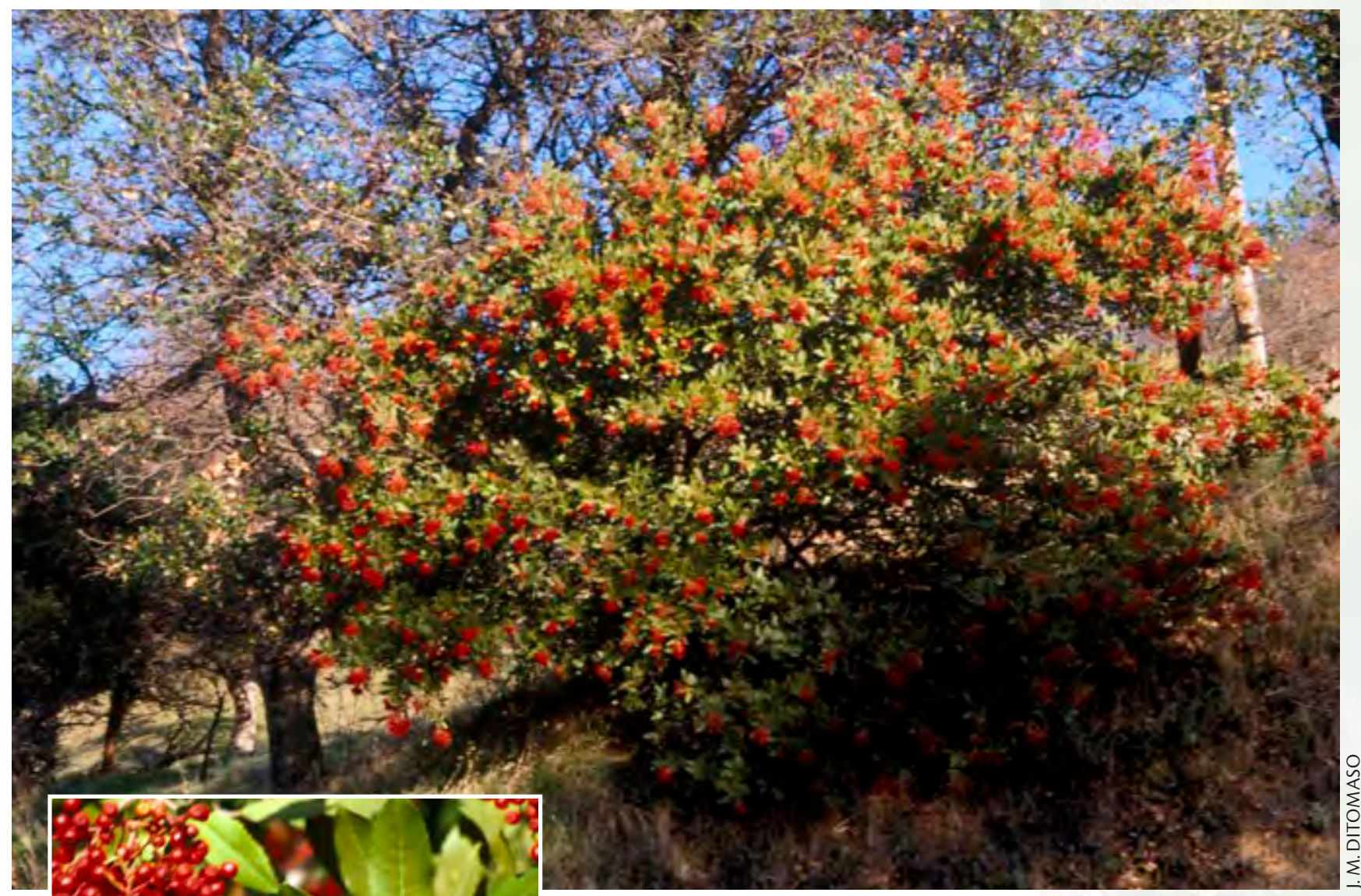

Toyon (Heteromeles arbutifolia) plant.

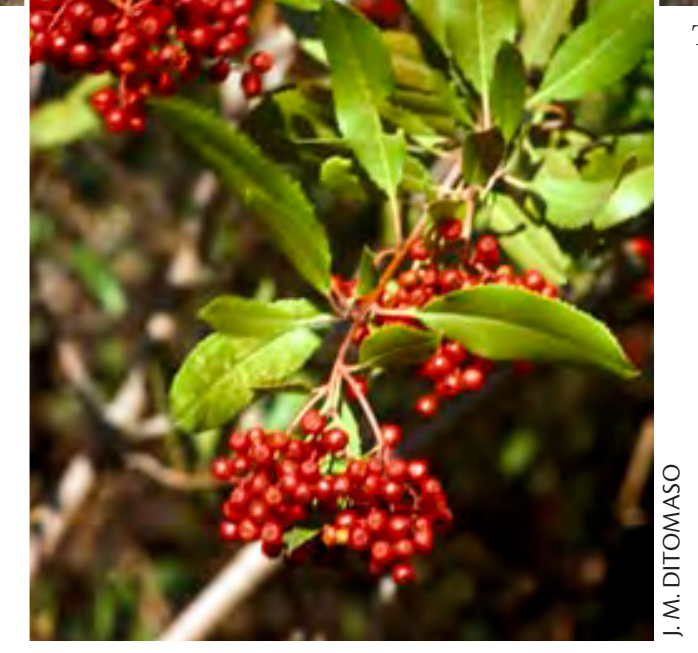

Toyon (Heteromeles arbutifolia) flowering stem. 


\section{Veratrum, False Hellebore, or Corn Lily (Veratrum californicum)}

Veratrum, a common plant of wet mountain meadows, is characterized by large parallel-veined boat-shaped leaves. The cream-colored or greenish yellow flowers appear in July or August and are borne in branched clusters atop an unbranched stalk, giving the plant an appearance similar to a tasseling corn plant. Veratrum grows in moist swamps and meadows from sea level to 11,000 feet in the Sierra, northern Coast Ranges, and the higher mountains of Southern California. The plant is poisonous at all stages of growth; the roots are more toxic than the stem or leaves. Sheep and goats commonly eat the plant, while cattle will eat it only if other forage is scarce.

\section{Signs of poisoning and treatment}

The highest concentrations of the toxin occur in leaves from June to early July, while roots contain the highest concentrations in August. The toxins cause birth defects and also affect the brain. Birth defects are most commonly seen in sheep, but cattle, goats, llamas, and horses are also susceptible. Lambs born to pregnant ewes that ingest veratrum on day 14 of gestation will have cyclops ("monkey-face," with a single eye). Exposure of pregnant sheep to veratrum on days 19 through 21 of gestation may result in embryonic death and, on days 28 to 32 , in limb defects. While animals rarely ingest large enough amounts of veratrum to develop neurologic signs, 2 to 3 hours after an animal has eaten a large dose signs will include slowed heartbeat, low blood pressure, labored breathing, salivation, vomiting, and convulsions. It is important to limit access to veratrum, especially during the first trimester of pregnancy. Frost reduces the toxicity of the plant, making animals much less at risk.

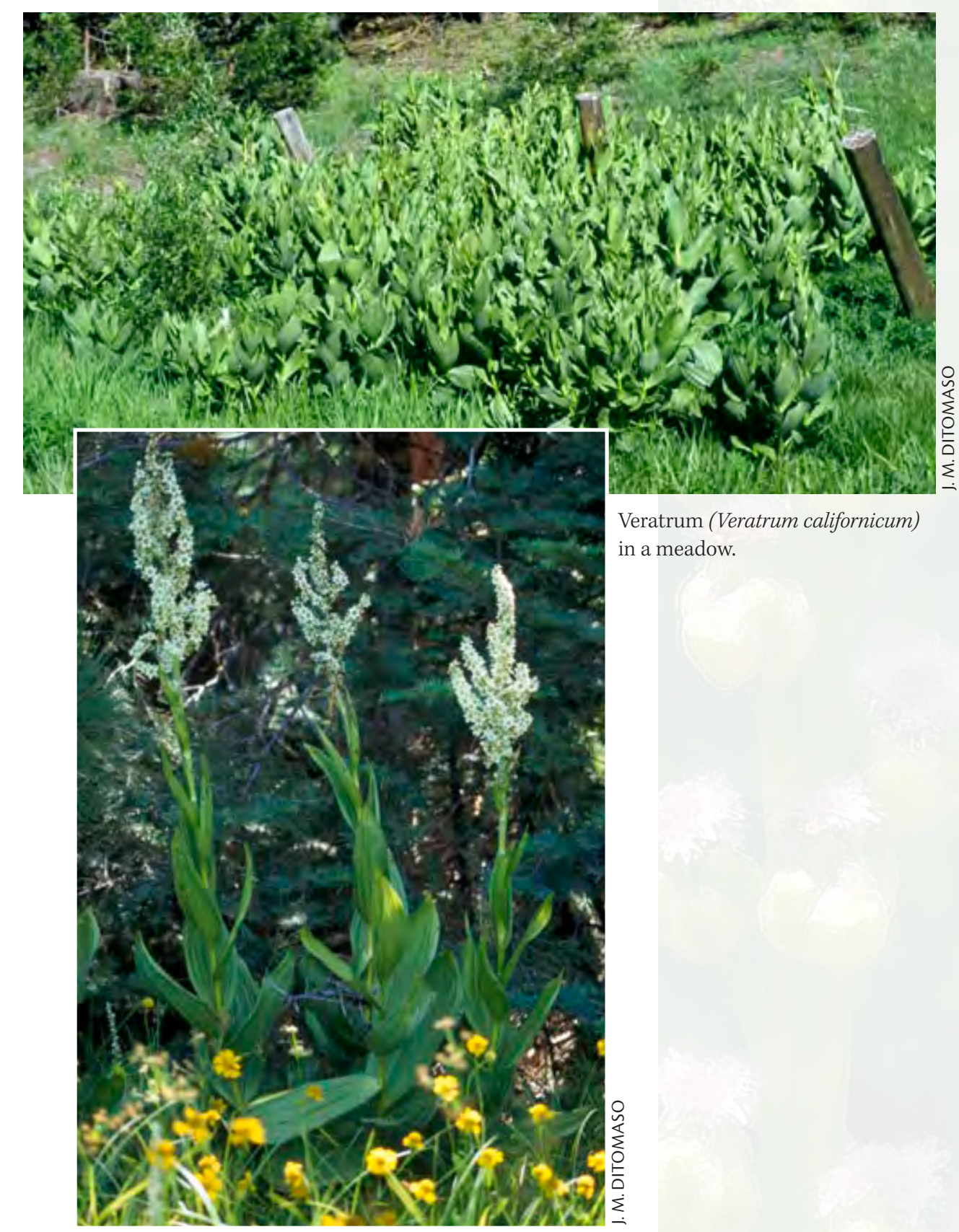

Veratrum (Veratrum californicum) plants. 


\section{Water Hemlock (Cicuta douglasii and C. maculata)}

Water hemlocks are among the most poisonous plants in North America. They are poisonous to all classes of livestock and also to humans. Water hemlocks, like other members of the carrot family, bear small white flowers in umbrella-shaped clusters and grow to 9 feet tall. They have a hollow, freely branching stem with a series of partitions at the base that may contain a yellow fluid. The chambered, tuberous root is characteristic and contains the highest concentration of toxin. Water hemlocks may be distinguished from poison hemlock by their leaves, which have distinct leaflets compared with the more branching, dissected leaves of poison hemlock. Water hemlocks grow in wet, marshy places and along streams in most of California. Plant tops are seldom eaten; most cases of poisoning occur when an animal eats the root. Newly emerging plants in the spring are most toxic, while mature leaves and dry stems are minimally toxic. However, all parts of the plant are considered toxic.

\section{Signs of poisoning and treatment}

Signs of poisoning occur suddenly, usually within half an hour of ingestion, and include convulsive seizures, lying down, incoordination, salivation, and vigorous chewing movements. Death usually occurs 1 to 3 hours after exposure. The lethal dose of fresh roots is 2 ounces for sheep, 1 to 12 ounces for cattle, and 8 ounces for horses. Treatment is rarely possible because of the acute onset and rapid progression. Diligent removal of water hemlock from areas to which animals have access is critical to prevent poisonings. Plants should be dug up and burned, because the rootstalks remain poisonous when dead. If chemical control measures are used, animals must be kept from the treated area because sprayed, wilted plants are more palatable to livestock.

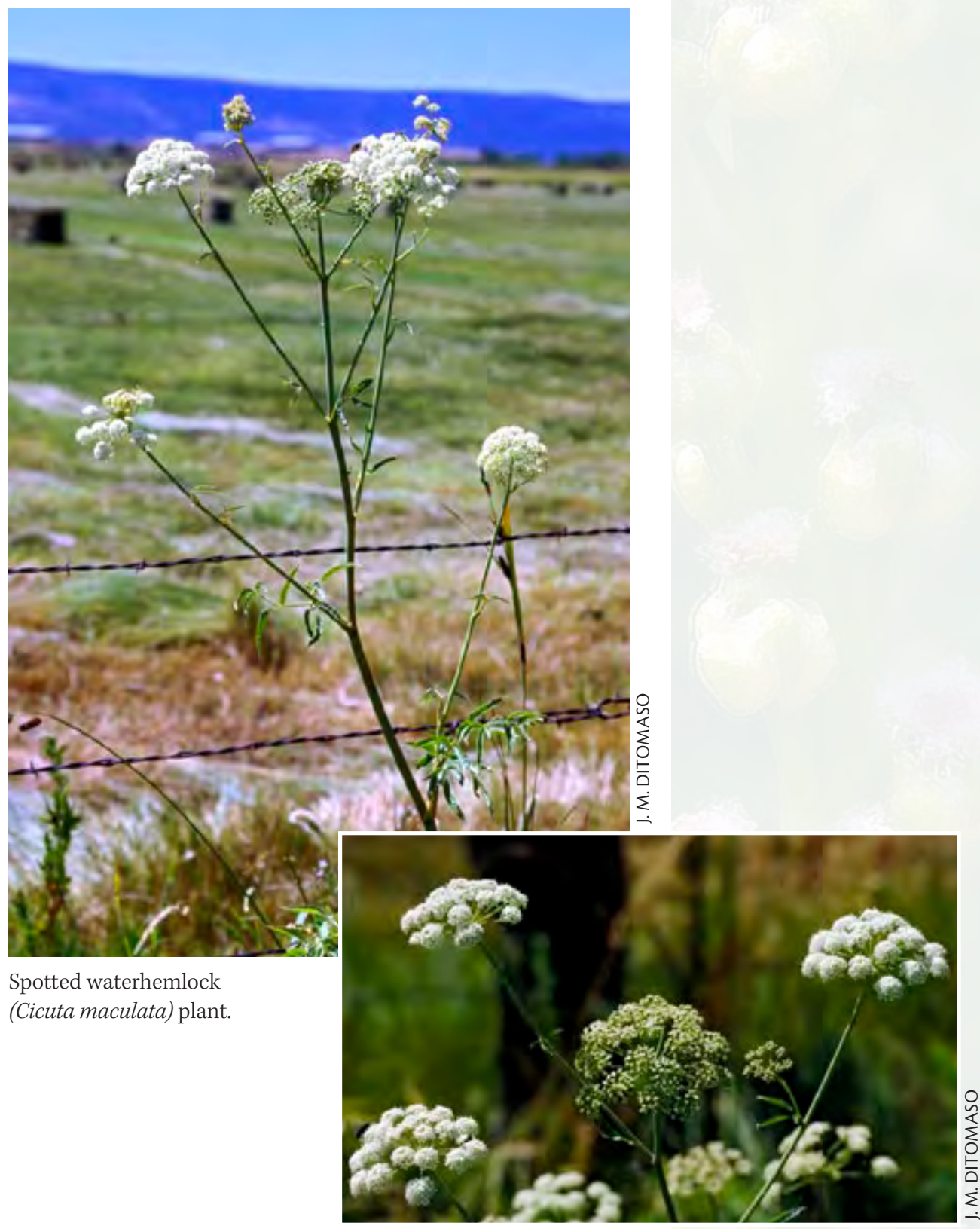

Spotted waterhemlock (Cicuta maculata) flowering stems. 


\section{Western Azalea \\ (Rhododendron occidentale)}

Both landscape and native Rhododendron species have woody, evergreen or deciduous shrubs. The simple leaves alternate on either side of the stem, and are smooth or toothed margined. Flowers are borne in a terminal cluster and are tubular, 5-parted, and white to deep pink or yellow. The fruit is in an elongated capsule.

\section{Signs of poisoning and treatment}

Signs of poisoning include salivation, decreased heart rate, nausea, weakness, difficulty breathing, progressive paralysis, and coma. Vomiting may also be seen in goats.

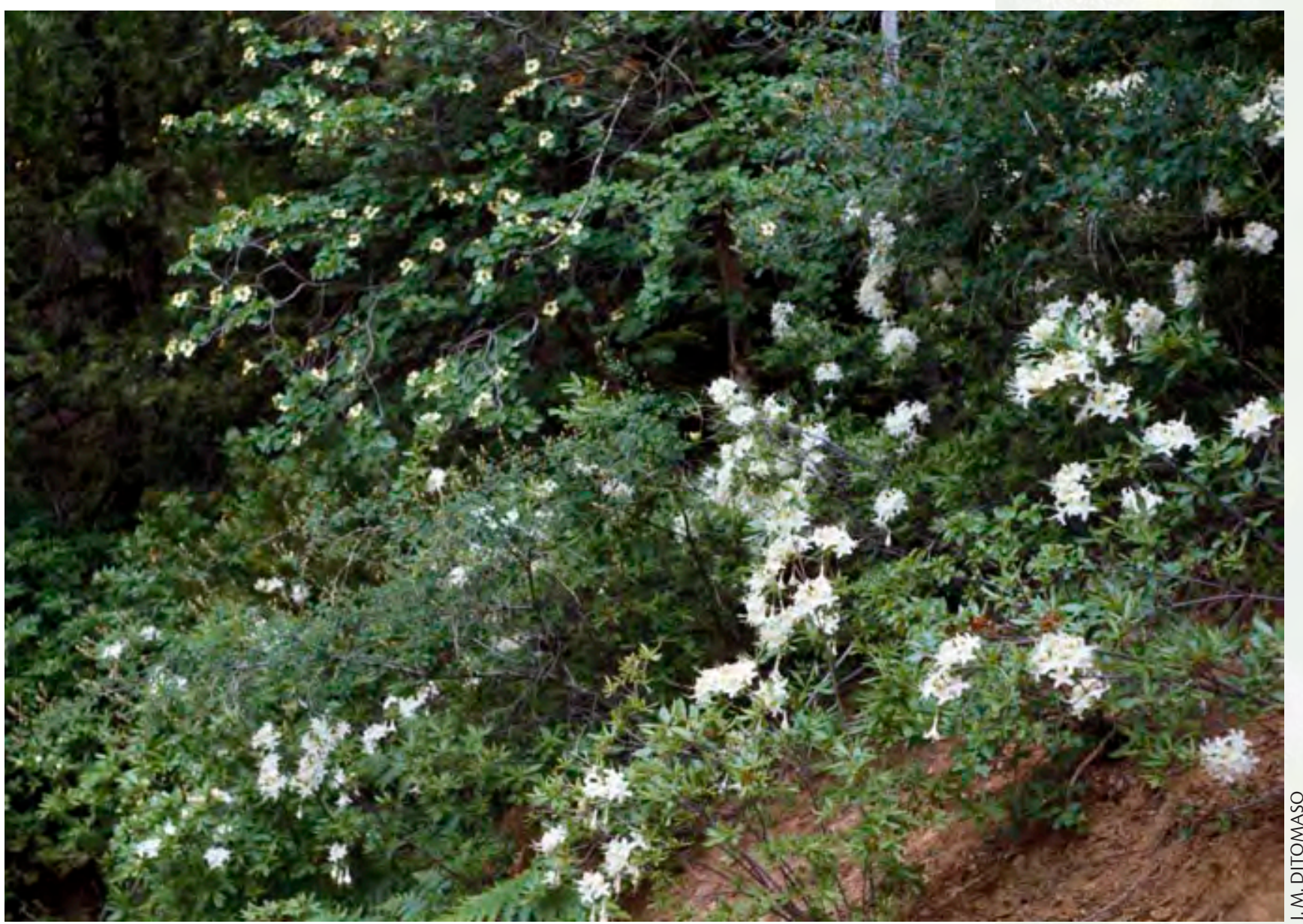

Western azalea (Rhododendron occidentale) plant. 


\section{Western Bracken Fern (Pteridium aquilinum)}

The widespread western bracken fern (Pteridium aquilinum) is characterized by broad triangular fronds (leaves) with several divisions (bipinnately compound). The edges of the leaflets are rolled under, and in mature fronds the rolled-up edges harbor the brown spore-bearing organs. The fronds arise from a black, creeping, woody underground root system. Western bracken fern is widely distributed in California and is commonly found in moist, open woodlands along pasture edges, in logged areas, and along roadsides. Both green and dried plants are toxic, with the root rhizome (underground stem) being most toxic. Cattle and horses are most frequently poisoned, but sheep and pigs can also be affected.

\section{Signs of poisoning and treatment}

Western bracken fern contains a variety of toxins, principally thiaminase, an enzyme that causes the breakdown of vitamin B1 (thiamine), leading to thiamine deficiency. Severe thiamine deficiency can occur in horses that have consumed a diet containing 3 to 5 percent western bracken fern for at least 30 days. Signs include central nervous system depression, blindness, feed refusal, weight loss, depression, muscle tremors, uncoordinated gait, colic, constipation, seizures, and lying down. Treatment includes the administration of thiamine. Ruminants can produce thiamine in the rumen, so they are not seriously affected by this toxin. Another toxin in western bracken fern is a cancer-causing compound that can lead to bone marrow depression. This compound is excreted in milk and thus presents a risk for humans and nursing animals. In cattle, western bracken fern exposure for more than 1 to 2 months can lead to the development of an acute syndrome characterized by bleeding from nose, mouth, and vagina, blood in feces, blood in urine, and high mortality. Additionally, western bracken fern may cause tumors in the bladder in cattle primarily 3 to 4 years of age. Sheep can develop an acute syndrome similar to what has been described for cattle and "bright blindness," an irreversible retinal degeneration. Intoxication from western bracken fern is most commonly observed in the fall when other forage is depleted. Occurrence of western bracken fern in hayfields is cause for concern. Poisoning in horses is seen most often when hay containing 20 percent or more of western bracken fern is fed. The plant may be eradicated where feasible by cultivating the soil for 2 to 3 years or mowing the tops early in the season. Complete eradication usually takes 3 years. Supplemental feeding at the end of the grazing season to compensate for decreased forage value can also help reduce losses due to poisoning by western bracken fern. Western brackenf
aquilinum) frond.

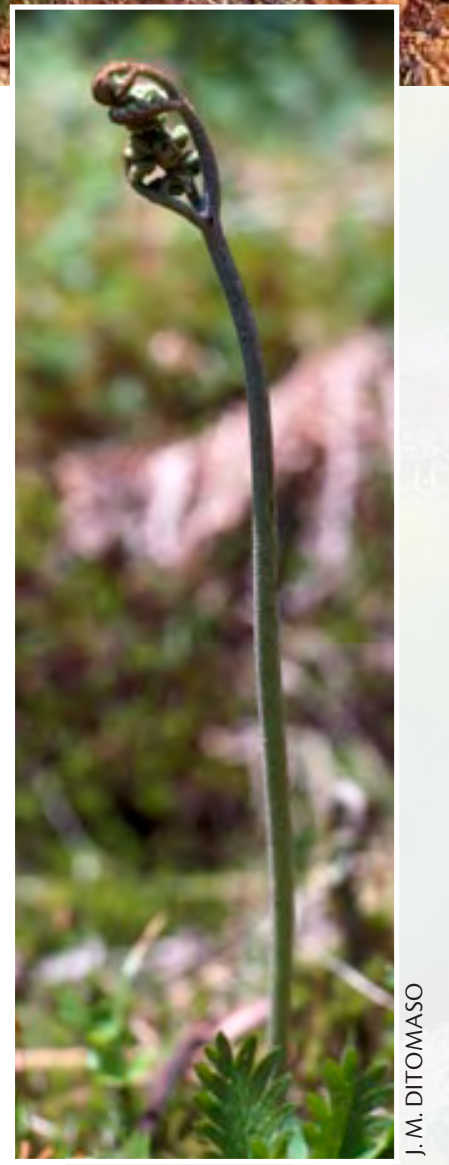

Western bracken fern (Pteridium aquilinum) developing frond. 


\section{Nitrate Accumulators}

A number of common crop and pasture plants and weeds can accumulate toxic concentrations of nitrate. Among the weeds, pigweeds (Amaranthus spp.), lambsquarter or goosefoots (Chenopodium spp.), and nightshades (Solanum spp.) have been found to contain nitrate at potentially toxic concentrations. Among crop plants, oat hay, corn, and sorghum have especially been associated with nitrate toxicosis, and alfalfa can also contain potentially toxic nitrate concentrations. Conditions such as heavy fertilization of pastures, herbicide application, drought, cloudy weather, and decreased temperature yield increased concentrations of nitrate in plants. In addition, nitrate accumulates in the vegetative tissue, creating the highest concentrations in the lower stalks and stems. Leaf material and grain or seeds generally do not contain toxic nitrate levels. Forage nitrate levels of 0.3 percent $(3,000 \mathrm{ppm})$ and above are potentially dangerous, with acute poisoning likely to occur if the nitrate level exceeds 1 percent (10,000 ppm).

\section{Signs of poisoning and treatment}

Ruminants and pseudoruminants (e.g., llamas and alpacas) are very susceptible to nitrate poisoning. Signs of acute nitrate poisoning in ruminants are caused by a reduction in the oxygen-carrying capacity of the blood. Nitrate causes the formation of methemoglobin, which sometimes makes the blood a dark brown or chocolate color. Poisoned animals become depressed, have difficulty breathing, and develop tremors, incoordination, rapid heartbeat, and convulsions. Death may occur within 6 to 24 hours of ingestion. Diagnosis is based on laboratory analysis of nitrate and nitrite in serum, blood, ocular fluid, rumen contents, and forage. While drying does not alter the nitrate concentration of plants, ensiling of forages results in a large reduction of nitrate within 1 to 2 months. Careful use of nitrogen fertilizers, harvesting under appropriate conditions, supplementating with high-carbohydrate feed, and testing hay and forage for nitrate content are additional approaches to minimize the risk of nitrate poisoning in animals.

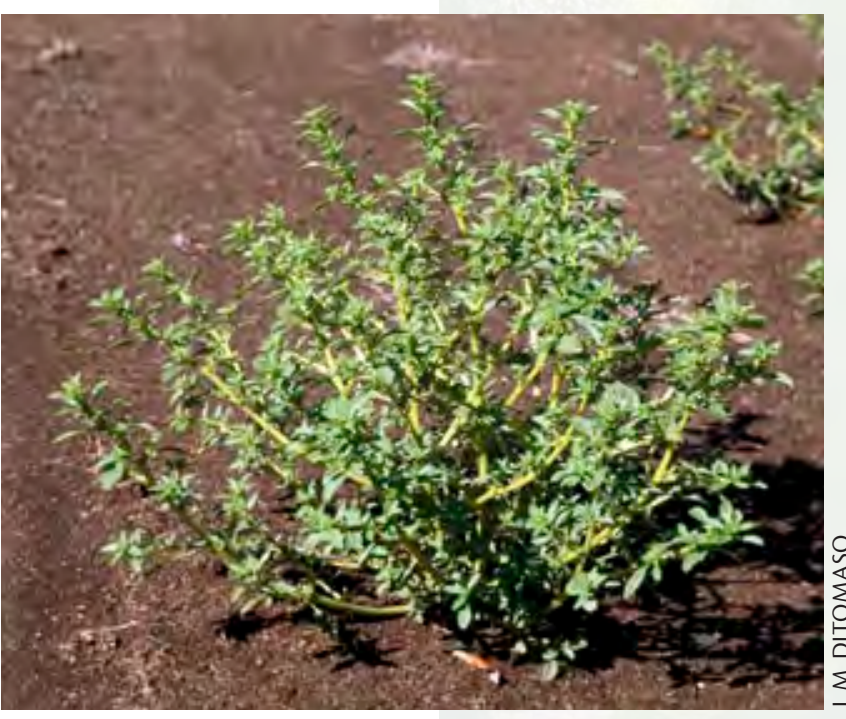

Tumble pigweed (Amaranthus albus) plant.

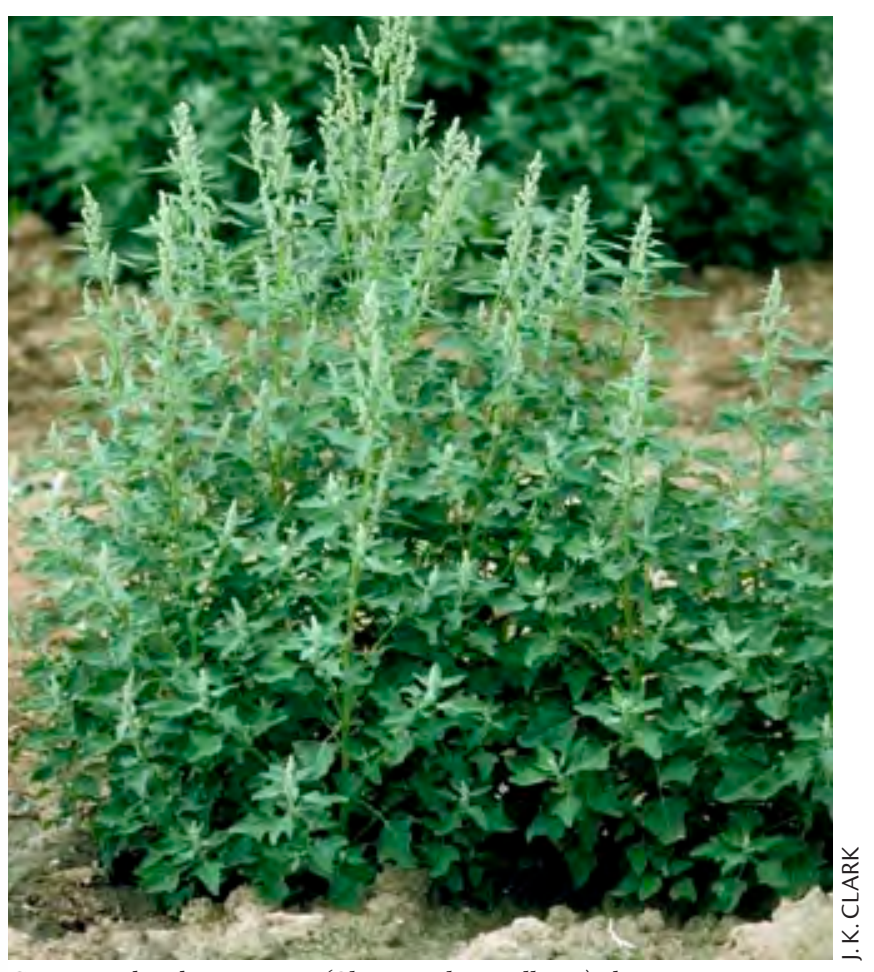

Common lambsquarters (Chenopodium album) plant. 


\section{References}

Burrows, G. E., and R. J. Tyrl. 2001. Toxic plants of North America. Ames: Iowa State University Press.

Fowler, M., A. L. Craigmill, B. B. Norman, and P. Michelsen. 1982. Livestock-poisoning plants of California. Oakland: University of California Division of Agriculture and Natural Resources Leaflet 2168.

Phillips, R. L., J. Karlik, and M. Fowler. 1997. Toxicity of ornamental plants to domestic animals and livestock. Oakland: University of California Division of Agriculture and Natural Resources Publication 21564.

\section{Acknowledgment}

Significant portions of Livestock-Poisoning Plants of California (ANR Leaflet 2168, 1982) are included in this publication. The authors would like to especially recognize Dr. Murray Fowler, Dr. Ben B. Norman, and Dr. Paul Michelsen, authors of ANR Leaflet 2168, for their work.

\section{U.S. Customary-Metric Conversions}

\begin{tabular}{|l|l|l|l|}
\hline U.S. Customary & $\begin{array}{l}\text { Conversion Factor } \\
\text { for U.S. Customary } \\
\text { to Metric }\end{array}$ & $\begin{array}{l}\text { Conversion Factor } \\
\text { for Metric to } \\
\text { U.S. Customary }\end{array}$ & Metric \\
\hline inch (in) & 2.54 & 0.394 & centimeter $(\mathrm{cm})$ \\
foot (ft) & 0.3048 & 3.28 & meter $(\mathrm{m})$ \\
acre (ac) & 0.4047 & 2.47 & hectare $(\mathrm{ha})$ \\
fluid ounce $(\mathrm{fl} \mathrm{oz})$ & 29.57 & 0.034 & milliliter $(\mathrm{ml})$ \\
ounce $(\mathrm{oz})$ & 28.35 & 0.035 & gram $(\mathrm{g})$ \\
pound $(\mathrm{lb})$ & 0.454 & 2.205 & kilogram $(\mathrm{kg})$ \\
ounce per pound $(\mathrm{oz} / \mathrm{lb})$ & 62.5 & 0.016 & gram per kilogram $(\mathrm{g} / \mathrm{kg})$ \\
Celsius $\left({ }^{\circ} \mathrm{C}\right)$
\end{tabular}

Inquiries regarding the University's nondiscrimination policies may be directed to the Affirmative Action/Equa Opportunity Director, University of California, Agriculture and Natural Resources, 1111 Franklin Street, 6th Floor, Oakland, CA 94607, (510) 987-0096. For information about ordering this publication, telephone 1-800-994-8849. For assistance in downloading this publication, telephone 530-754-3927.

An electronic copy of this publication can be found at the ANR Communication Services catalog Web site, http://anrcatalog.ucdavis.edu.

\section{UCY}

This publication has been anonymously peer reviewed for technical accuracy by University of California scientists and other qualified professionals. This review process was managed by the ANR Associate Editor for Animal, Avian, and Aquaculture Sciences.

web-1/11-SB/RW 